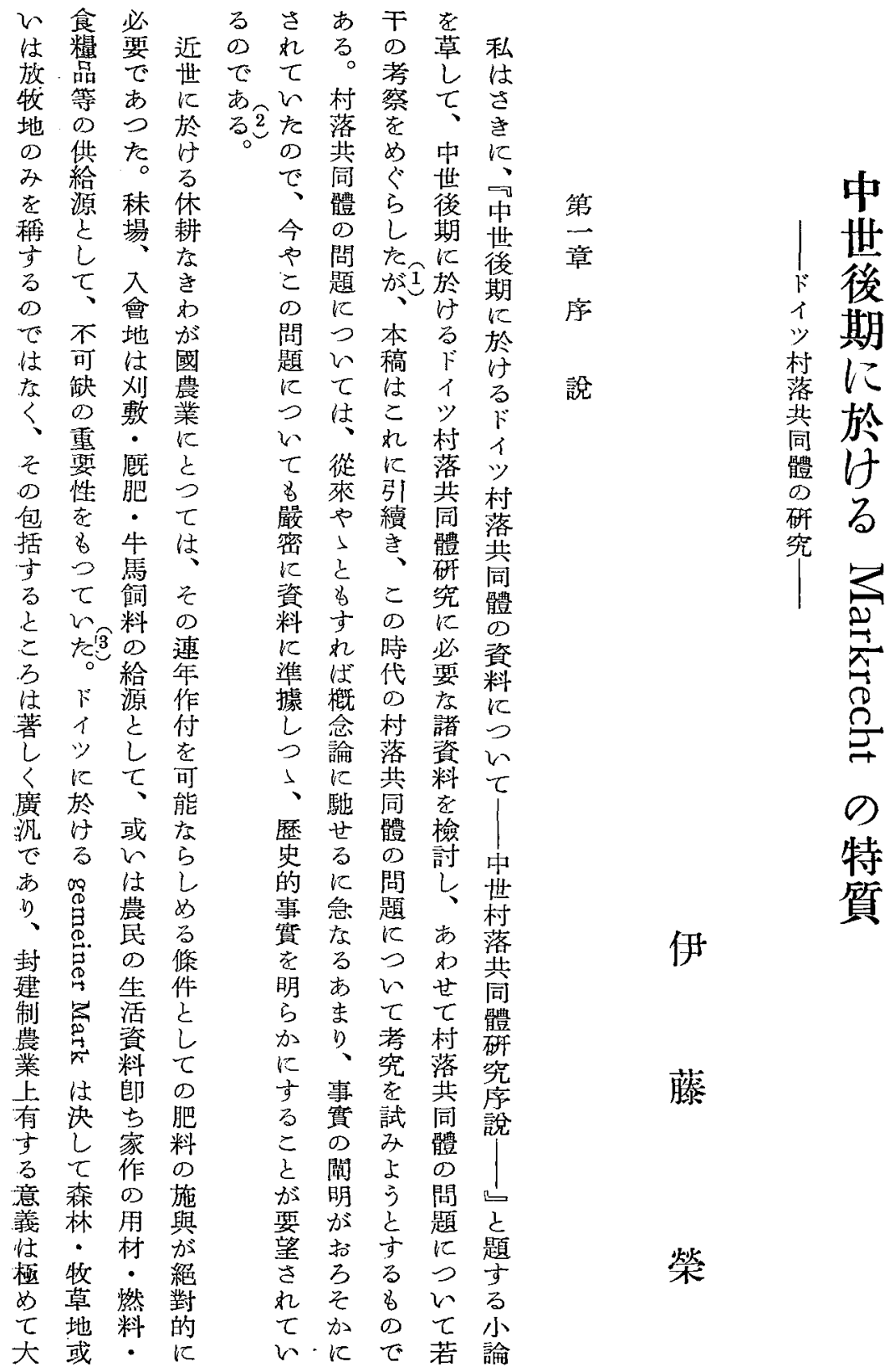


中世後期に於ける Markrecht の特質

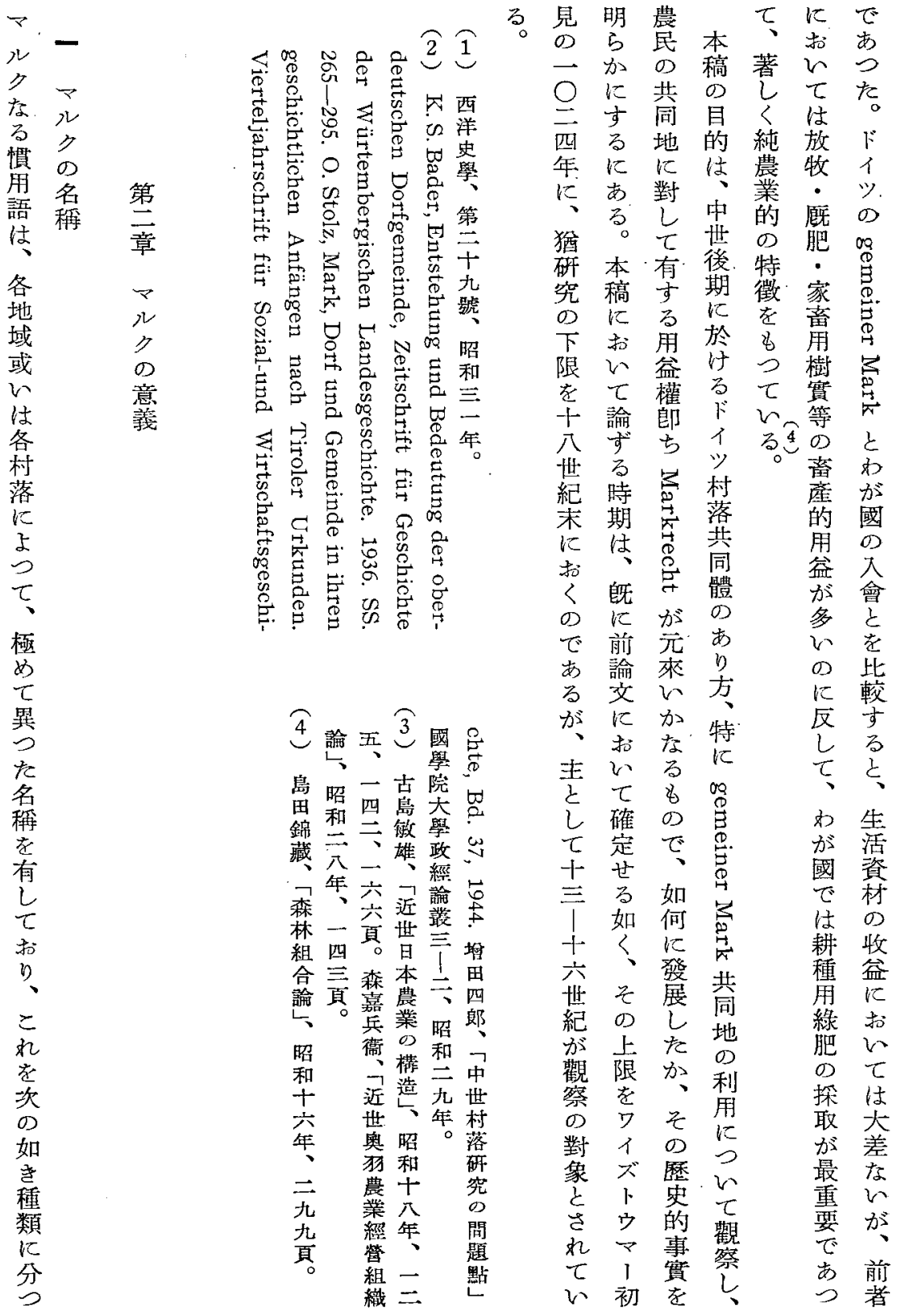




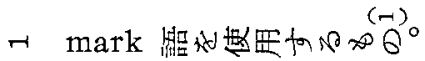

(3) mark; marchia; marika; marich; gemarke; gemarkde; gemarte ; gemerk; gemeine mark; gemein merk; gemein gemerke.

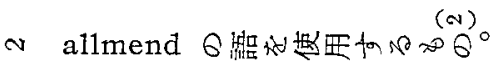

D almend ; allmend ; almende ; almand ; almen ; allemen ; almin ; alman ; almat ; allmad ; almuot ; almud ; almunde; almeinde ; almeind ; allmei ; almai ; allemit ; allemenach; allemeinda ; allemeina ; allgemeine almeindia; alme; Dorf alme; allmy; almendu.

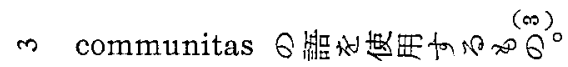

communitas; commune; marchia communis; campi communis.

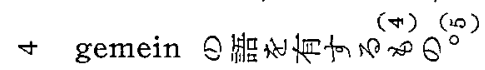

gemein; gemaina; gemene ; gemeine ; dorfgemein; gemeine felder ; gemeine güter; gemeine gründe ; alle gemein Veld.

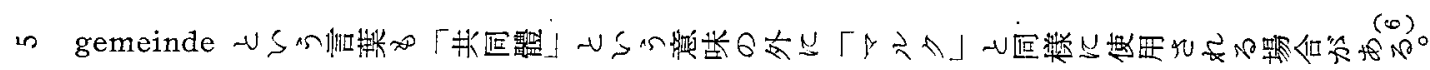

gemeinde; dorfgemeinde; gemeinheit; gemaind; gemeinde gründe.

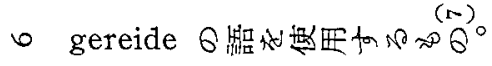

B gereide; gemein geredt; geraide; haingeraide; heinried; heimgereide; heimgerait.

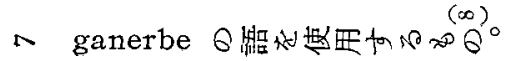


中世後期に㤎ける Markrecht の特犋

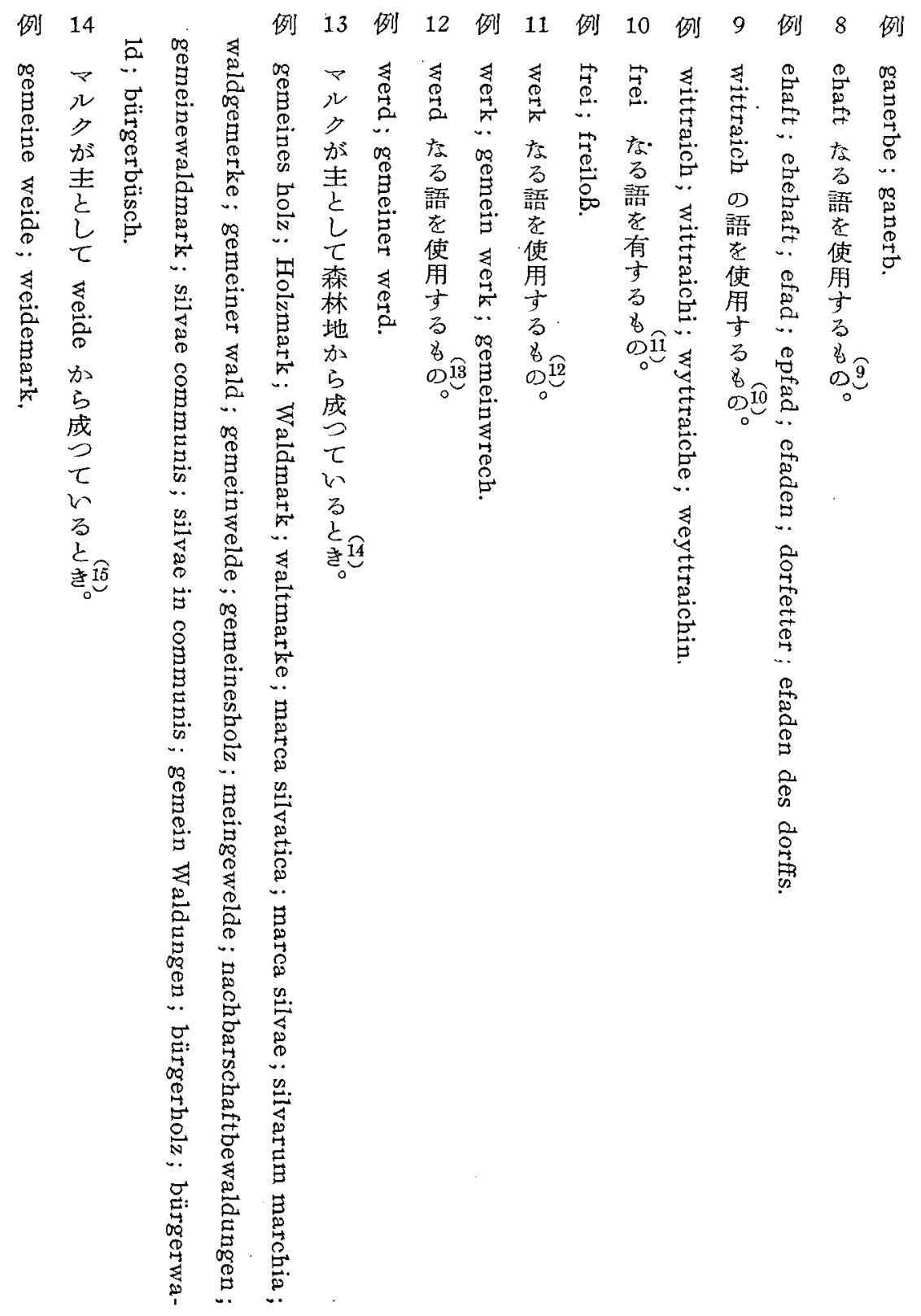




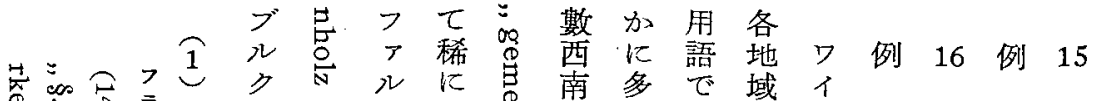

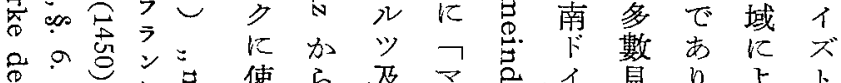
舟

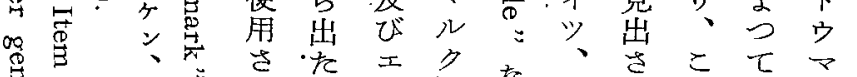

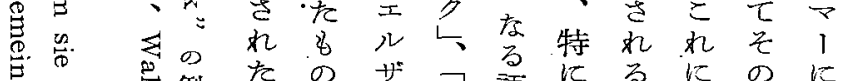

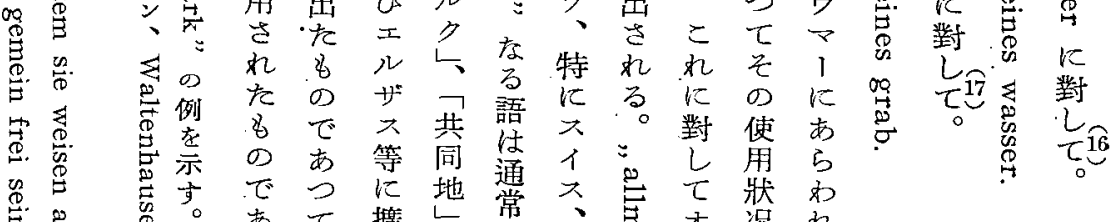
点 尽。市 导导 の

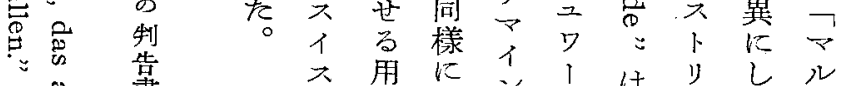

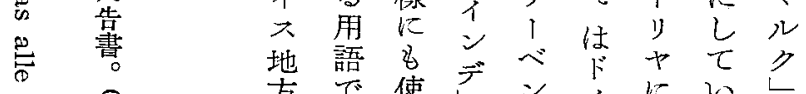

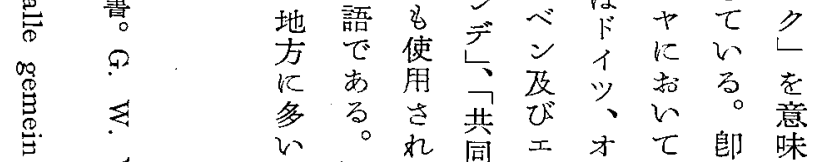

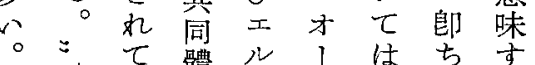

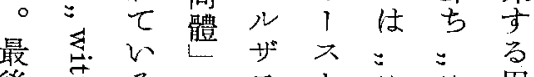

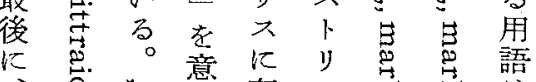

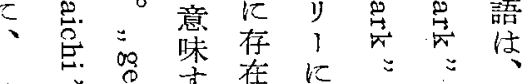

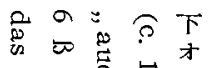

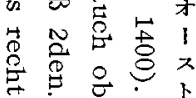
政

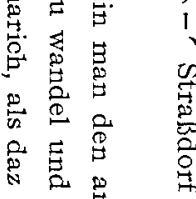
ㄴ. 节空莺物 总

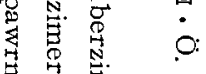

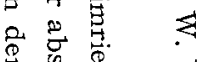
窟

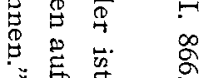

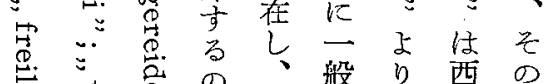

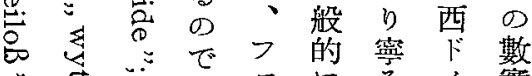
は怘

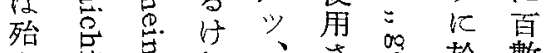
九怘要れ、要於數 $\xi$ 等 $\begin{gathered}0 \\ 0\end{gathered}$ シ ワ語の゙フ は 等 アラは

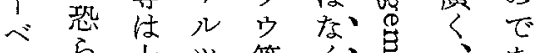

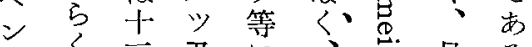

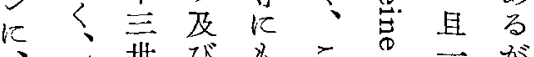

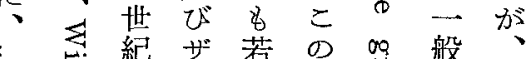

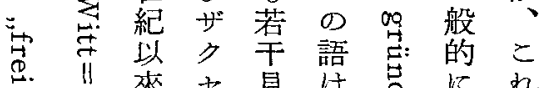

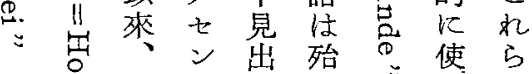

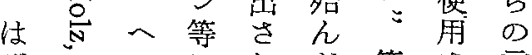
ザサッにれど等さ訔

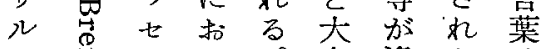
吕ンい。多遥た杜

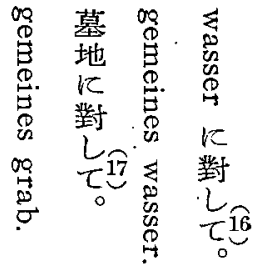




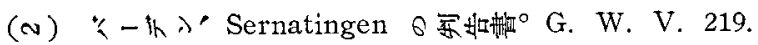
(1443).

„§. 21. Wer der waer, der an dez dorfs alman stieszi oder dem dorf daz sin invienz oder ruti oene ainen undergang, der ist verfallen $1 \mathrm{Pd}$. den.

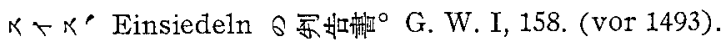
,34. Es ist ouch recht, wellicher eyn gütt zehenn jar vund IX loübrysynen vningefangen lygenn lat, dat dann denn nach eyn almeynde sy unerfordertt vnnd ansprechig."

(m) in $r \lambda$ Burtscheid 6 军如制 ${ }^{\circ}$ G. W. IV. 798. (1226).

„§. 8. Abatissa et conuentus in proprüs bonis qualia volunt possunt facere edificia ad suos et utilitates, sed in communitate nichil edificare debent nisi de consentu communi, advocati videlicet et kominum

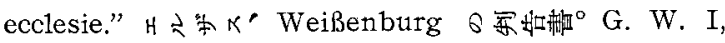
765. (1275)

„.....communes et almeinde vulgari vocabulo, ita quod abbas sit super his magister et dominus....."

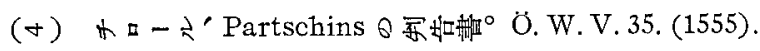
„und welcher kein wiesen oder acker betuend, sondern allein herbrig bestandsweiss innhät, der soll kein viechauf der gemein zu waiden haben, welcher ein haus bestuend und ein inngehansen einnehme, so soll er ihn selbs behilzen."

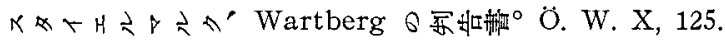
(1677).

„Hans Zehner Liechteneggerichter...... ist auch sein gross bitt mit der ganzen nachparschaft erlaubnus zuegelassen worden, ain kalbiz in die gmain zu dreiben, dafir verspricht er der gemain zu nuzen jär1ichen 15. kr. zu geben, doch sollches zu keiner gerechtigkeit sonder, so langs der nachbarschaft gefelig verbleiben."

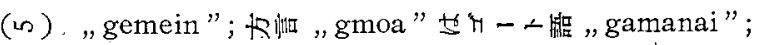

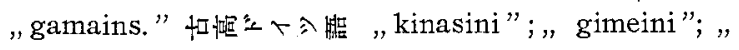

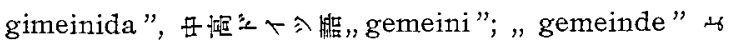
$\Rightarrow$ 王 $火^{\circ}$ Grimm, Dt. WB., Bd. IV. /1/2. Sp. 3170-3220.

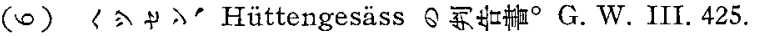
(1426).

"da wart gewiset, eyns tzu dem tage mochte er gebieten tzu machen und tzu bussen, was da an der gemeynde des dorff's buwefellig ader tzu brechen were, es were tzune, graben oder was die gemeinde antreffe, das mann das machte,....."

(N) $\mathbb{A} \leftarrow \lambda$ Gleiszweiler 6 采如艇, G. W. V. 572. (1568).

„§. 1. Das vieh zu Gl. wurd den nehsten vom dorf uf die gereiden getrieben, so weit man dieselben er- 
reichen kan, gleich andern gereidengenossen." $\wedge$ A $\lambda \lambda$ Kirchzell 6 军如㘉 ${ }^{\circ}$ G. W. VI. 7. (1395) „\$. 13. Item, wann ez were, das man buwet uf der heinried oder uf der gemeinde, ez were zu Zelle oder in den obg. dorfen, da von sol eim apte und sim clo. ster ein vasz-nachthun werden mit sin rechten, wann die eigenschaft des closters ist."

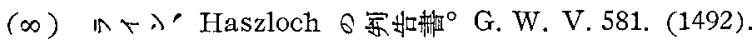
„§. 14. Me hat dic gemeind recht die und weiszet uf den aid,dasz Heilsprucker mühl kein wasser auszführen soll,dan uf den ganerben."

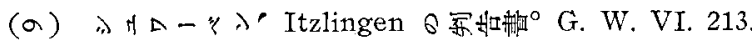
(1625).

"Copia des dorfs zue Itzlingen ehehaften."

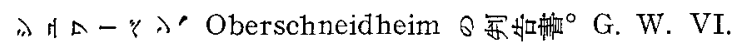
210. (1568).

"Copia ernewerter Schnaitheimer ehehaft anno 1568."

(ㅇ) "

"allh ferr die wyttraichi vnnd gewaltsammy gäth ......"

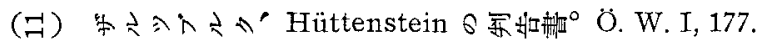
(18. Jh.).

" daß er mit drei messerschnitten sambt dem ast abgenommen werden kann, dem vorigen aigenthumber alleinig, sonst widrigens aber denen mit einander, so er aber in einen baumb auf der frei oder gmain sich gelegen; dem findun alleine zuestendig sein so11e."

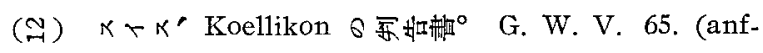
gan des 15. Jh.).

„§. 26. Es soll ein probst haben teil nemen, waz nuzzes und genieszes von den hochwälden und von đen hölzern und wälden, die gemeinewerk sint und heiszent, gevallet,......"

(곡) G. W. I, 735. Drusenheim.

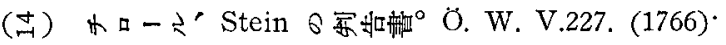

"Zumahlen auf ratification der hohen herrschaft etc. die ainsmahlen außgethailte gemainsbewaldung von wohlgemelten hohen wesen....."

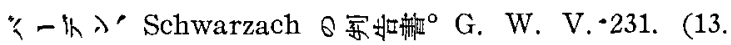
Jh.).

„§. 10......simili modo in silvis communibus rusticorum de Selingen et Húgelsheim per duos dies in septimana, quam ditı duratur."

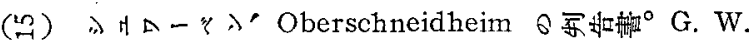
VI. 210. (1568).

„§. 2. Zum andern, dieweil sich biszhero etlich in unser gemaind gehalten haben mit besonderem hueten mit ihrem viech, wie das genannt ist, und also etliche gemeine waid vor uns andern abgefretzt und 
allein die böste herab genossen, das dann mit billig ist, solches verbieten wir einem ieden bei vier böhmischen."

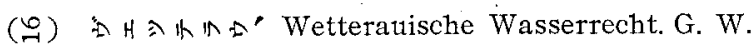
III. 467. (1611).

„Wie dann auch hauptmann zu jeder zeit, seiner ge- legenheit nach auf beyden gemeinen wassern, zu Dorheimb und Fauerbach, darinnen den nachbarn $z \mathfrak{u}$ fischen vergönnet wird, von alters herkommen $\mathrm{zu}$ fischen oder fischen zu lassen macht hat."

() G. W. I, 800. (1491).

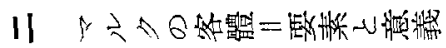

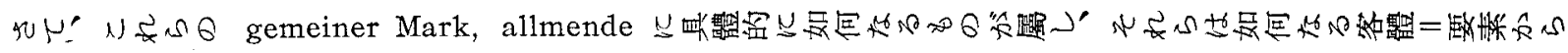

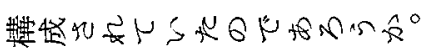

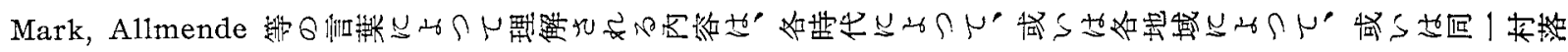

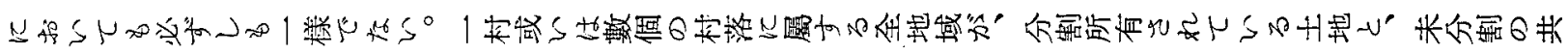

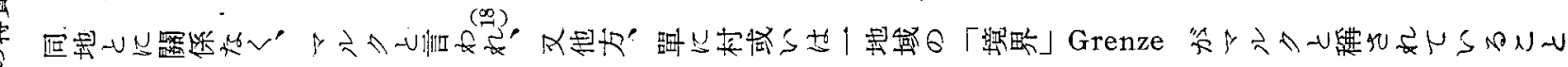

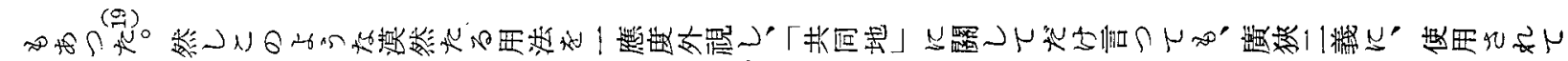

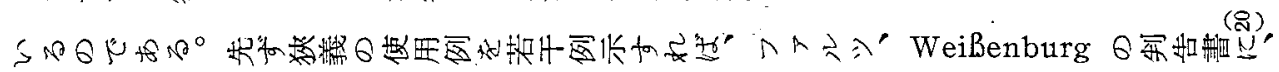

„omnes alie sylve-_ sint communes et almeinde vulgari vocabulo."

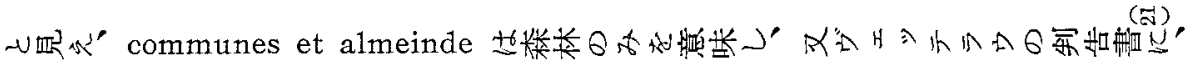

„§. 15. Auch ist me fon den cingrafen uzgedragen, daz iecliches dorfes gemeine hirte uf daz andir faren mag, wa iz ane schaden mag gedtın, nach alle dem rechte, alse der gemeine hirte fon Frankenford zu driben hat gewalt, mit solichem underscheide, daz man in der dorfe holzmarke mit keinem fehe 
đriben sal."

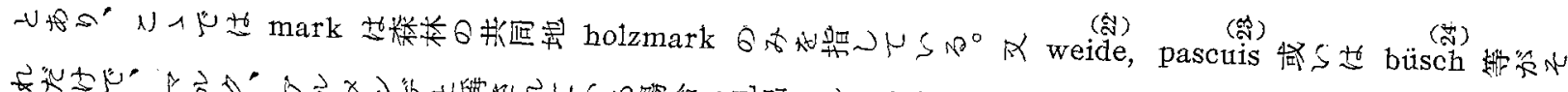

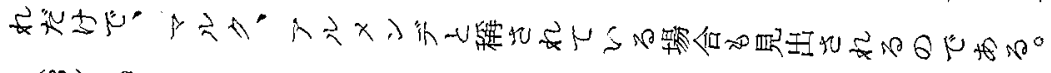

$\left(\begin{array}{c}\infty \\ -1\end{array}\right)$ G. v. Maurer, Geschichte der Markenverfassung in Deutschland, 1856. S. 27.

(ब) O.. W. I, 34, 55. III, 115, 310. VI, 49, 87 etc.

(尺ి) G. W. I; 765. (1275).

(- $)$ G. W. III, 485. (1309. oct. 29.).

(ָํ) G. W. V. 714. VI. 286.

(ふ) G.W. I. 765. (1275).

(冠) G. W. V. 231. (13. Jh.).

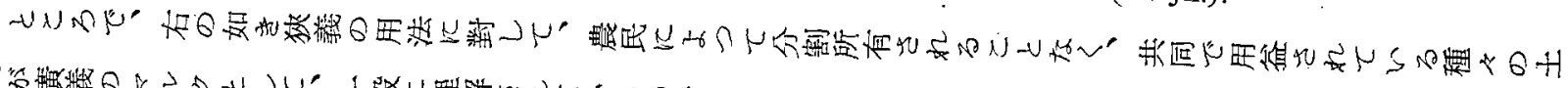

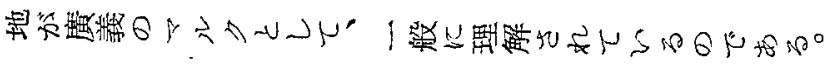

H

"Wäre es sache, dass die gemeine landschaft des Ringawes mit einande: zu sprechen hätten von sachen das land berühren, so mag die landschaften willkühren, bey eynander zu kommen auf der Lützelnawe bey einer pön, und ein hagelsprach hallen; desgleichen mag jeder flecken und dorf zusammenkommen, und ihre marke berichten, als zum wald und weid, holz und trifft, weg und steg und anders zu thun, als dick des noth ist lande und in ihren marken."

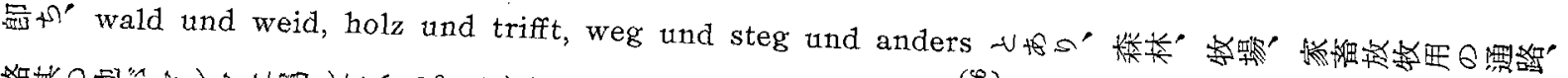

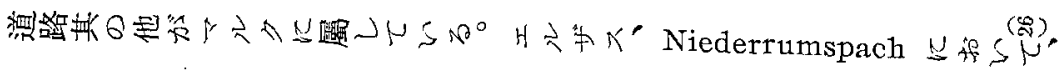

"daB all allmenden, sy sygent in holz, veld, acker, matten, und was dazugehört."

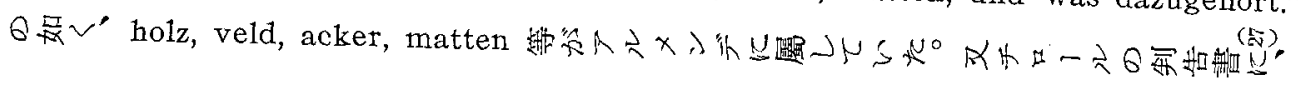


„S Siebentens soll ein ieder dorf und waltmaister achtung geben auf alle weg, steig und steg, wasser und wasserwehr, und was sonsten an andern dingen zur nachparschaft nutzen gedeien mag,....."

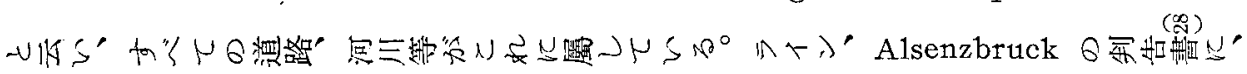

„, so sollen die gemeind zu Alsenzbruck forder denselben bronnen sonder unser herrn v. O. schaden in ihrem eigenen costen baw vnd wesen ewiglich halten......

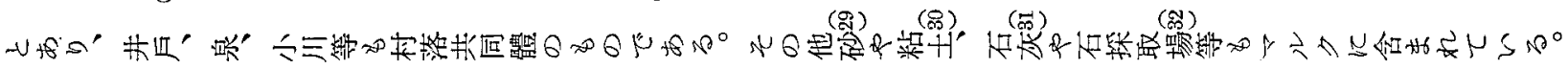

(ลู) G. W. I. 539. (14. Jh.).

(㣽). G. W. I, 662. \$. 12. (1457).

(ล) O. W. V. 414. (1721).

(c心) G. W. I, 792. (1507).
(尺) O. W. VIII, 62, 969, 656 etc.

() G. W. I, 129. (1536). Töß.

(m) . Ö. W. II, 29, 38. IV,314, 380. V. 94, 170, 192 etc.

(iv) Ö. W. VII, 815,993 etc.

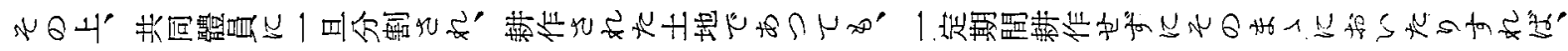

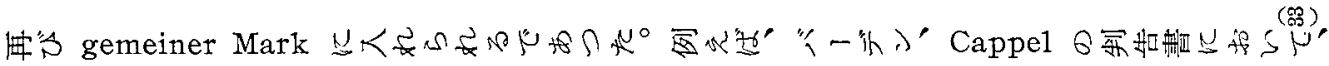

"was ouch in zehen jahren nit gedungt ist, bosch vnd berg, dz sol sin ein gemeine weid."

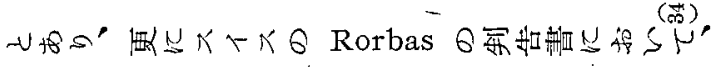

"der soll da vermachen, wo er das nit thete, so soll er den acker lassen ligen zu der allment."

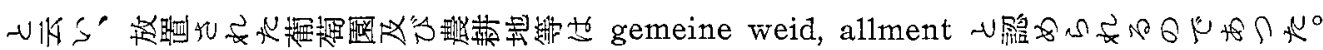

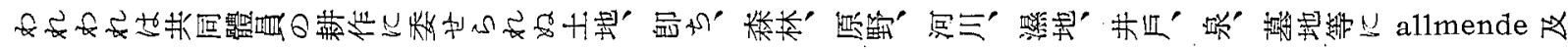

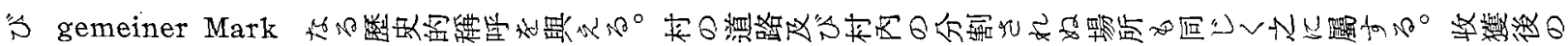

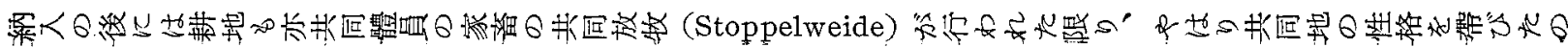




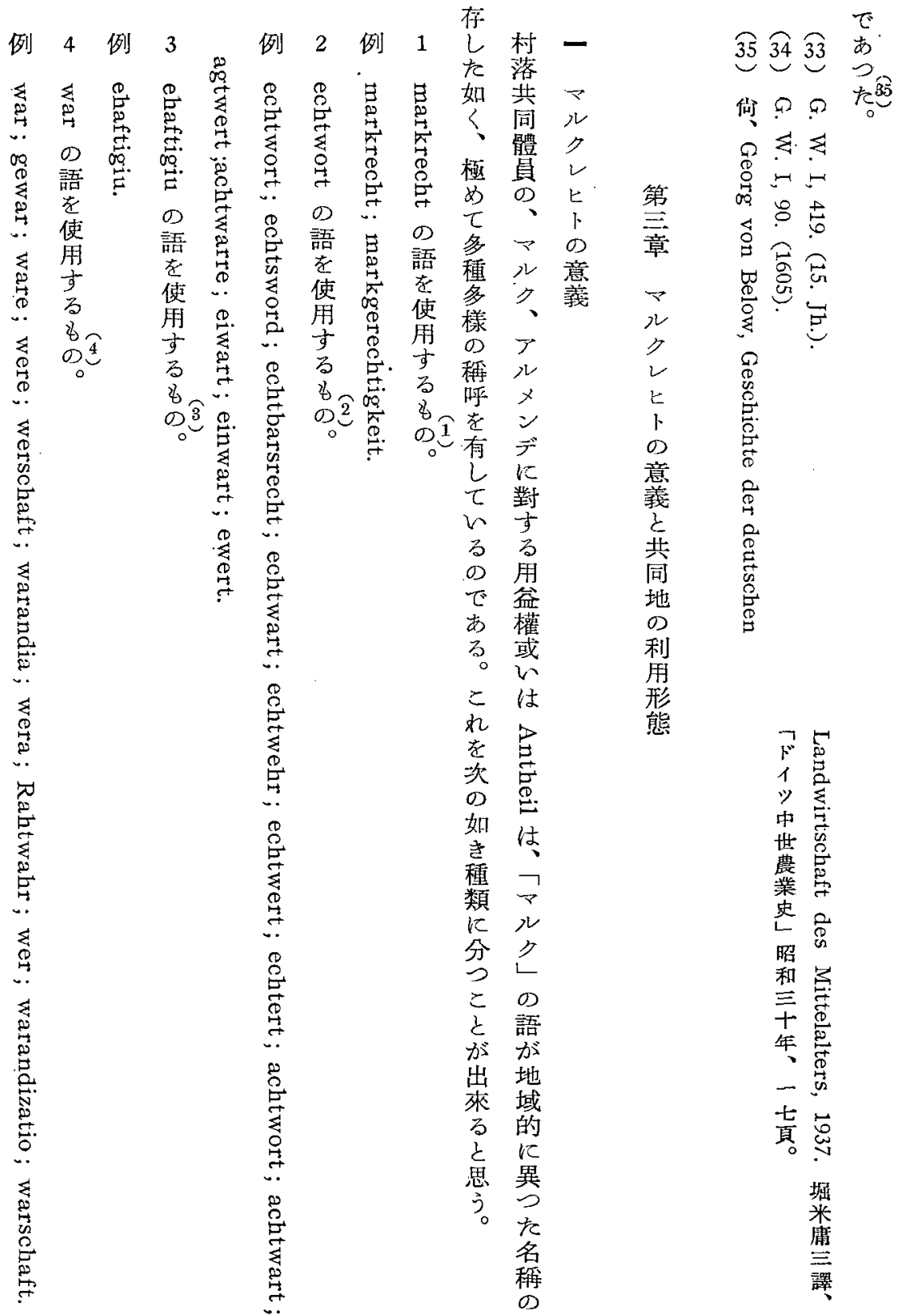




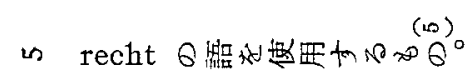

Fecht; gerechtigkeit; mastrecht; gewalt.

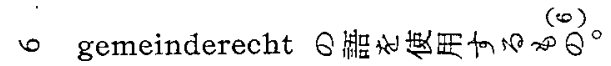

gemeinderecht; dorfrecht; nachbarrecht; dorfnachbarrecht; bürgerrecht.

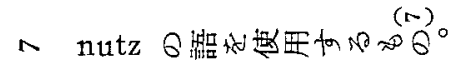

nutz; nutzung; nutz und brauchen; gemeinen nutz; nutz und were; gemeindenutzen; gemeinnutzen.

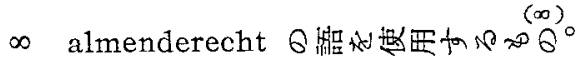

$\$$ almenderecht; allmenderecht.

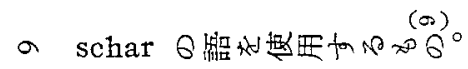

Schar; schara; scara.

을

\$ alprecht; rinderrecht; hüttengerechtigkeit; kuhrecht; kuhessen; gras weide.

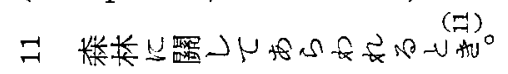

holzrecht; waldrecht; waldnutzung; beholzigungsrecht; jus silvae.

ㄱ. 吅

mark; allmende; gemein.

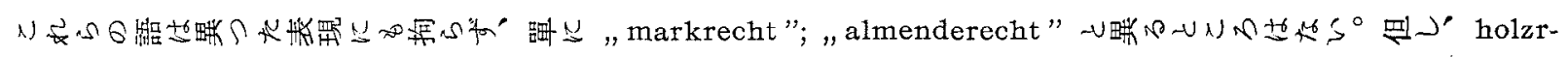

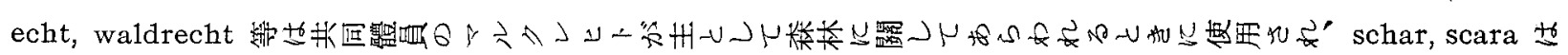




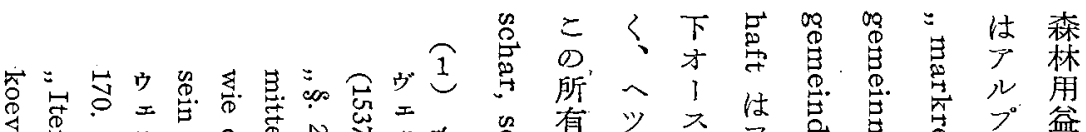

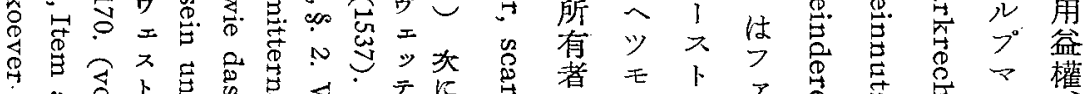

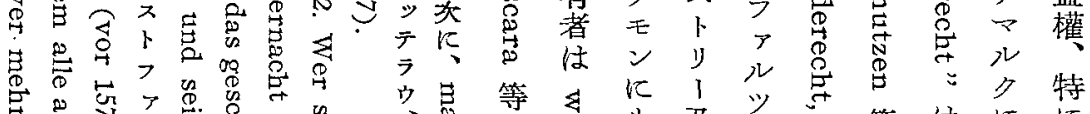

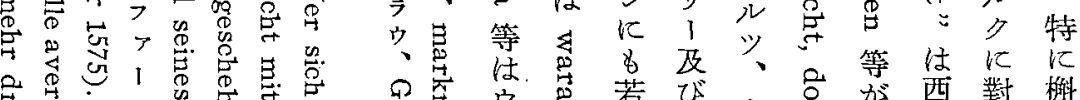
虽怘

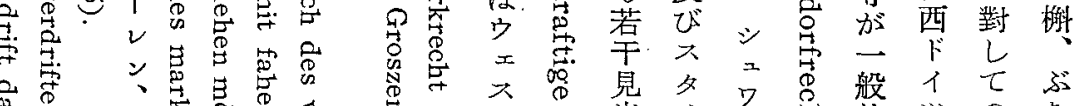

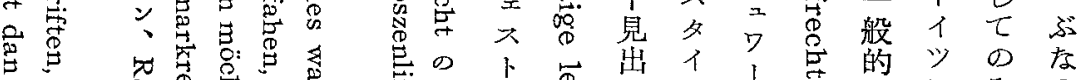
E $\begin{aligned} & 0 \\ & 0\end{aligned}$

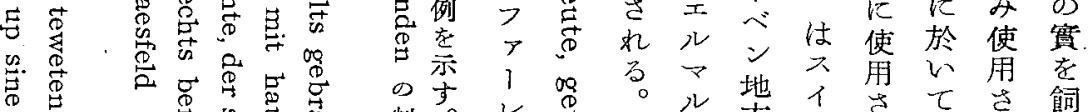

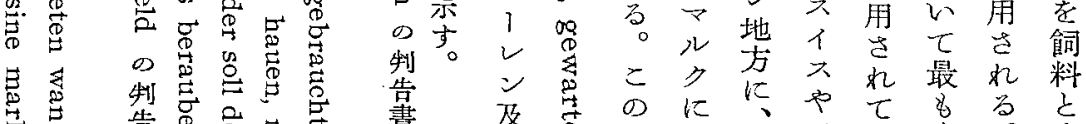

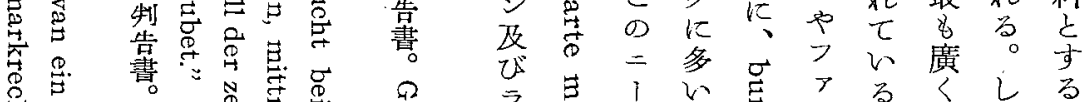
含

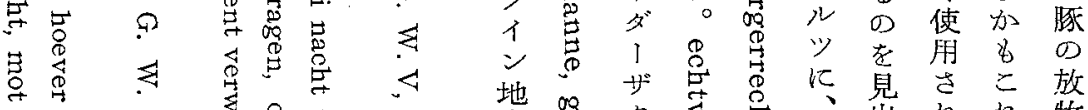

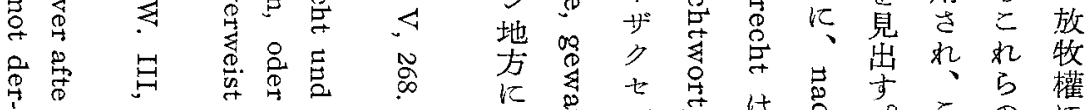
㝵穴 指 $\stackrel{9}{\oplus}$ 户 3 $Q$ 市 «

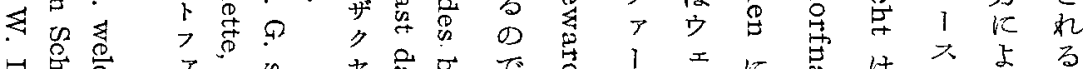

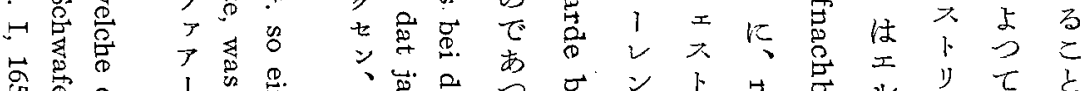

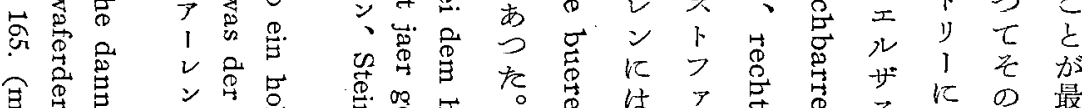

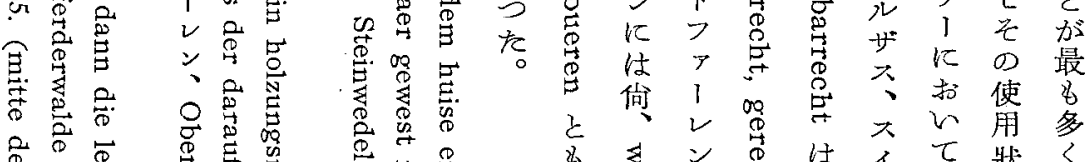

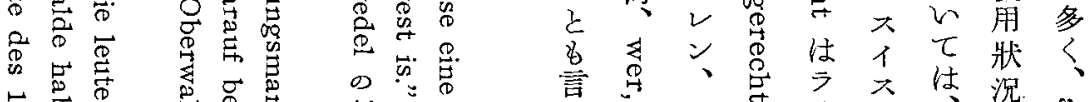

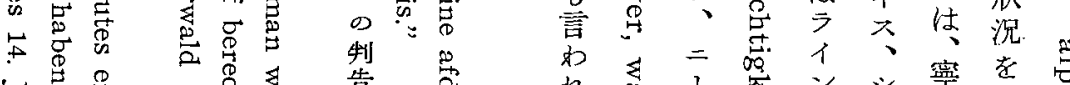

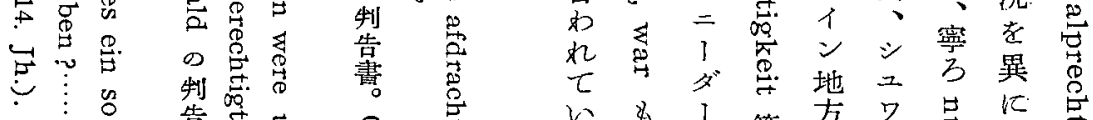

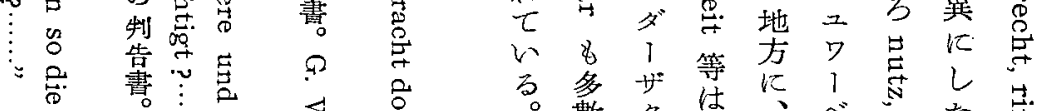

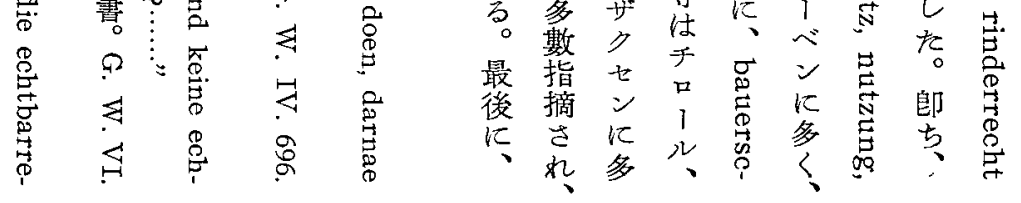




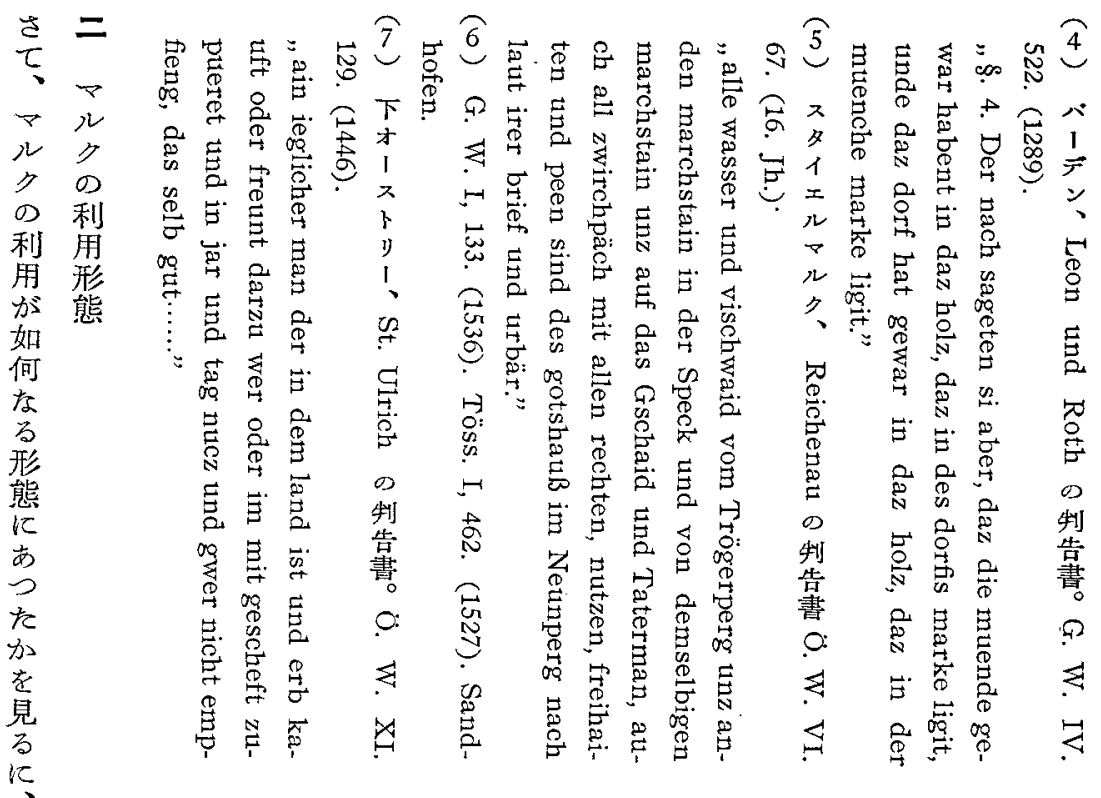

第

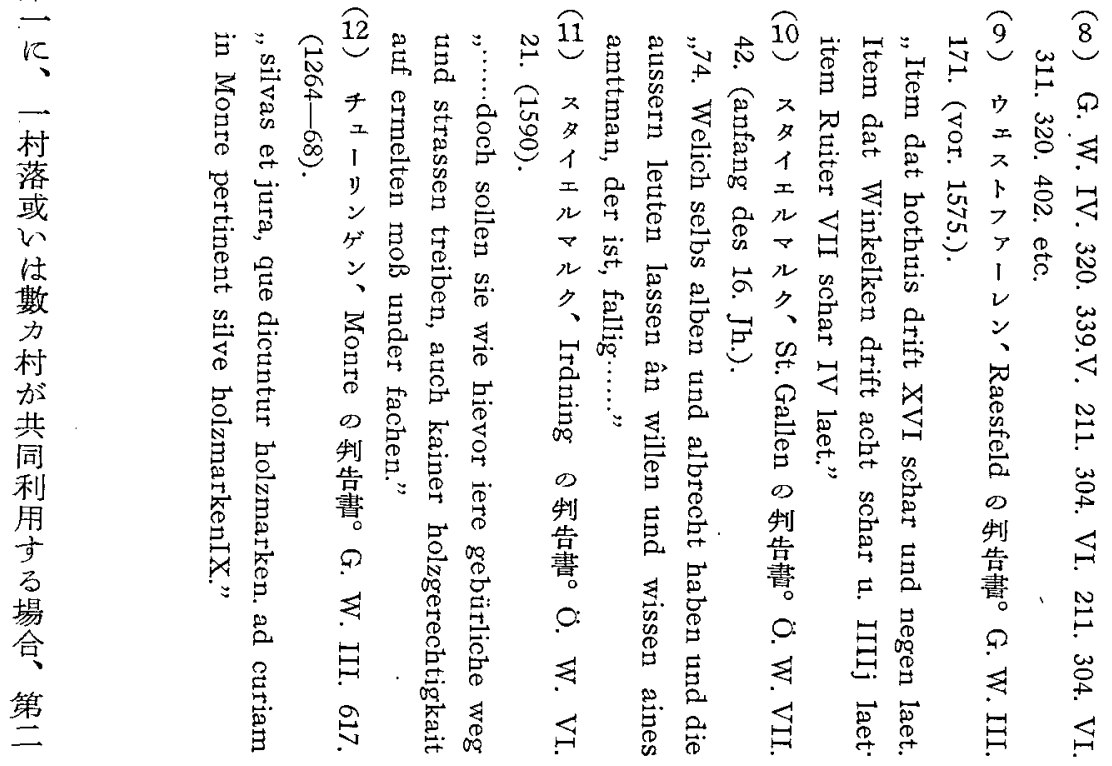




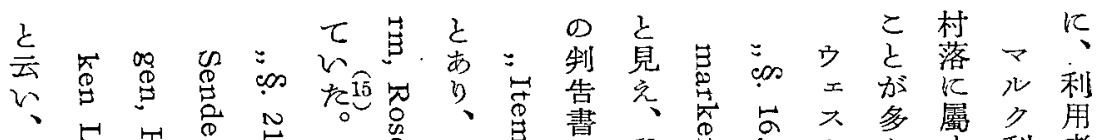

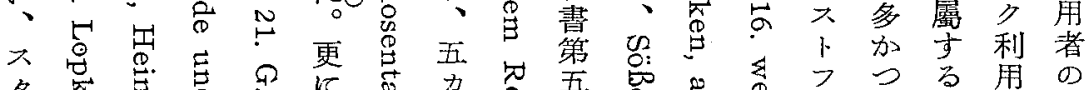

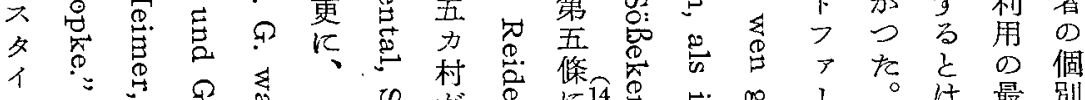

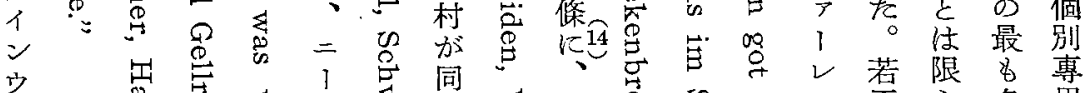
× 㕝

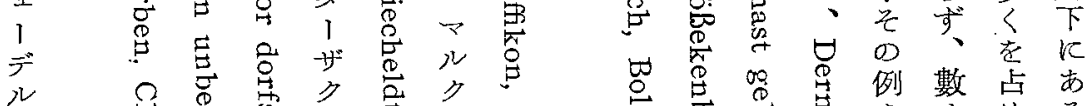

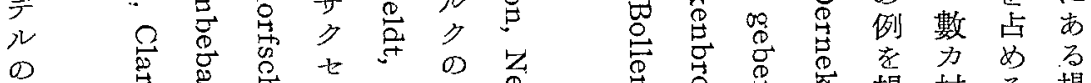

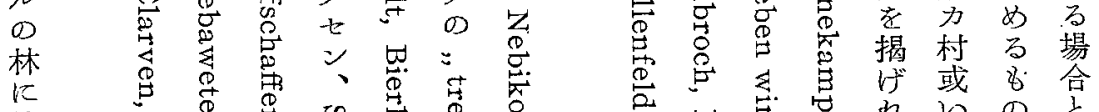

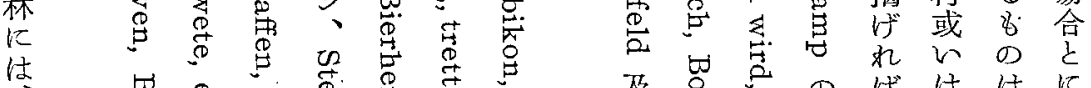

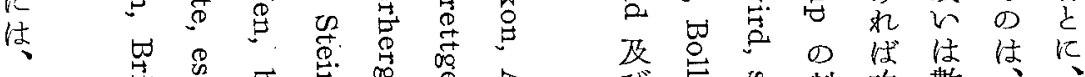

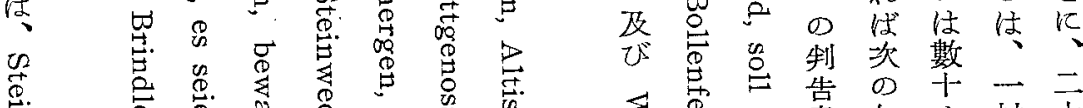

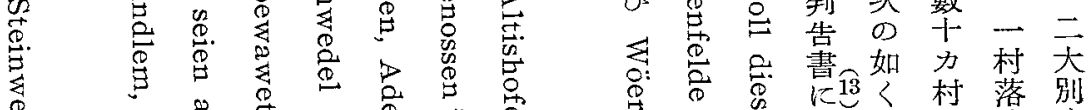

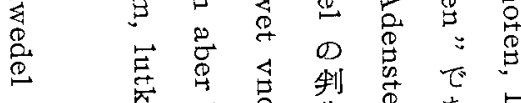

老

初 点

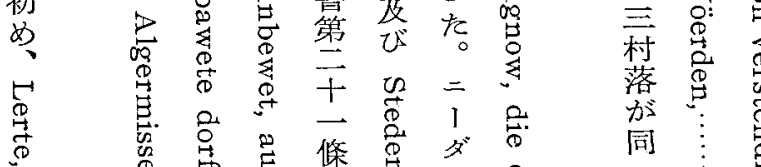

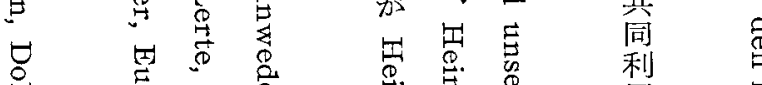

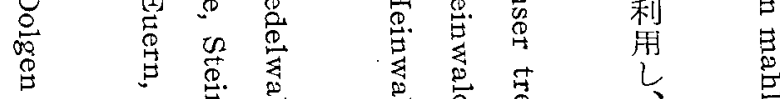

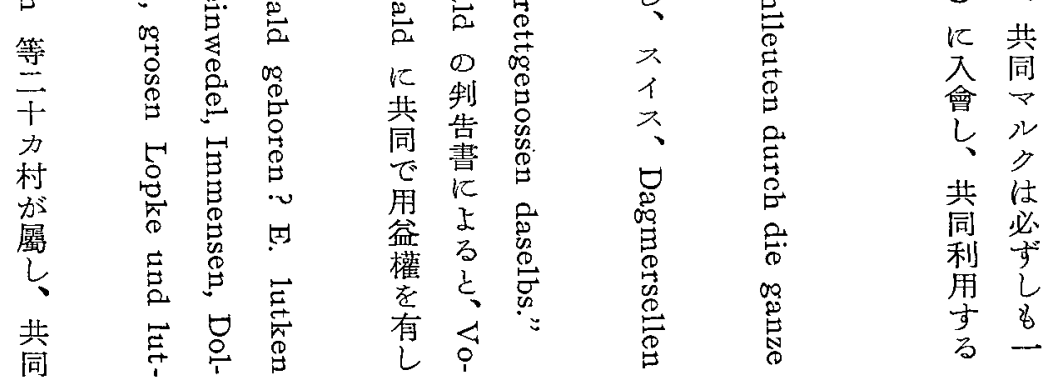


中世後期に於けま Markrecht の特質

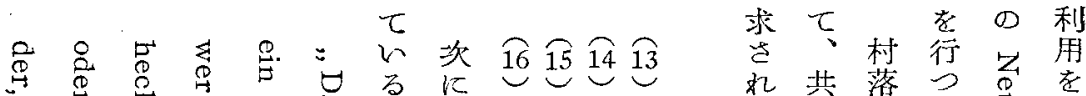

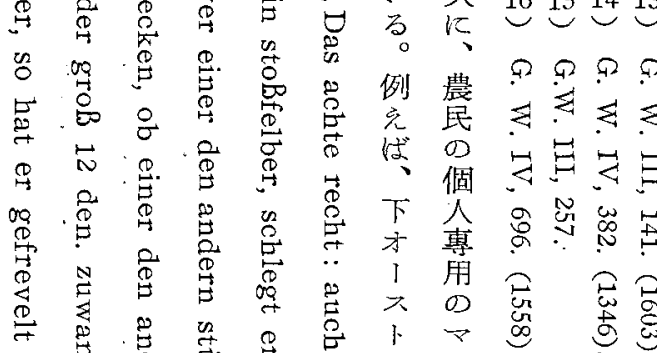

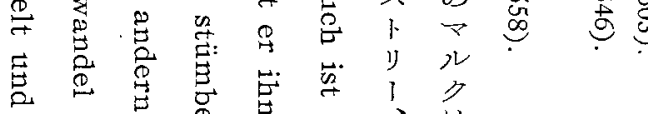

希

苛哇

品・高

常

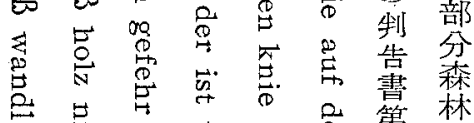

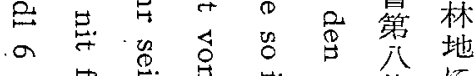

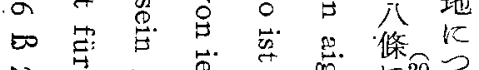

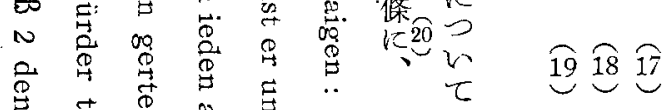

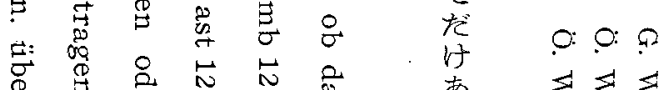

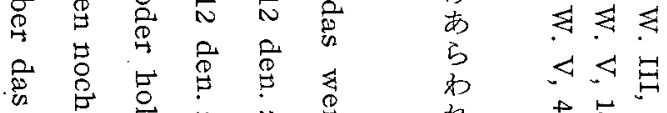

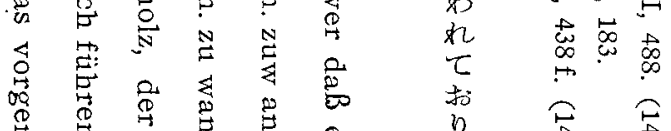

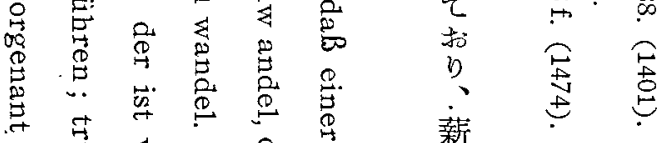

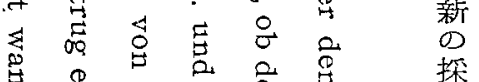

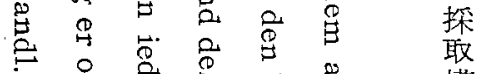

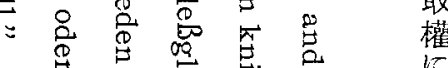

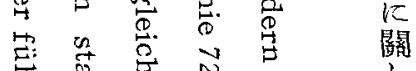

旁惫兽

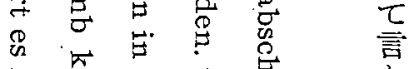

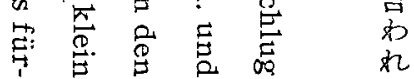

共落了杂青

盾共て 䓌行

で地同い體た 点方

あ共員のにい

つ同はで於る

を利、あいこ

用森つ西

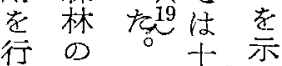

利 三18

用和

利に同 0

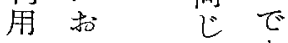

の

方手方。

法或口嵒

招以少

以.は の

$\tau$ 牧宁

8 場 厹

期休胥少

に耕葛导

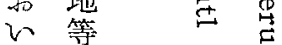

$\tau \sim \infty \stackrel{\overrightarrow{0}}{0}$

80 学离

人畒名

D 0 に

自放 牧 賣

なに仡

行括四 三

動 尔

は.七七 七

制

限 或 村 村

さ

れは唯共

、㲦入同

共草會 體

同作 ᄂ 註

活 等 共

動に同口

が招利 !

要 


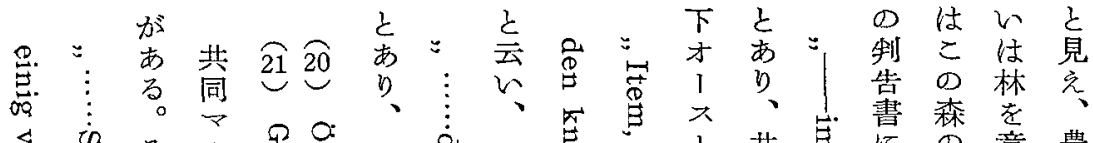
它 冓 吕 例

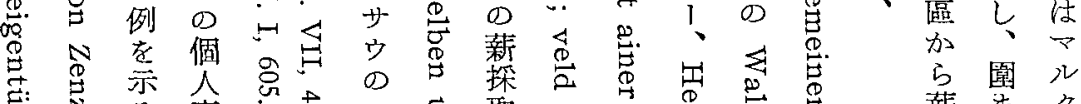
节品示人

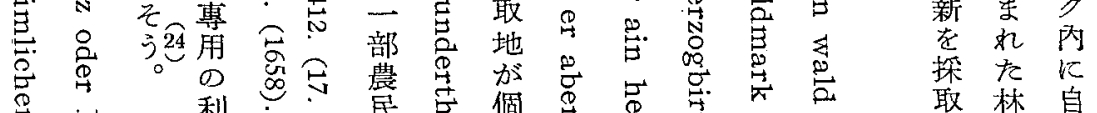

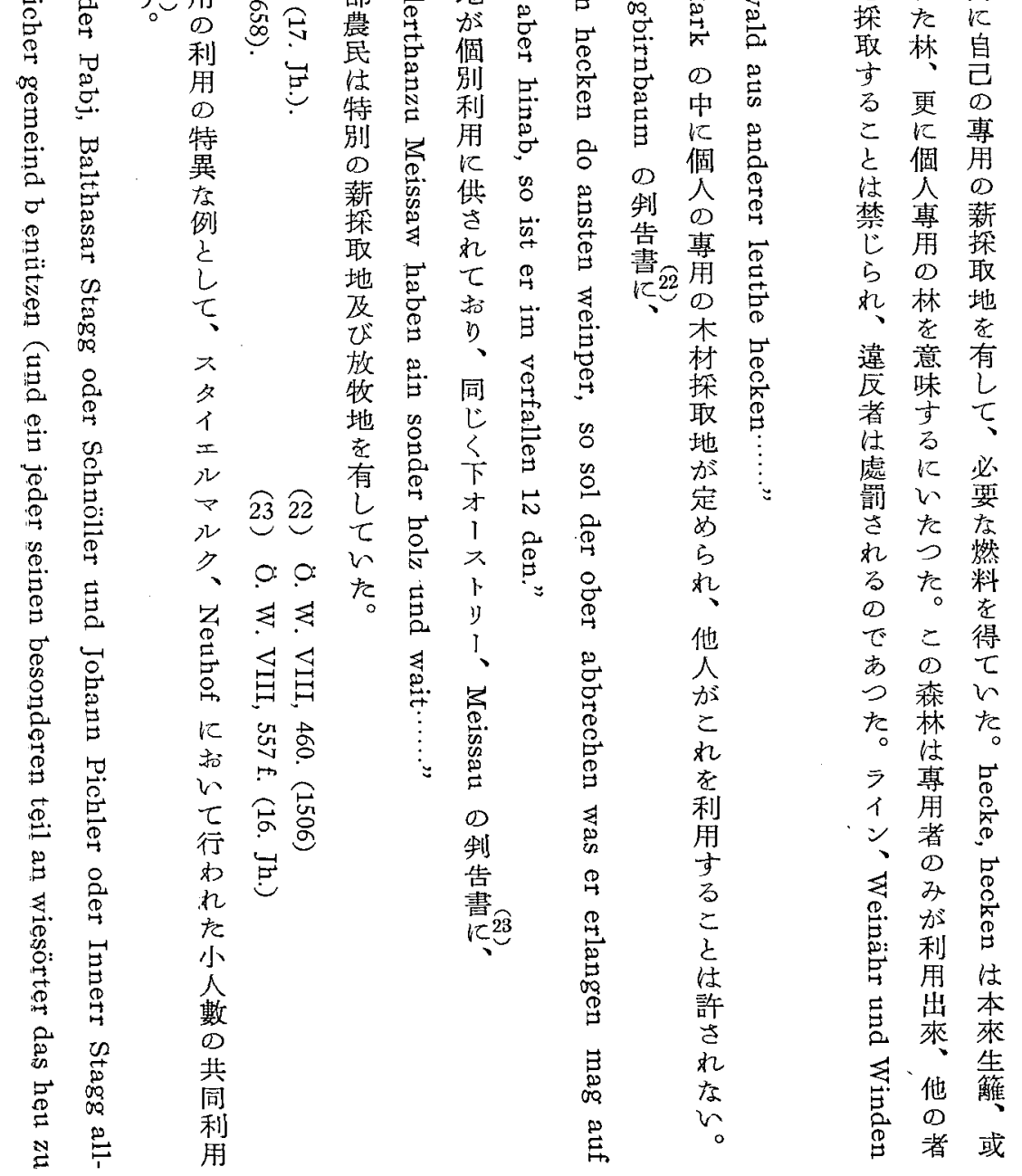


中世後期に於ける Markrecht の特質

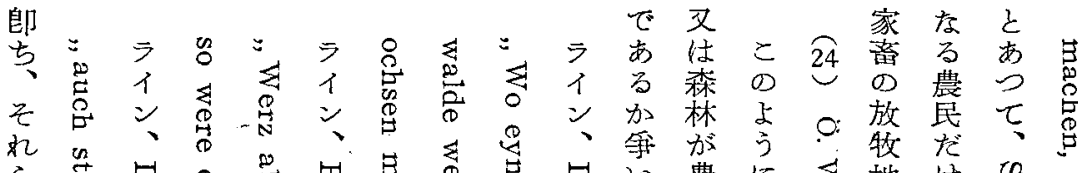

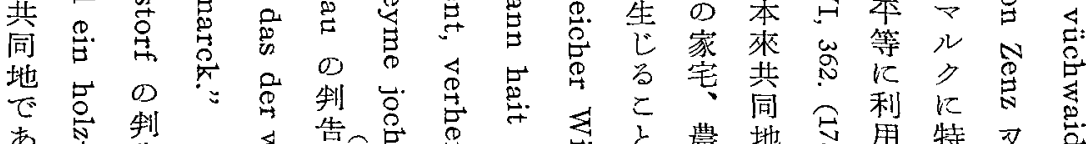

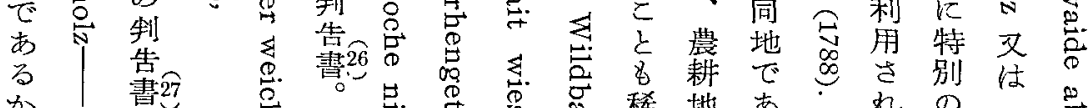

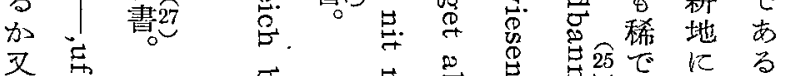

個

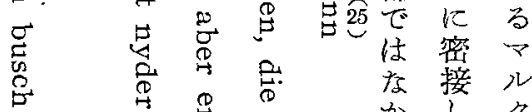

私里

有

に

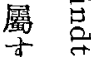

る 离

鳟合

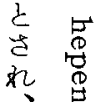

等

认氶

が

生葛

te

結

そ $\stackrel{0}{0}$

解 范

決

t

め)

k $P$

叢

林

の

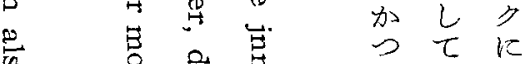

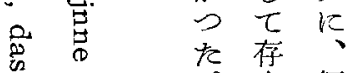

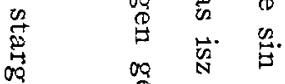

在 個

事次市人

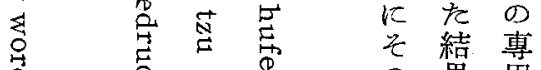

苗

$\stackrel{\vec{R}}{\stackrel{P}{8}}$

空

岑

$\stackrel{8}{\mathbb{0}}$

ஜ

○果 角

例利

をを用

\%

\% 劳

兽

示乃或

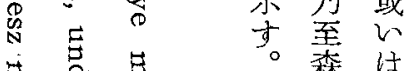

き节䒠。森は

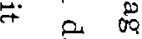

莫

林 そ

がの

個 用

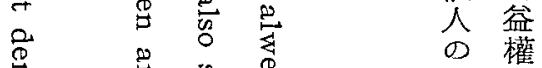

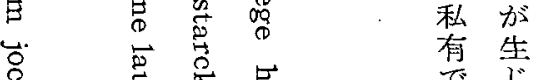

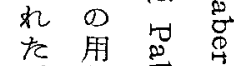

でじ

る 結

草 承泀

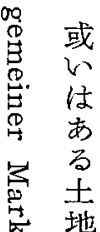

益 權 㟔

有

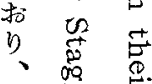

乙文宫

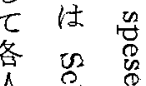

人. $\stackrel{0}{\stackrel{8}{*}}$

草

地 及 $\stackrel{8}{\stackrel{9}{\rightleftarrows}}$

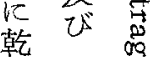

草鸟总

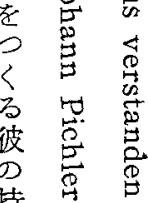

持

点爷恋

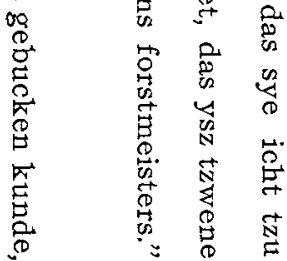

者出

有

\begin{tabular}{ll}
$L$ & 0 \\
另 & 0 \\
\hline & 09 \\
\hline 0
\end{tabular} 
乙争わ的

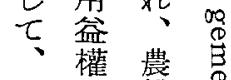

そを耕 尽.

の總地

農 稳 の品

耕 し 處吕第

地七分荝四

にフに 章

附，随:

隨 フ号邑

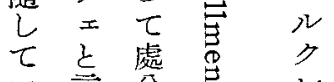

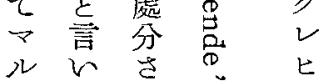

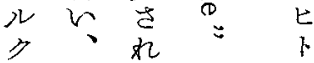

用 $\checkmark$ 万的

益儿場 對性

權名高格

8) 用 0 万

附益 あ 農

與 權 る 民

¿ $\lesssim こ \infty$

れみと權

七峁の利

單 $引 \infty$

万獨与重

事でに 要

貫處 \& 性

が分覛 枯

各さ

所饥知本

江得る 秝

見应元

出小主 $\infty$

己つ艺家

れた出屋

る の來 敷

のでる及

であ。び

あり家 農

る、屋、耕

從敷地

七 農 二

小耕 體

作 地 之

契及

約 びて

に文取
27 26 25 市

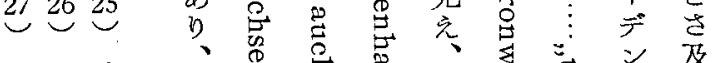

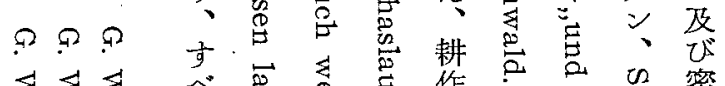

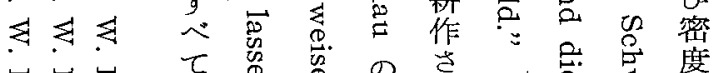
$\mapsto \mapsto 5$ 七

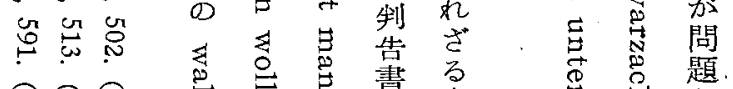

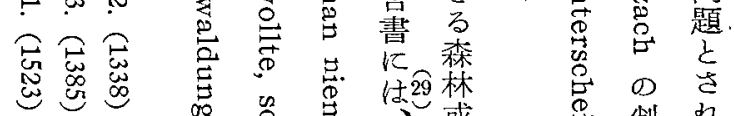
足. 制 れ 哇書 舊 长來

$\rightarrow 28$ 慣

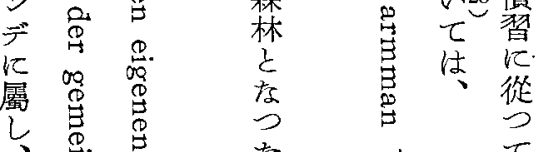

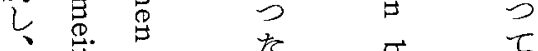

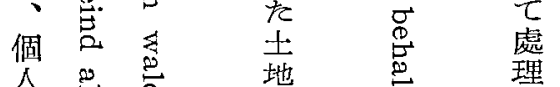

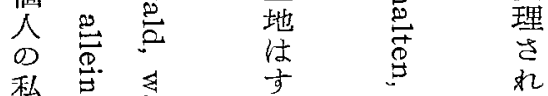

䏬离

2928 क

(1) 1 は 同

乡 認 官地

占占 $\quad$ 如

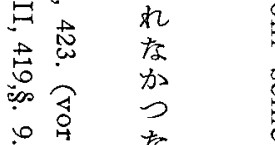

它苦

で

あ

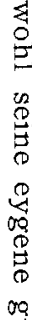

$\stackrel{\mathbb{P}}{\rightarrow}$

营

$\stackrel{4}{\stackrel{4}{4}}$
ヘ

共

屬

to

$\infty$

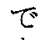

あ

つ

to

又

ヴ

工

$\%$

$\bar{\tau}$

э

り
『 る

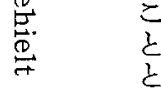

业

然

声.

孛 柱

r

方

屬

\& 霓

닌

$\div \quad \infty$

ᄅ

8 水

点 七

\& b 
中世後期に於ける Markrecht の特質

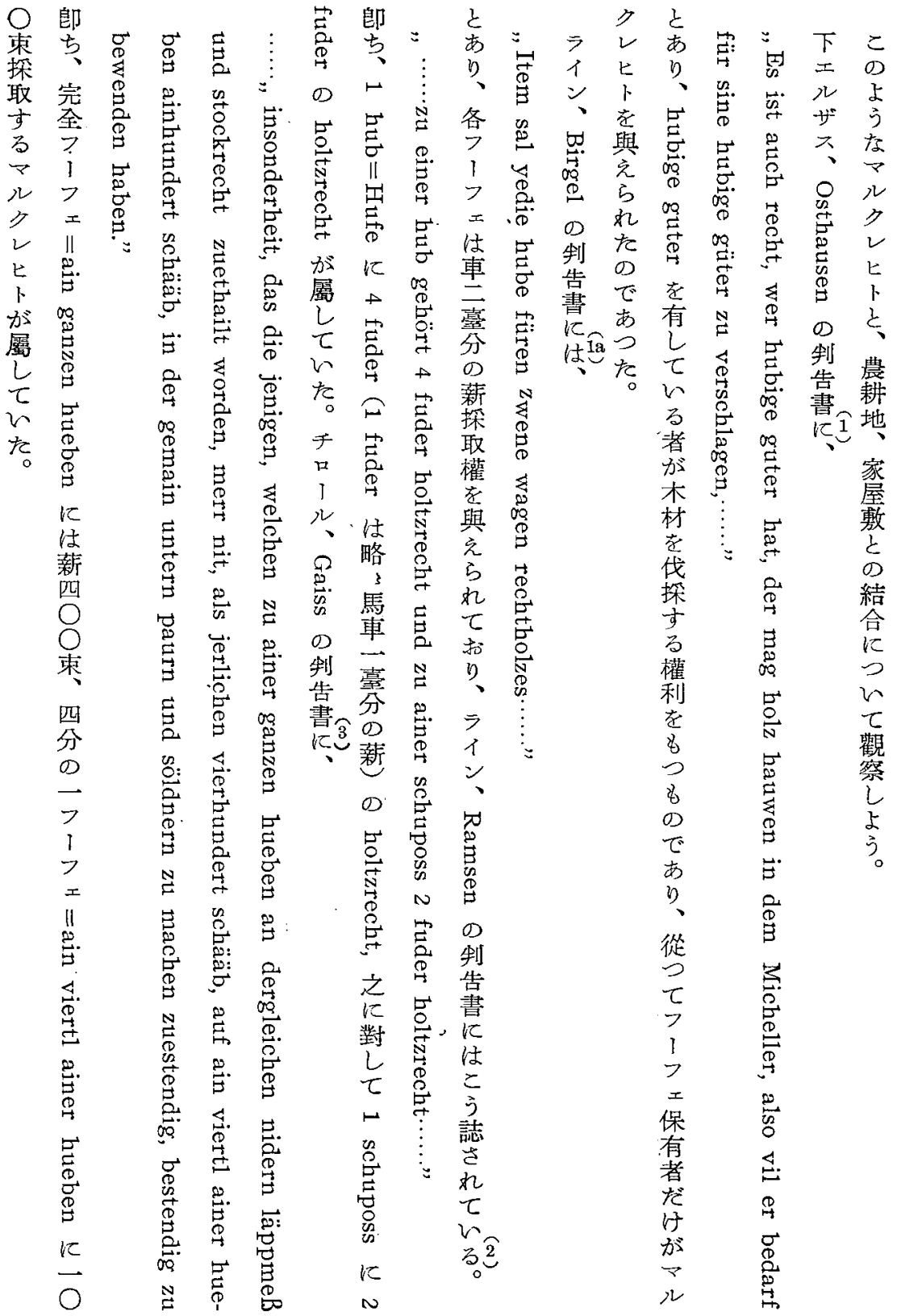




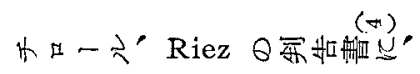

,Item auch melden si, das ain lechenman zu Rietz gewalt hat, zu slachen zwen fiöB, und ain selman ainen flos in allen wälden, die zu Rietzgehören, ân anzgenomen in dem Prunnach nit."

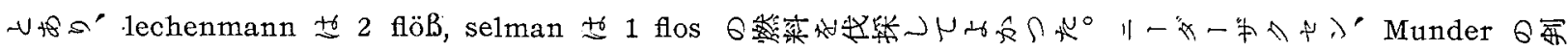

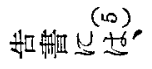

", wie viele erfflandes einer solle haben, der sich vor einen erben holt? Darauff żu rechte durch N. ingebracht, ein ferendell landes solle er haben, und ein ferendell landes sein vünff morgen."

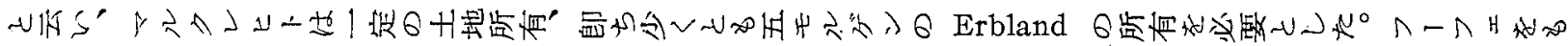

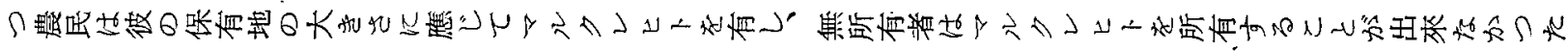
$\theta \log ^{\circ}$
(-) G. W. I, 710.
(») Oे. W. V, 510. (1668).
(豈) G. W. I, 516. (1419).
(ナ) Ö. W. III, 52. (1491).
(v) G. W.V, 615, (1390).
(is) G. W. III, 297.

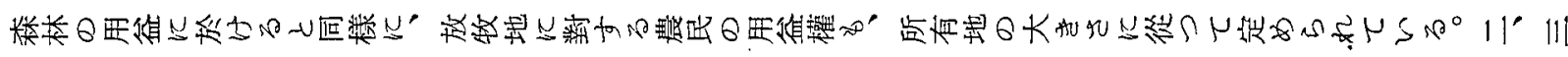

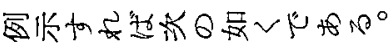

出

„....Auch hat ein jeglicher, der sein gut selbsten esset und bauet, und einen ganzen hof hat, recht zwölf schweine von seinem hof zu geben in die eckern, ob er sie selber drauf erzogen hätte… Ein halb 
中世後期に於ける Markrecht の特質

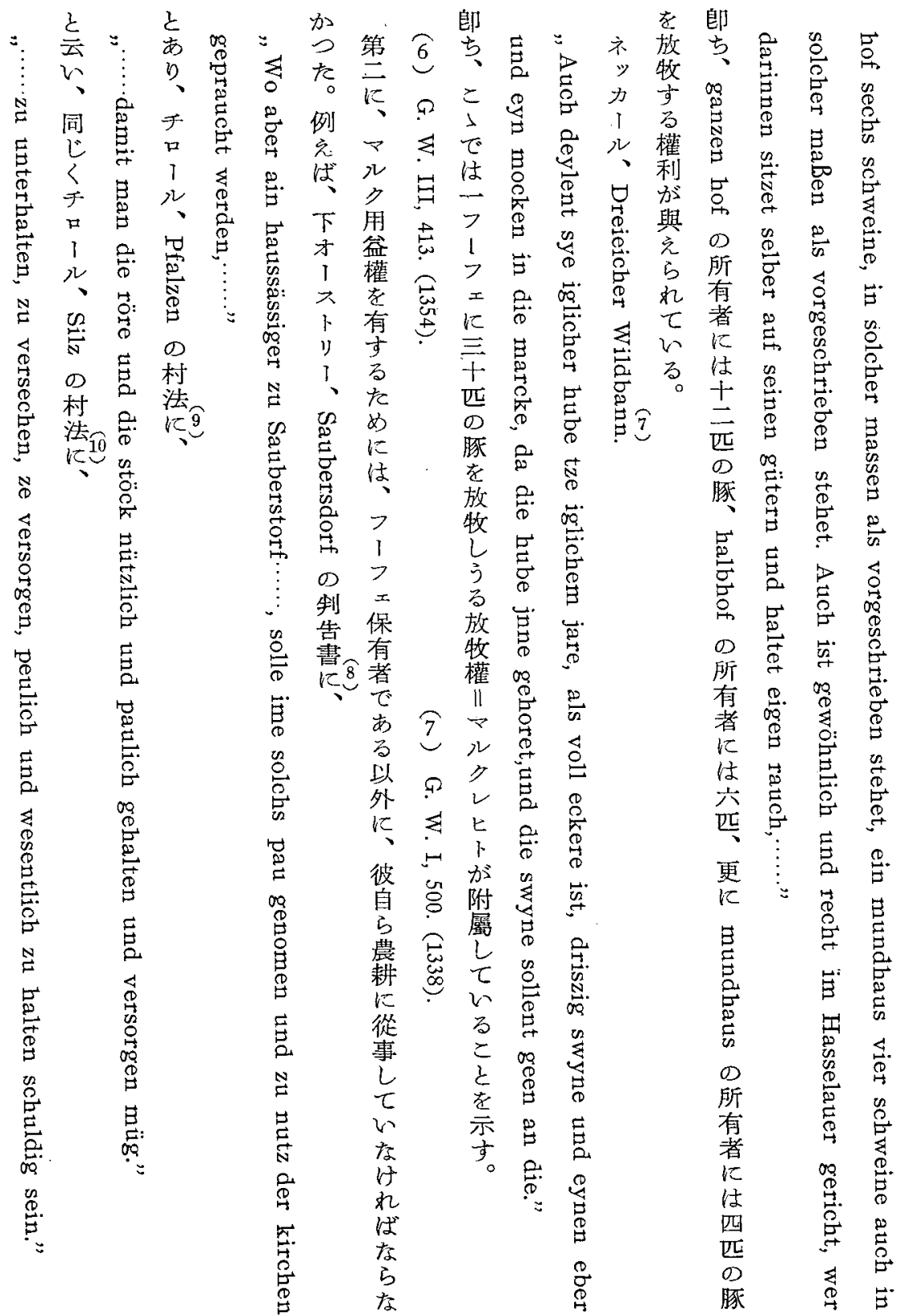




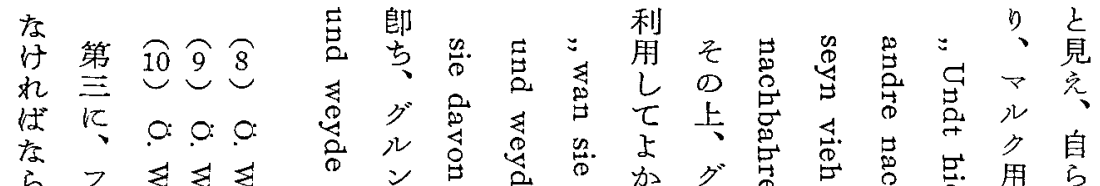

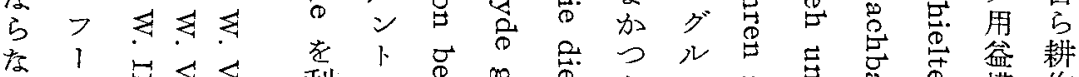

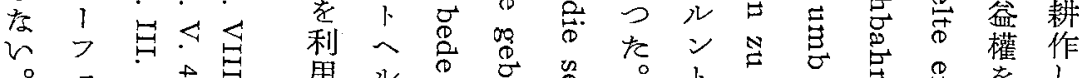

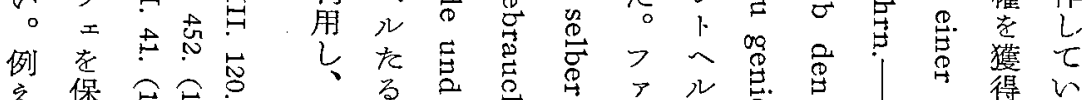

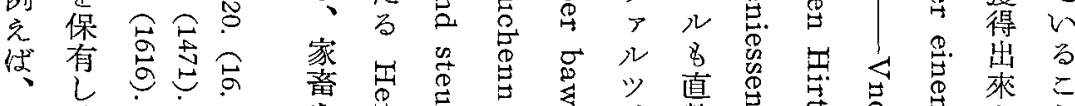

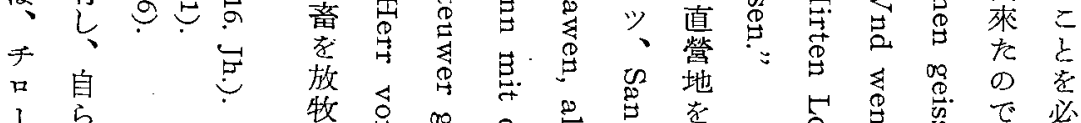

ル
農
耕

$\begin{array}{ll}\text { 贺 } & \text { に } \\ \text { 号 從 } \\ \text { 事 }\end{array}$

Е

邑芯: た

の で

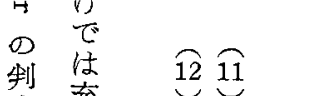

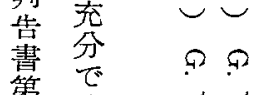

第は 引

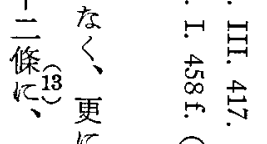

K 2

彼 兽导

身

D

獨

$\frac{1}{\text { y }}$

家

計

峃

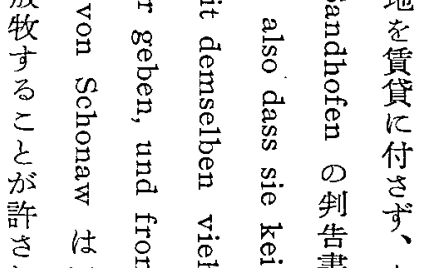

れ

た 多

あに导

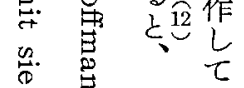

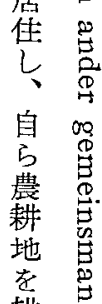

营

\&

宁限

り

标

†

官寻吕姴

导实官 た

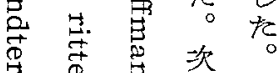

○

蛋螘学故

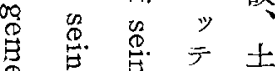

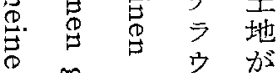

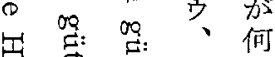

票

(1) $8.08 \%$

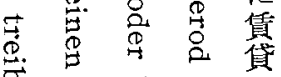

密

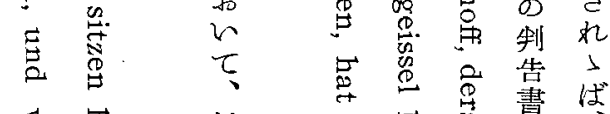

耕气事点想

L

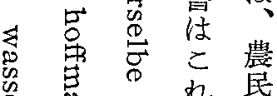

$\tau \quad \stackrel{\circ}{\circ}$

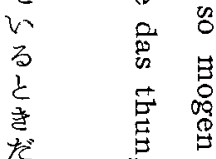

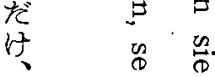

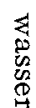

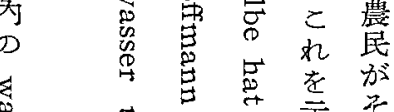

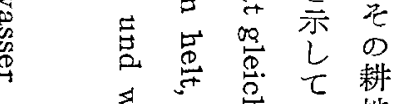

䓪 离

で

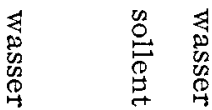

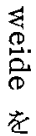

$\rightarrow \infty$ 攵 品耕

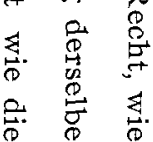

作 
, Es sollen auch kein angesessene persohnen aus diesen zwo gerichten durch andere Tyrolische landsunterthanen um gemeine schuldssachen, sowohl diese dieselben alda auch nicht verlegen oder arrestir sondern ie einer den andern bei seinem rauch suchen."

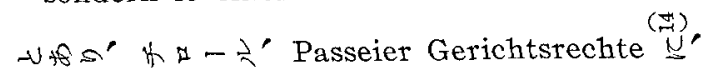

", $\cdots$, , der im gericht daselbs gesessen ist und der aigen rauch hat,....."

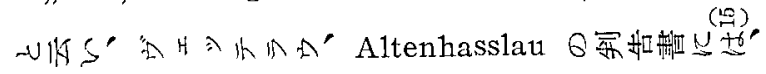

,wer in dem Altenhasselauer Gericht sitzt, wasser und weyd sucht und eigen rauch helt....."

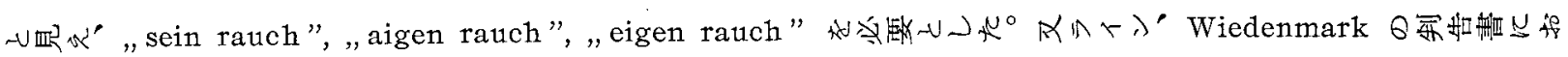

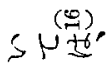

"wer da in der Wiedenmark sitzt mit feuer unndt flammen, der soll sie brauchen unndt niemandts mehr.- - Vnd soll niemandts in die Wiedemarckh fahren noch gebrauchen zu weiden mitviehe oder holtz zu haven, dann allein der mit feuer unndt flamm in der Wiedenmarckh sitzt."

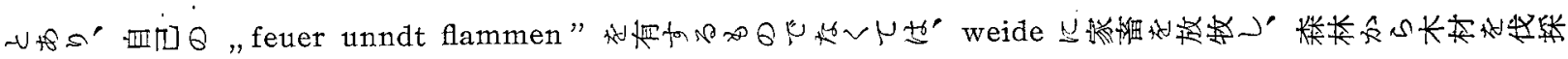

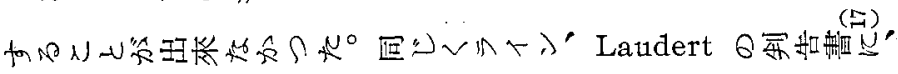

"Wer feuer und flam hat, denen erkennen sie wasser und waidt zu gebrauchen."

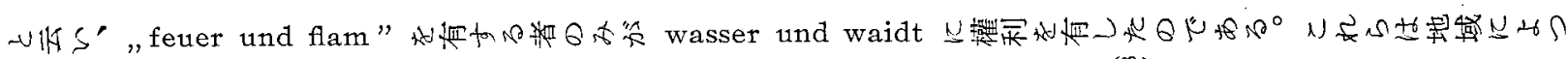
$\mu \mathbb{t}^{\prime}$, , yegklicher hussman, der in der vogty sitzt und ain sunder spis hat."; , der sein selbs mus und brot isset."; , das nieman solhussen vsserthalb etters." 6 둔 ${ }^{\prime}$, ain sunder spis" th $S$, sein selbs 


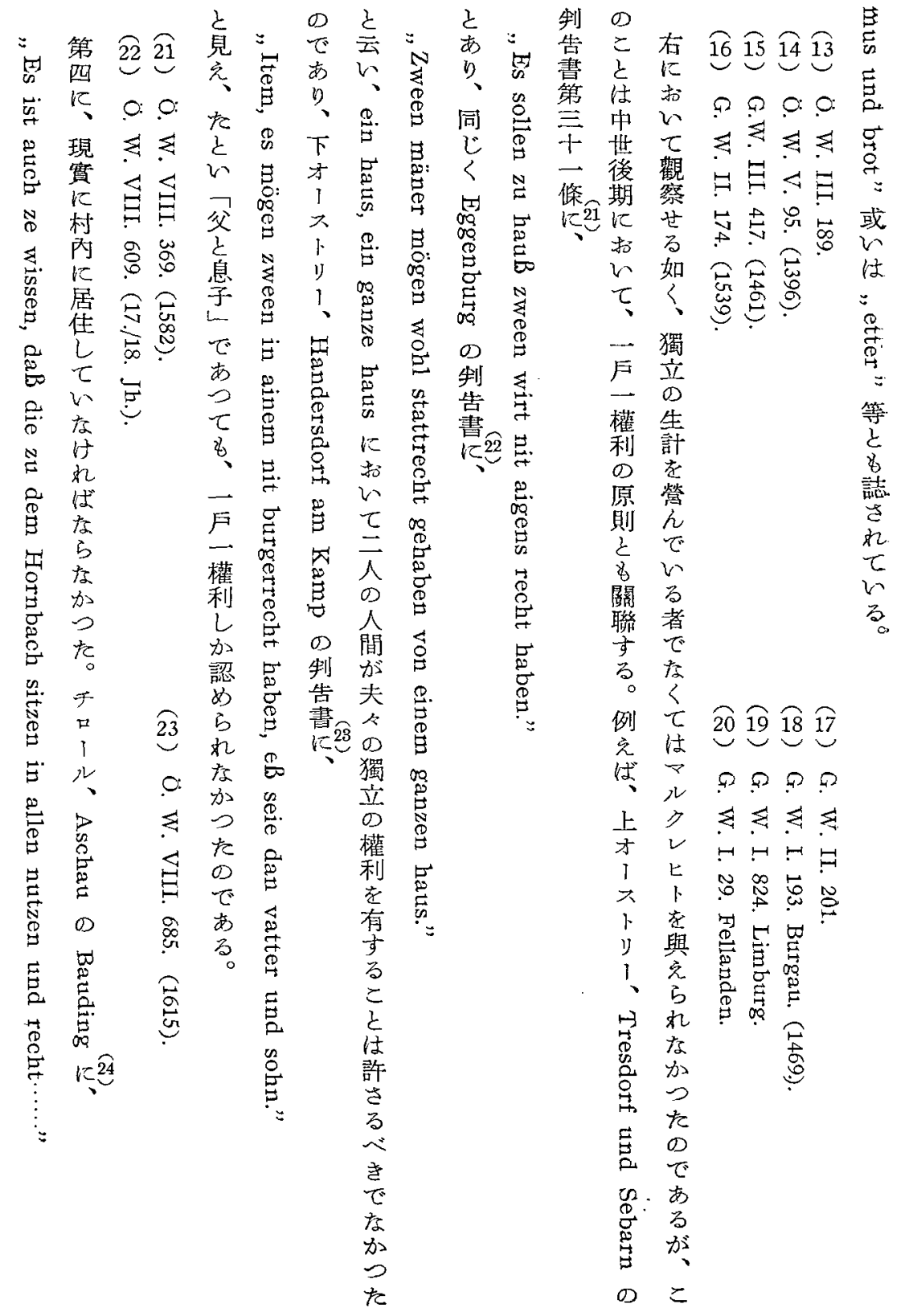


中世後期に於ける Markrecht の特質

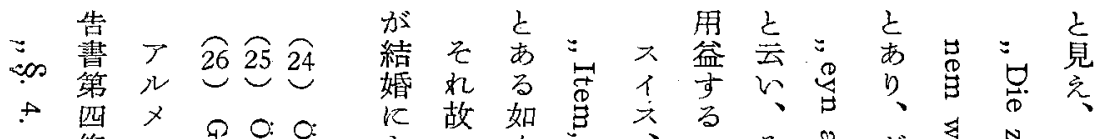

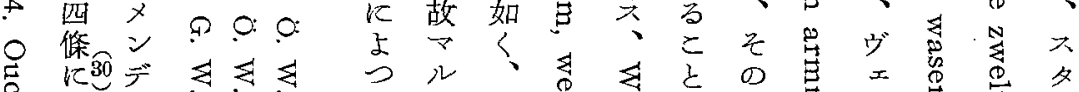

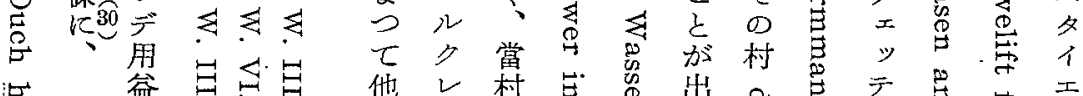

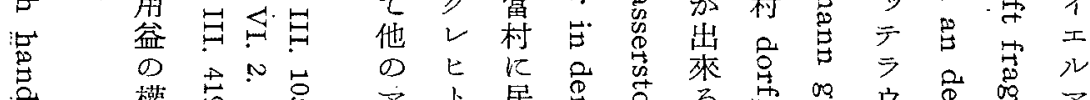

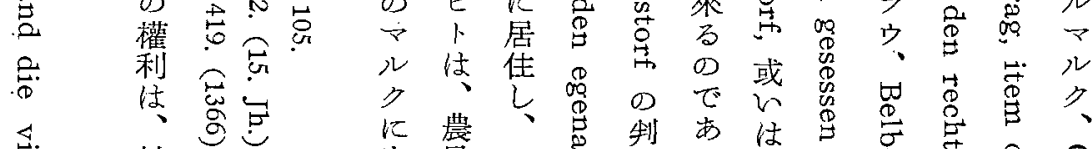

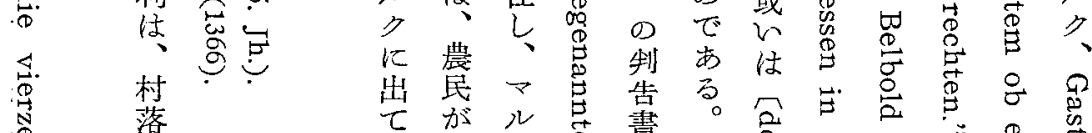

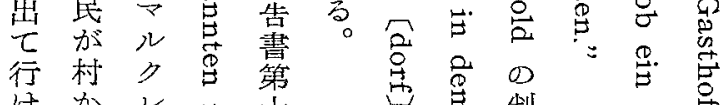

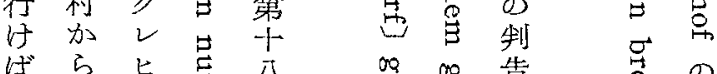

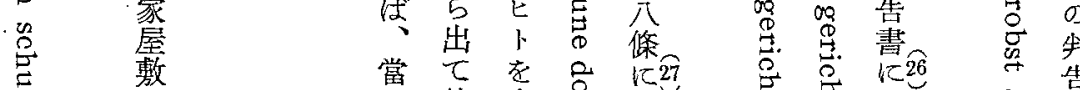

"to

急

窟

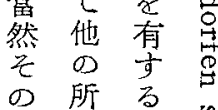

$\frac{\varepsilon}{8}$

閐

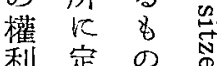

利定 $の \stackrel{\mathbb{\infty}}{\stackrel{N}{*}}$

住集

え わ市市

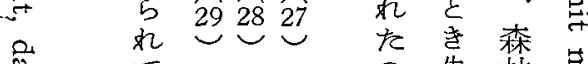

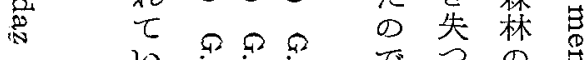

.

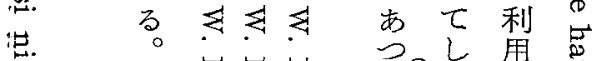

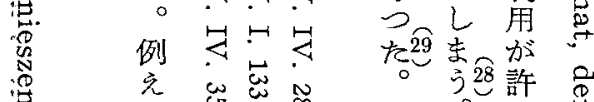

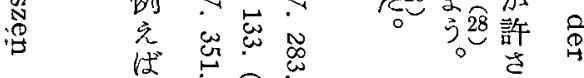

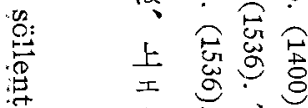

艺齐落

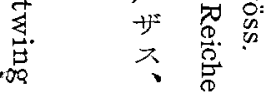

吉出

:

娄

同市

樣厺嵒

\begin{tabular}{lll}
$k$ & 0 & 0 \\
$\nabla$ & & 0 \\
\hline
\end{tabular}

少

t)

有寄

万焉共

婦昰地

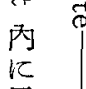

居

住

ᄂ

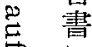

点 


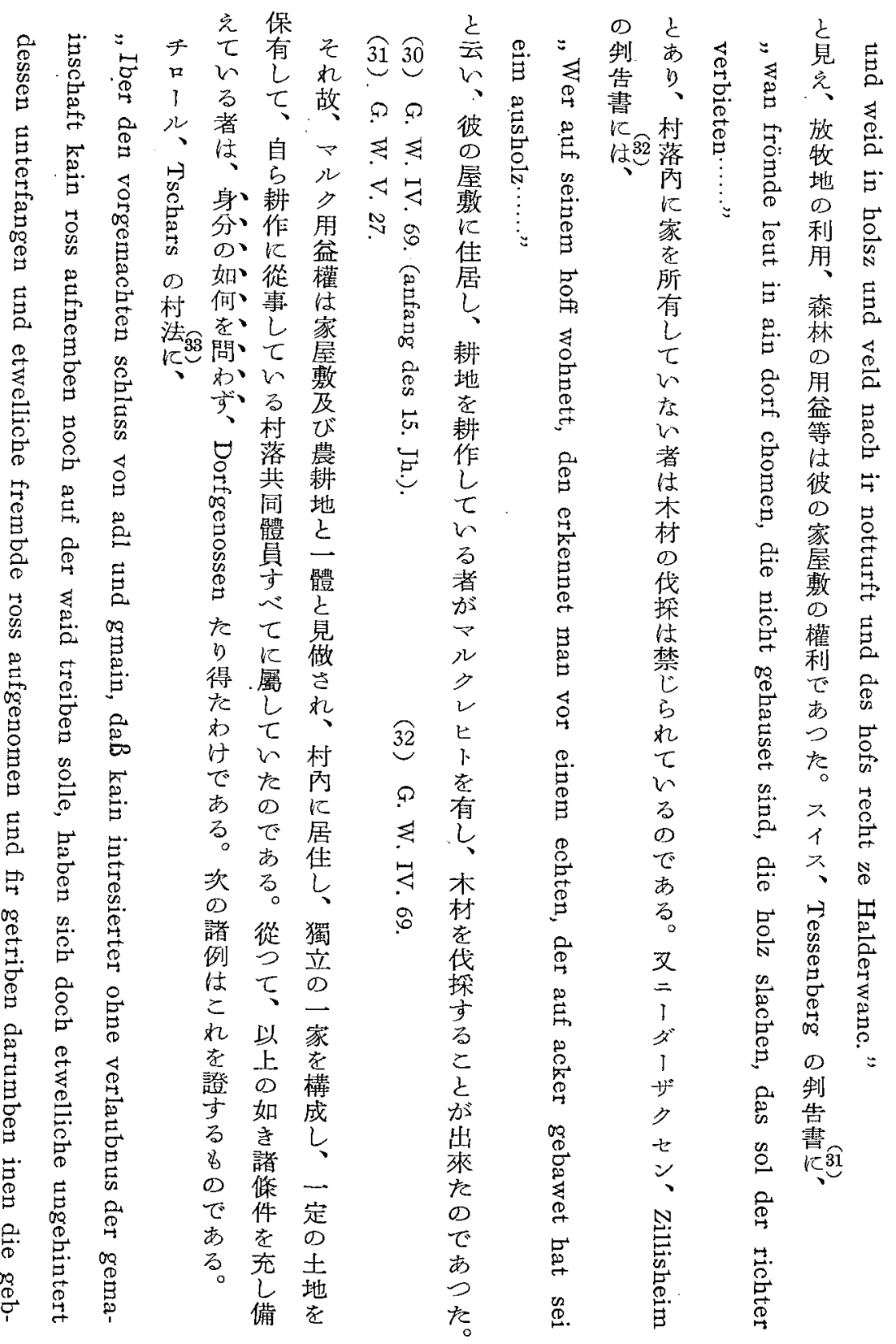


irente und in vorigen schluss gemachte straff geschepfte worden ".

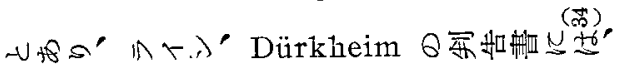

,$\ldots$...sollent die ganz gemeinde, priester, edel und alle andere sesshaftig zu Dürkheim bi ein ander sin, đie da wald, wasser und weide gebrauchen."

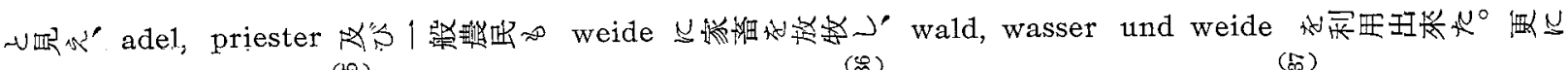
" er sei edel oder unedel "; , alle merker edle und unedle", ,, es wäre edl oder uned1"; , er von adel

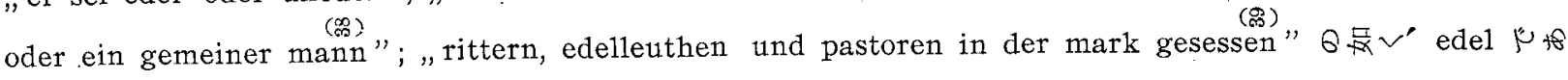

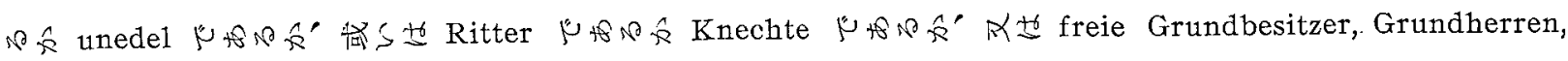
Ministerialen, Vasallen
(m) Ö. W. IV. 322. (1642).
(师) G. W. III. 412.
(ल) G. W. I. 787. (vor 1530).
(孞) O. W. VII. 51. (18. Jh.).
(m) O.W. IV. 7. (16. Jh.). Glurus; V. 25. (1371). Par-
$\left(\begin{array}{l}\infty \\ m\end{array}\right)$ O. W. VII. 143. (17. Jh.).
tschins.
(i) G. W. III. 491. (1493).

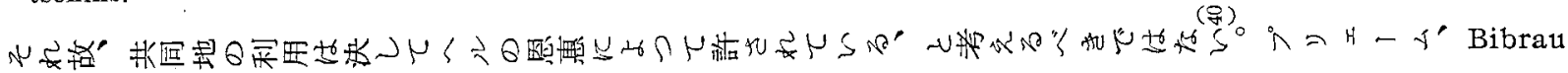

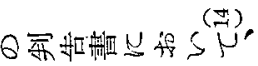

"Wir wysen uff unsern eid Bygermark walt, wasser und welde, als wide als sie begriffen hat, den merkern zu rechtlichem eigen, und han die von nymand $z \mathfrak{u}$ lehen, weder von konige odir von keisern, noch von burgern oder von steden, dan sie ir recht eigen ist." 


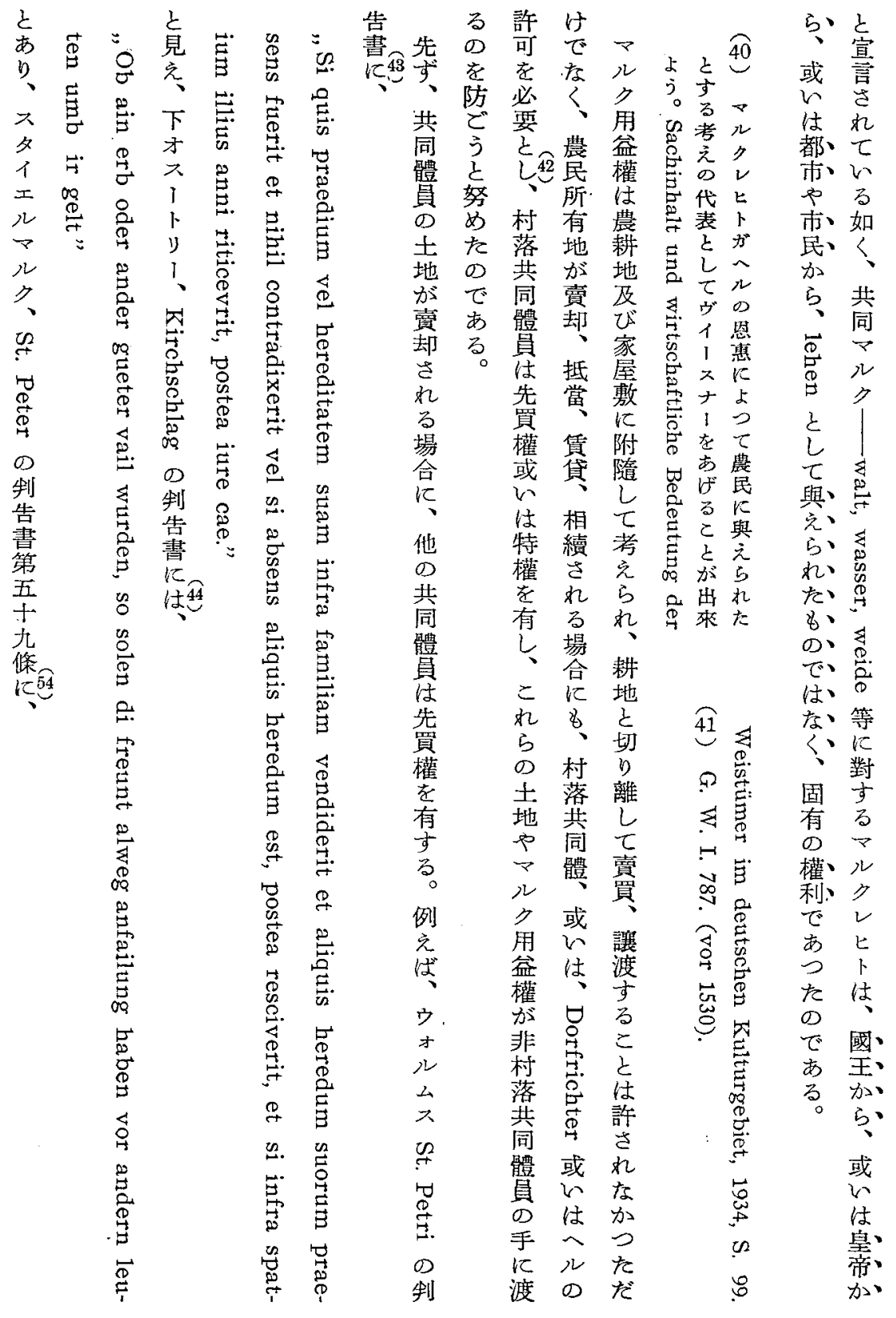


, Item wer seine grünt verkaufen will, es sei hueben, äcker oder wiß madt, der sol die anfailen sein negsten erben ......"

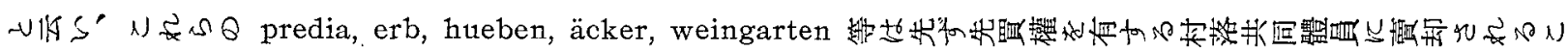

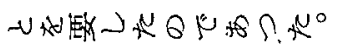

(₹) O. W. VII. 124, 169, 499, 647, 773, 936, 1016 etc-

(ষ) Ö. W. VII. 9. (16. Jh.).

(?) G. W. I, 805. §. 6. (1024).

(\%) Ö. W..VI. 269. (16. Jh.).

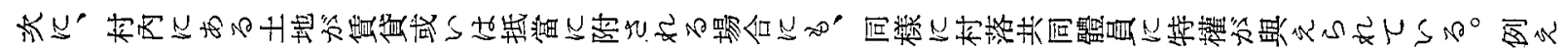

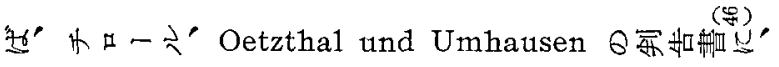

"wenn einer von notturft oder armuet wegen" muesset sein wissenradt oder acker versetzen oder verkümmren, den sol er am ersten seinen nachpauren anbieten $\cdots \cdot$... davon es nicht aus der gewer käm und sol es auch nicht lenger verkümmern, dann auf 5 jar mit des kamrär oder des treiben an meiner. frauen stat wissen, das es dem gotshus nicht verirret oder enpfrömbt werde....."

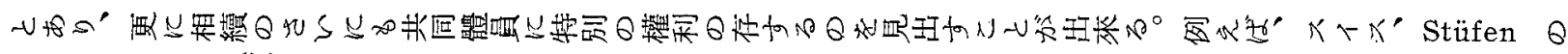

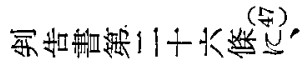

„…..stirbt ein hobmann, da man niemant erben veiszt, den sol der nechst nachbar erben....."

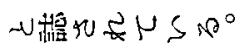
(\%) Ö. W. III. 76.
(\&) G. W. I. 47. (15. Jh) 


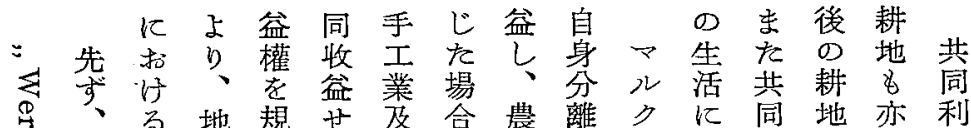
、る 地規せ文合農離名に同地亦利 、大こ域制しび々民局不地及同用

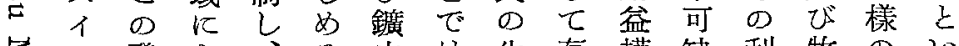

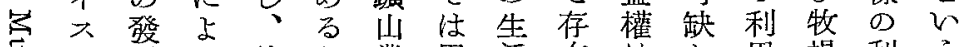

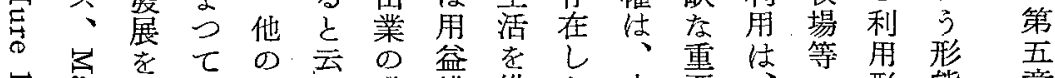

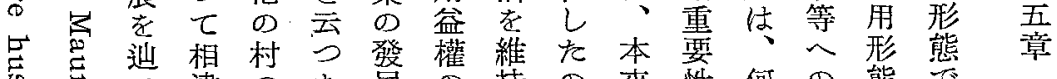
怘 怘制見、或歌共模る は 屋8 \&同に同同

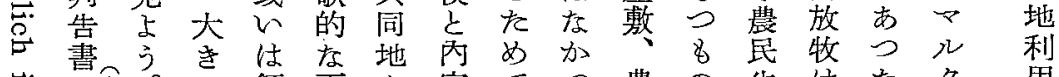

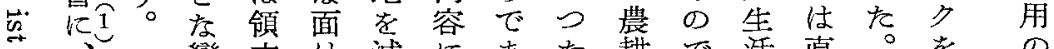

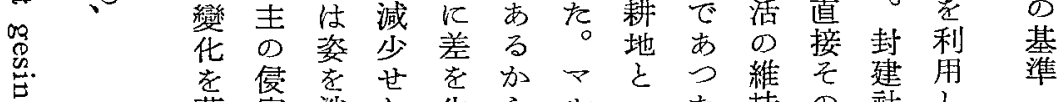

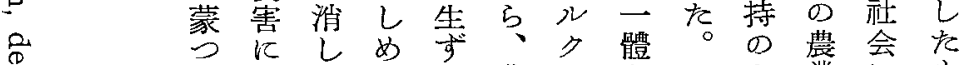

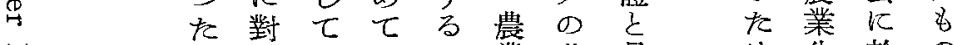

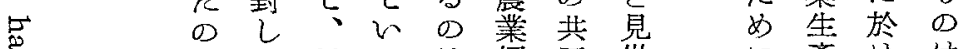
$\rightarrow$ でて村るは經同做济けは

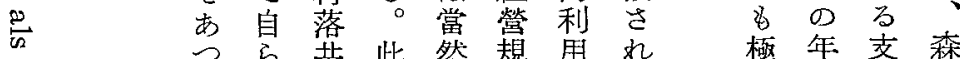

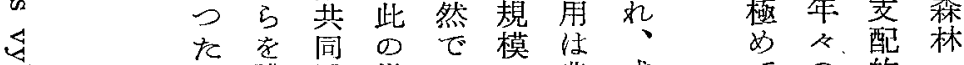
護體樣市に 農 或 ワろはなる扔業い

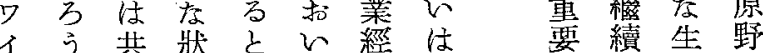
ズ亡同態思て營農店を產 卜し體心 わ比を耕意可は牧 ウた自下犯較年地義能農場

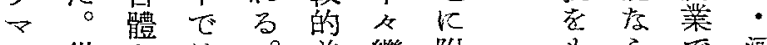

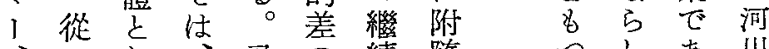

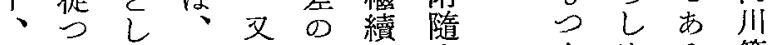
村てて あ中少可古为める 等 法、、り世存能る 等 共 共 餘 後方存名基云限 を同通る期つ ら の 市礎わ口 中地

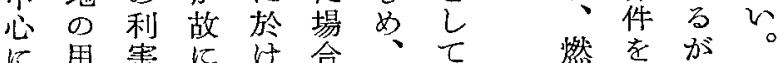

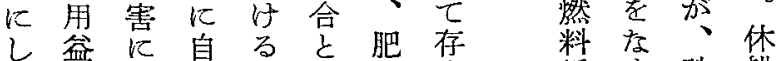
乙 權 結 由植、料在 探卞殊

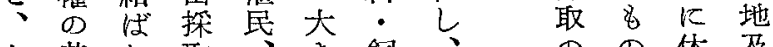
十基独取会司、 一準、開な料決如な耕改 世名自許墾相を地 紀時 らしの湋使て はで、穫

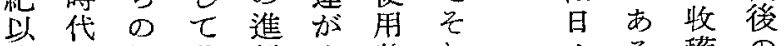
降飞用共行生收机文穫口 
中世後期に知ける Markrecht の特質

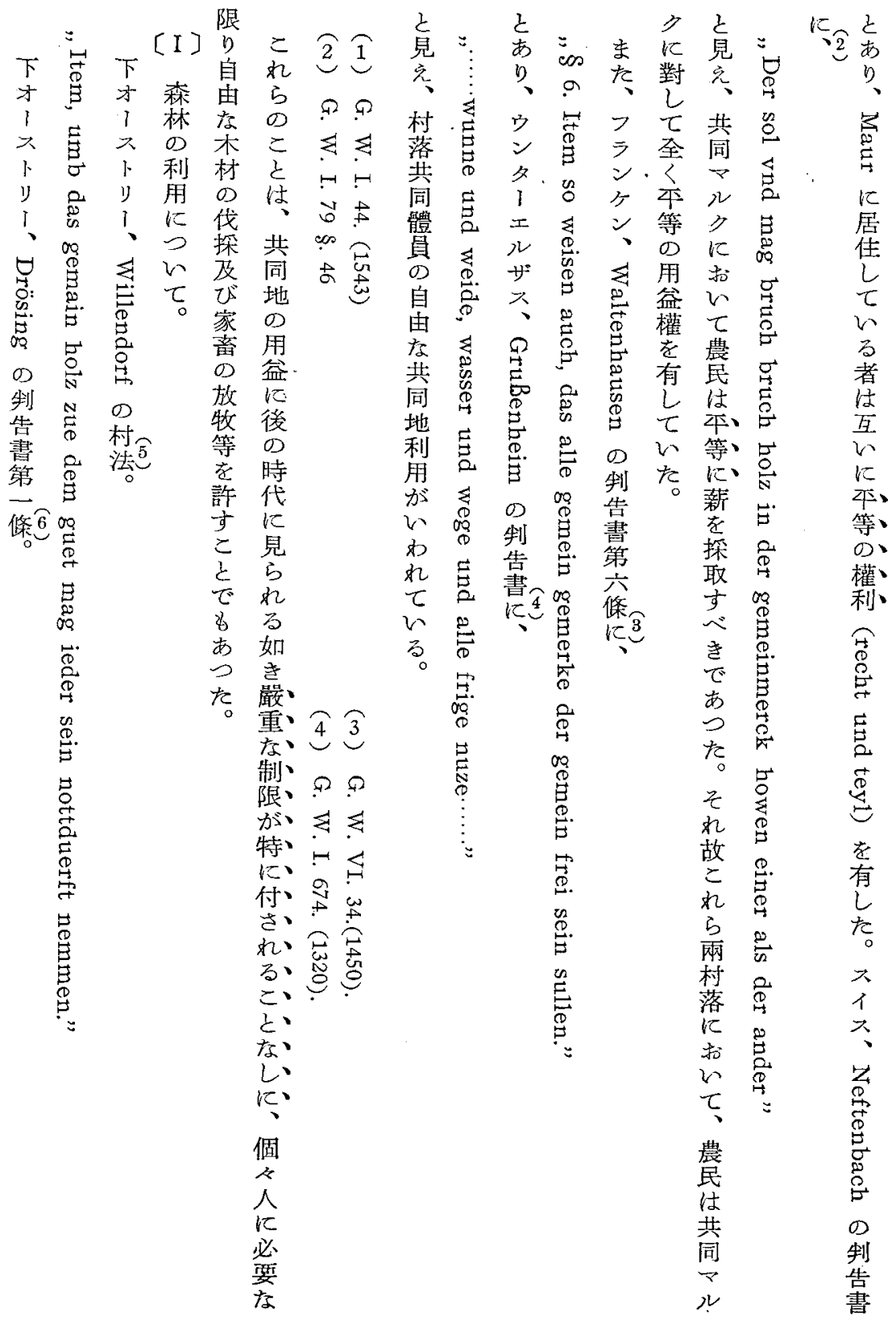


„Erstlichen, daß darinen ain ieglicher hausgesessener mag darauß nemben sein notturft holzwerck, zu welcherlei notturft daß sei."

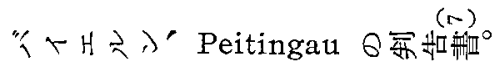

"Wie ferr die gmain gat in die saB, so soll man ein slegel nemmen, und soll in tragen in den wald, und soll in lassen walgen, als verr der schlegel herab walgt, als verr mag einer wohl hauen im selber on schaden."

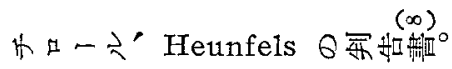

...., , aber zu notturft irer heuser haben die nachperschaft in Tiliach ausserhalb der panwäld und federschachen mit holzen, wunnen und waiden gehalten treulich und angefärlich, wie von alter her komen ist."

$K \vdash K^{\prime}$ Langaten 6 军和船 ${ }^{\circ}$

„, die gueter sullent davon ir notdurft haben ze husen vnd ze brennende vnd ze solichen dingen, du dien guetern notdurftig sin."

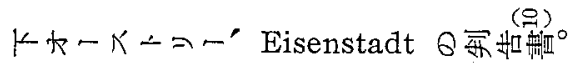

"Item, in den wälden soll man guete ordnung halten und welchem underthan holzzu hauBnotturft bewilliget......"

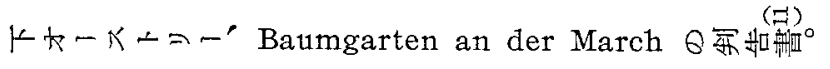

"Wem sein nọtturft zimerhọlz zue pawung sẹnes haus erlạbt wurt und davon vill oder wenig ubẹ 
中世後期に於ける Markrecht の特質

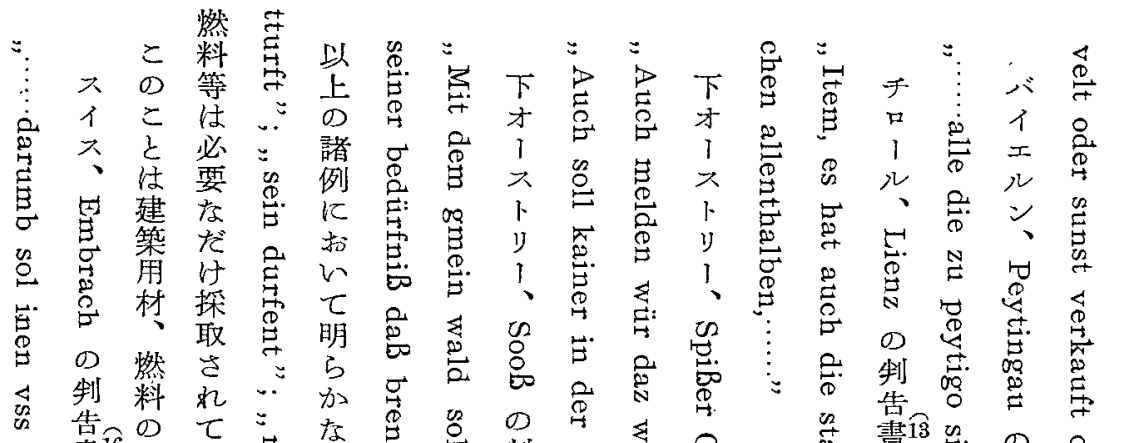

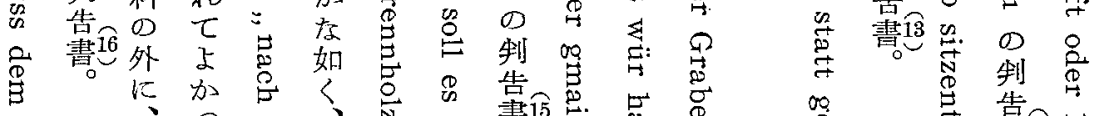

$\begin{array}{lllllll} & & & \\ 0\end{array}$

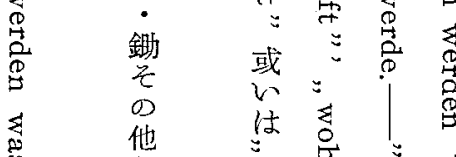

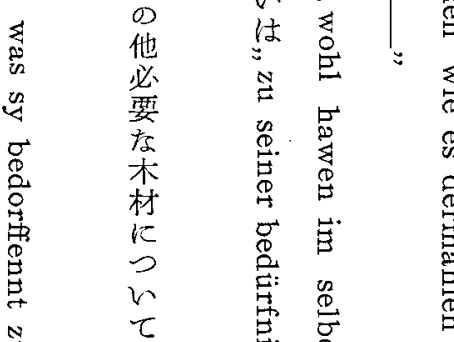

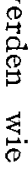

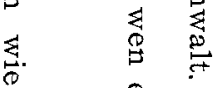

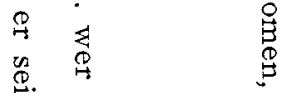

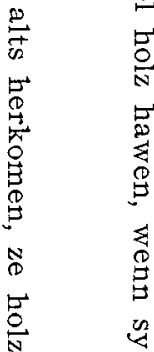

2.

N $\quad \stackrel{5}{\square}$

今.

虫. 昜:

芯: $\quad \begin{gathered}\tau \\ 0\end{gathered}$

象

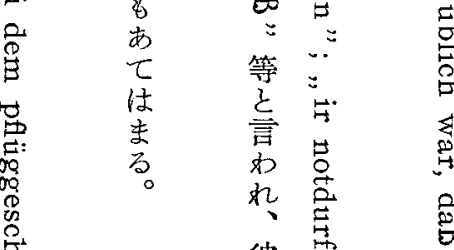

$\stackrel{\vec{B}}{\mathrm{~B}}$

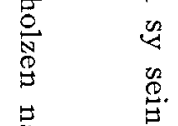

点彼营

万 ‥

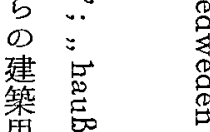

角要

材 品

焉

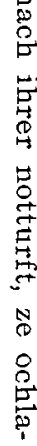

量 


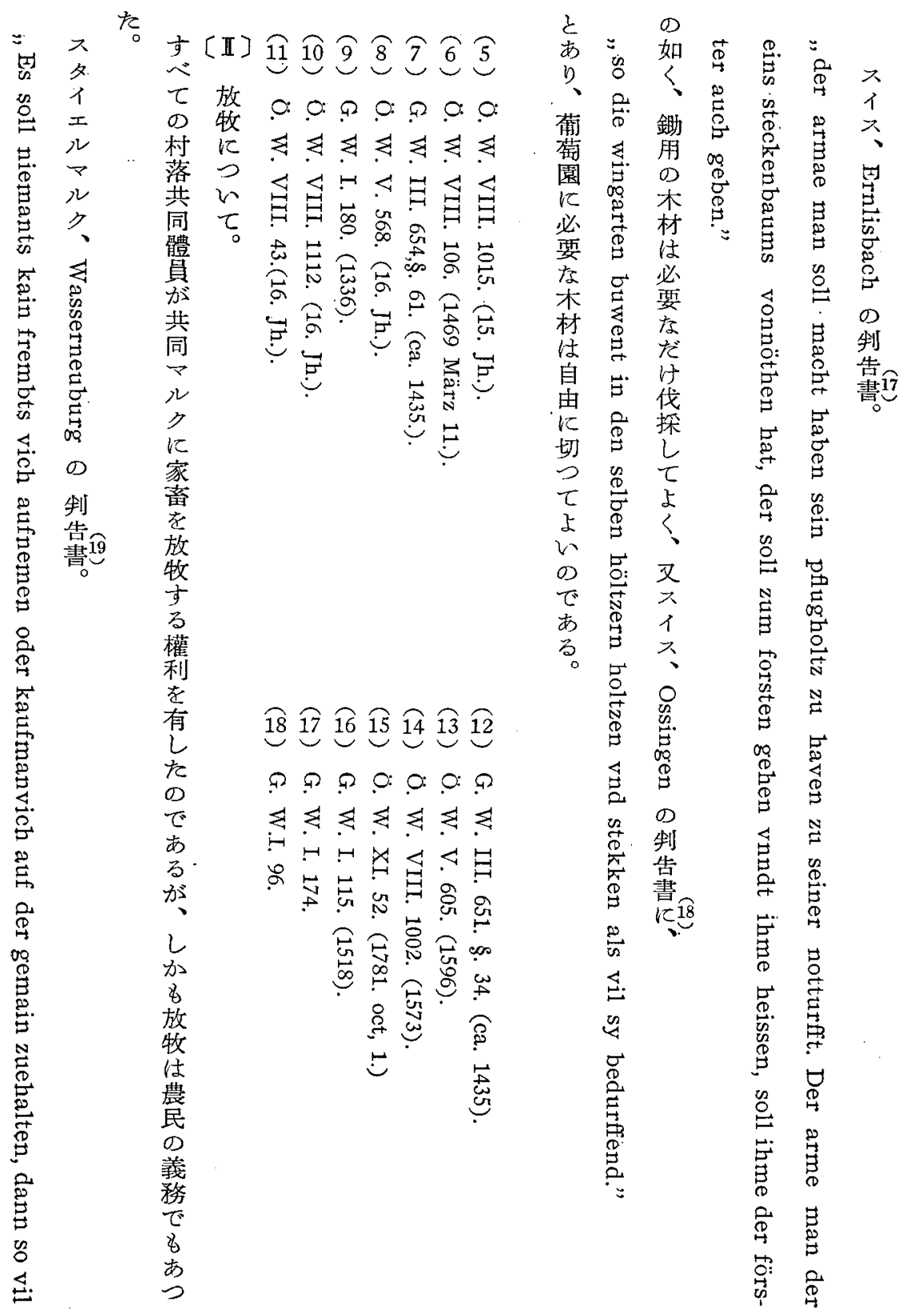


中世媵期に於ける Markrecht の特質

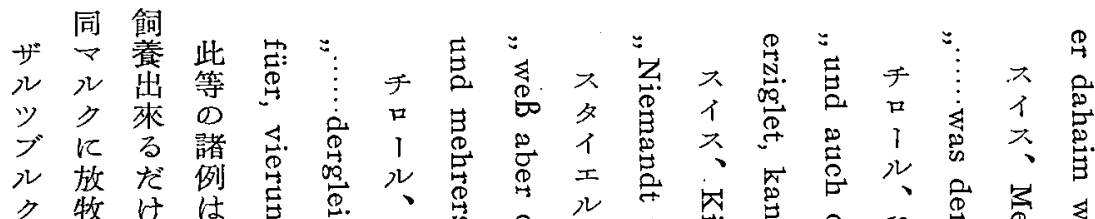

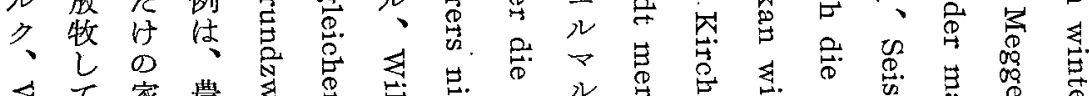

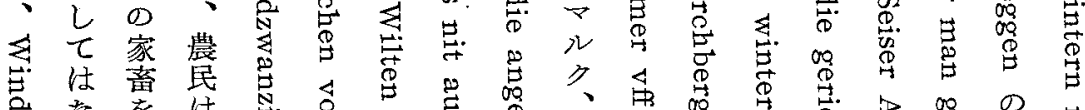

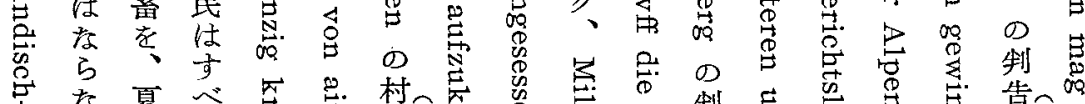

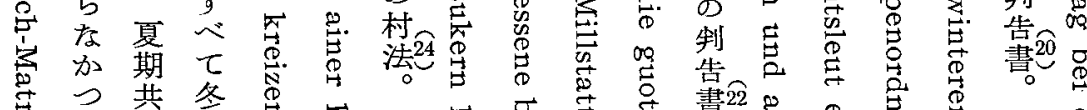

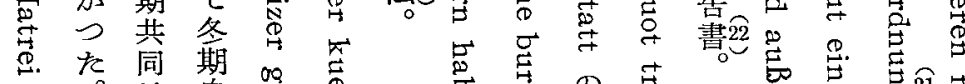

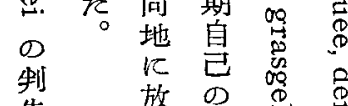

告 放

書25 牧

乙

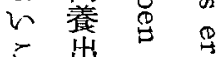

之 來 号官:

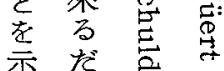

于

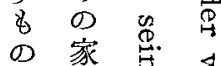

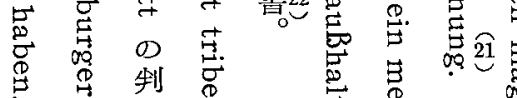

葛 定

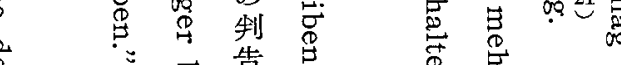

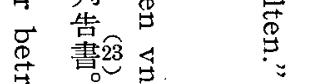

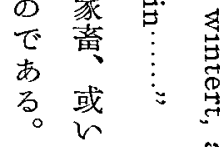

書23

䒠

D

そは

今

告

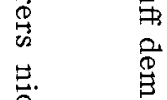

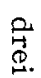

:

$\stackrel{2}{\stackrel{2}{+}}$

常 $\quad \stackrel{5}{8}$

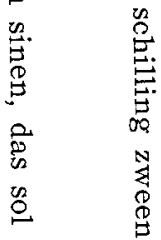

\% 莺

召

है

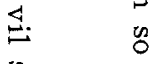

营

邑

$\stackrel{9}{9}$

泀

号

岂总

水自

故

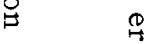

䓀

空.

次去地

見 D

吕

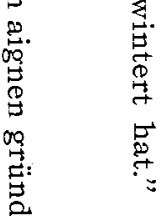

る 和

如 $\underset{⿱ 乛}{\stackrel{5}{0}}$

他

人

(

点

家 D

童

を 冬

共 期

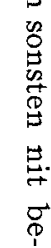

离

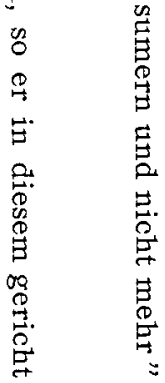




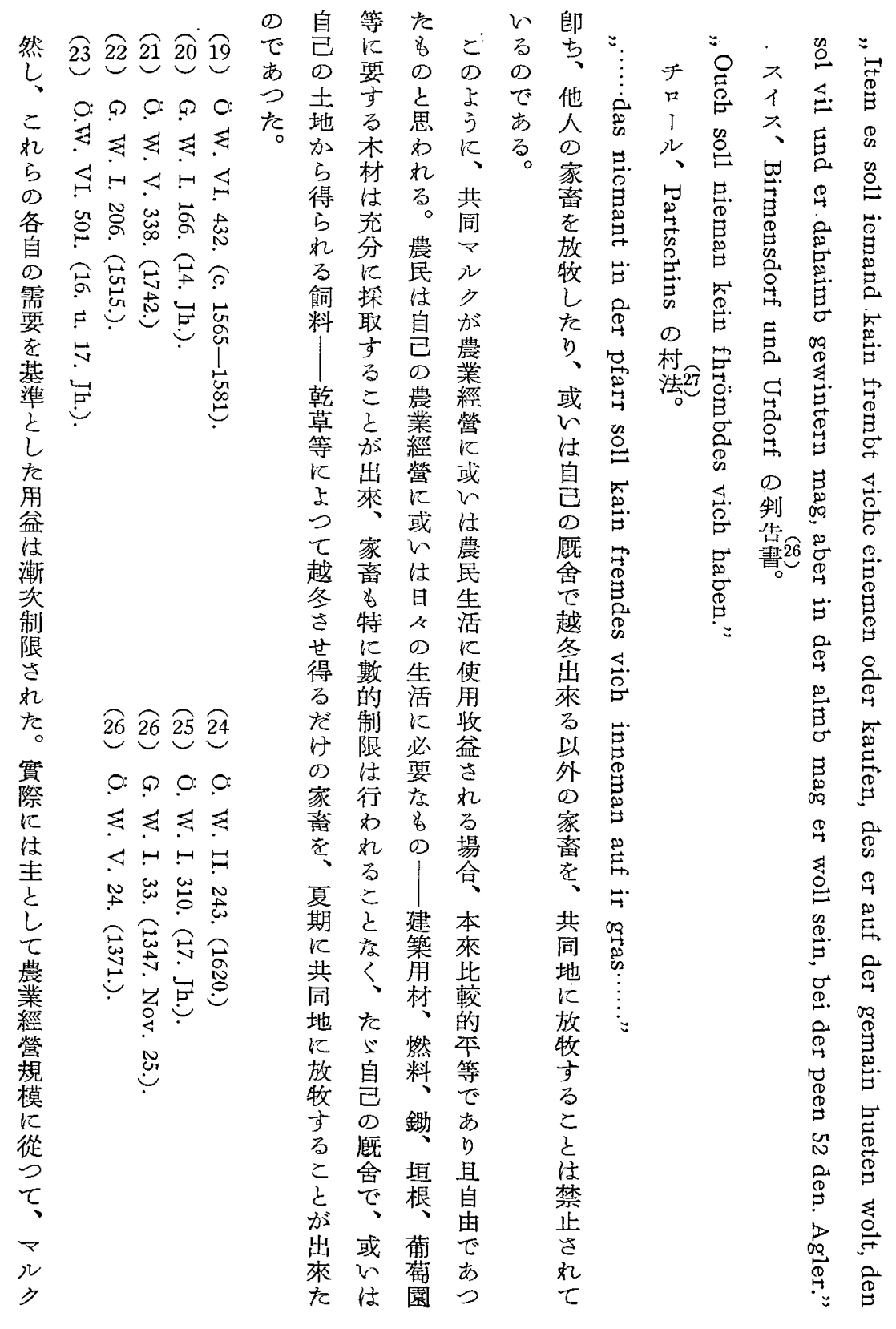


中世後期に於ける Markrecht の特質

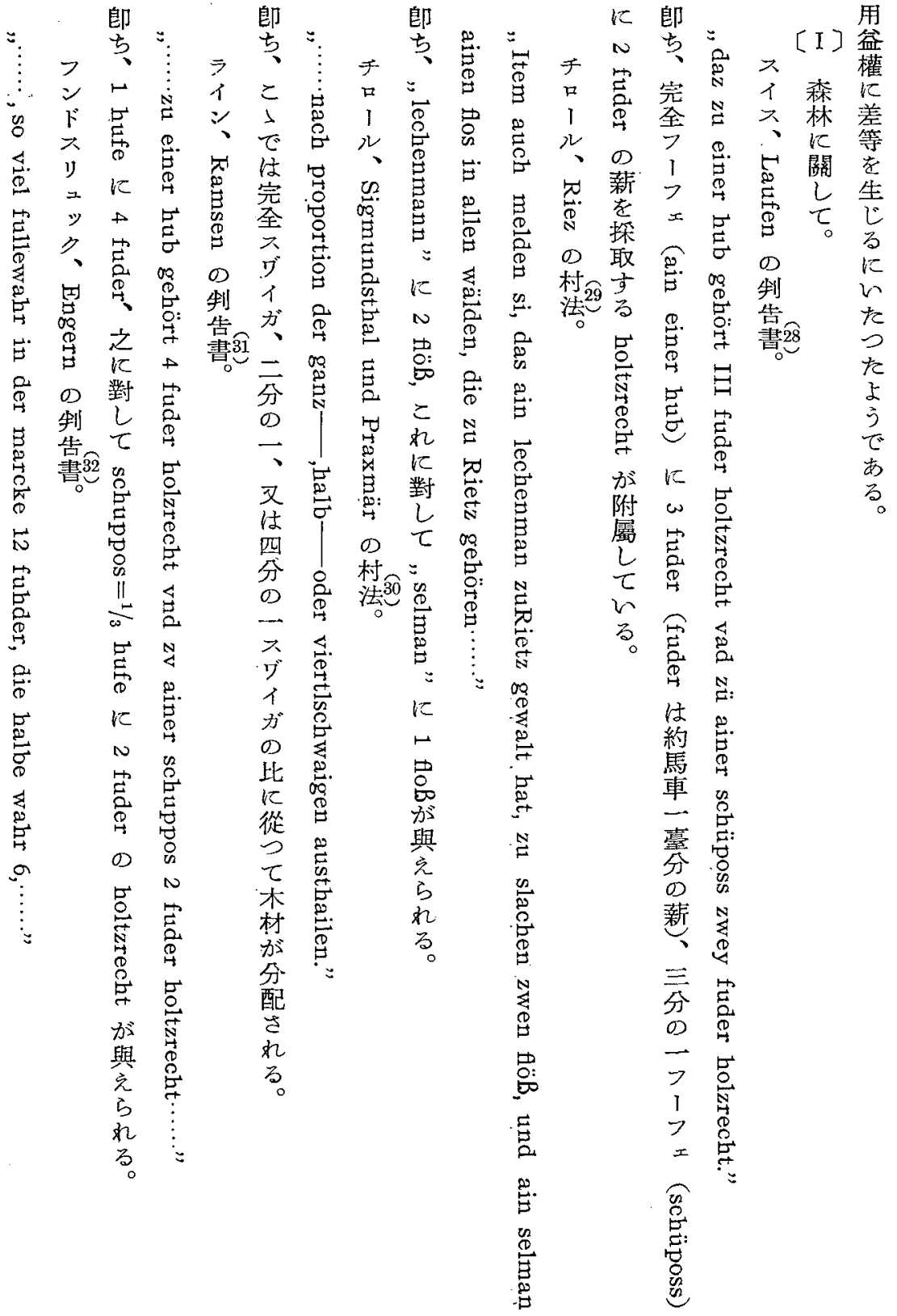




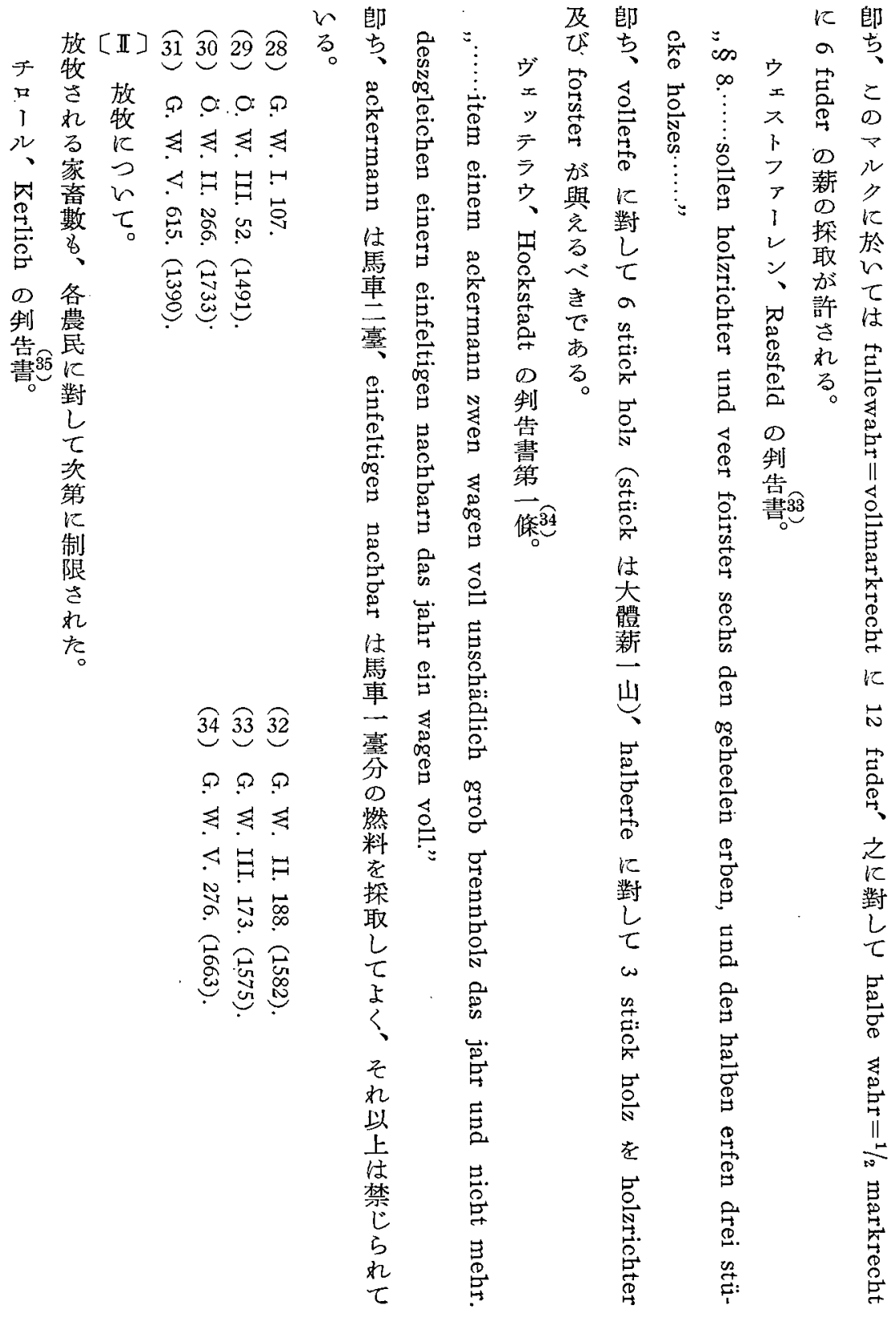


中世後期に於ける Markrecht の特質

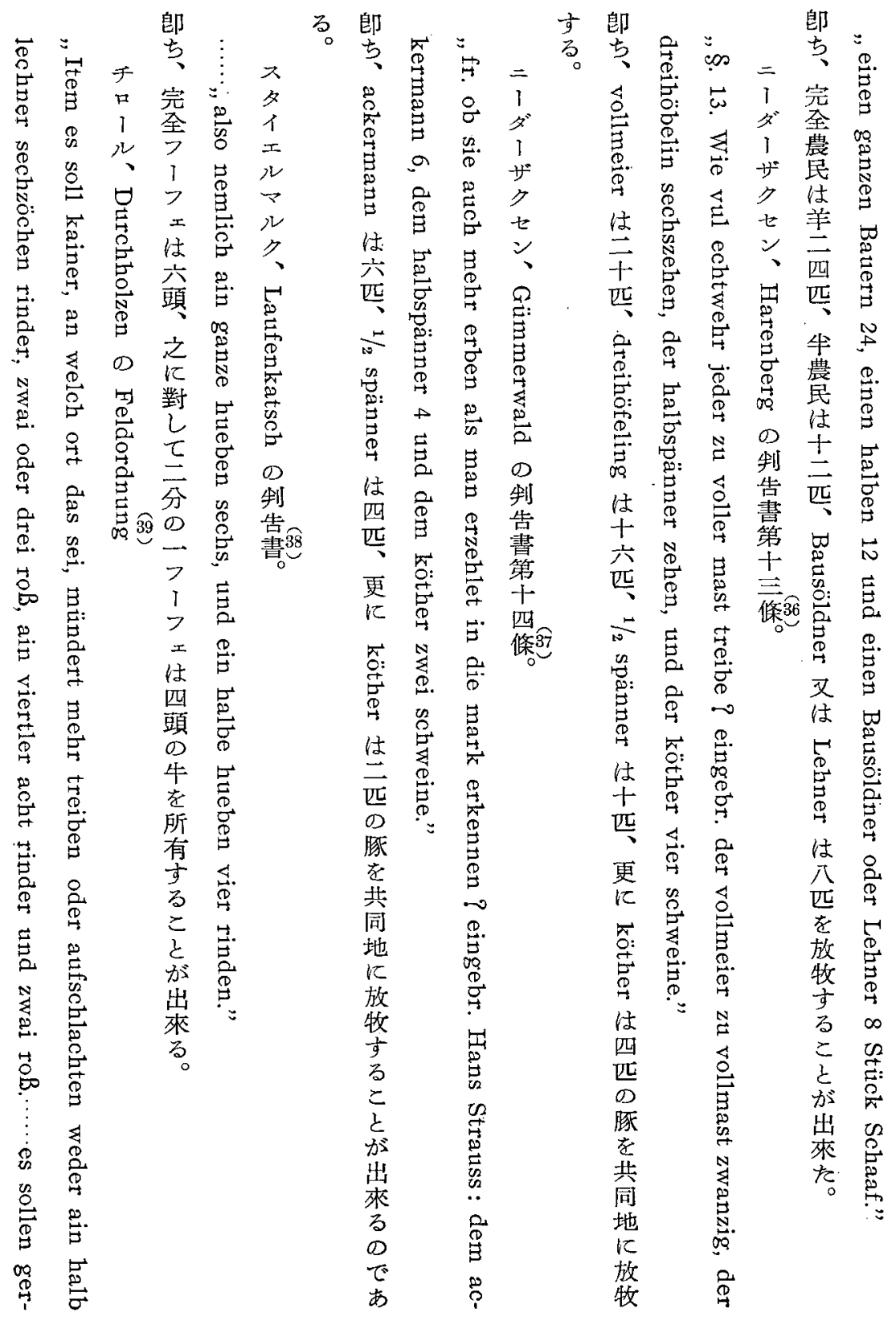




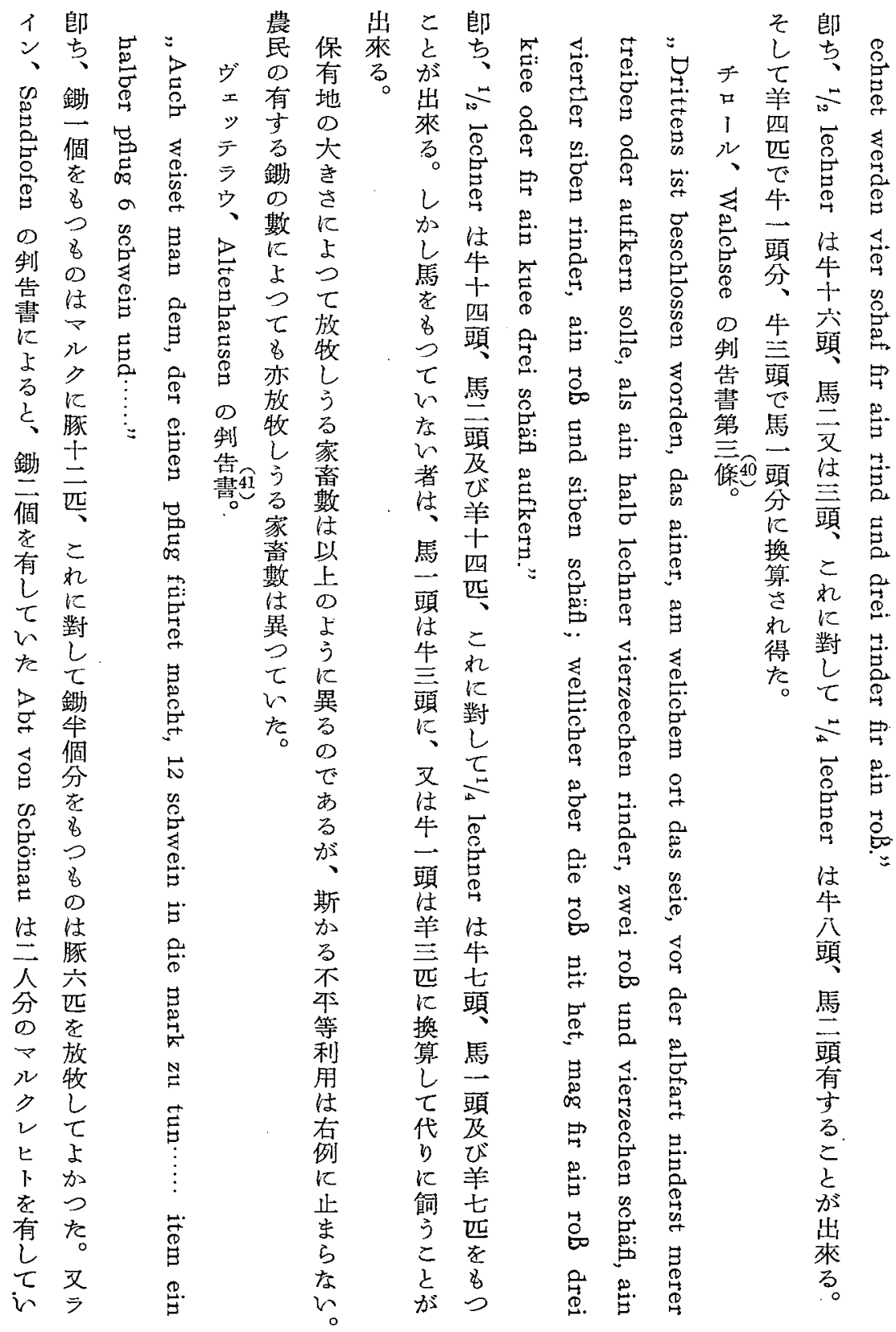


中世後期に於ける Markrecht の特犋

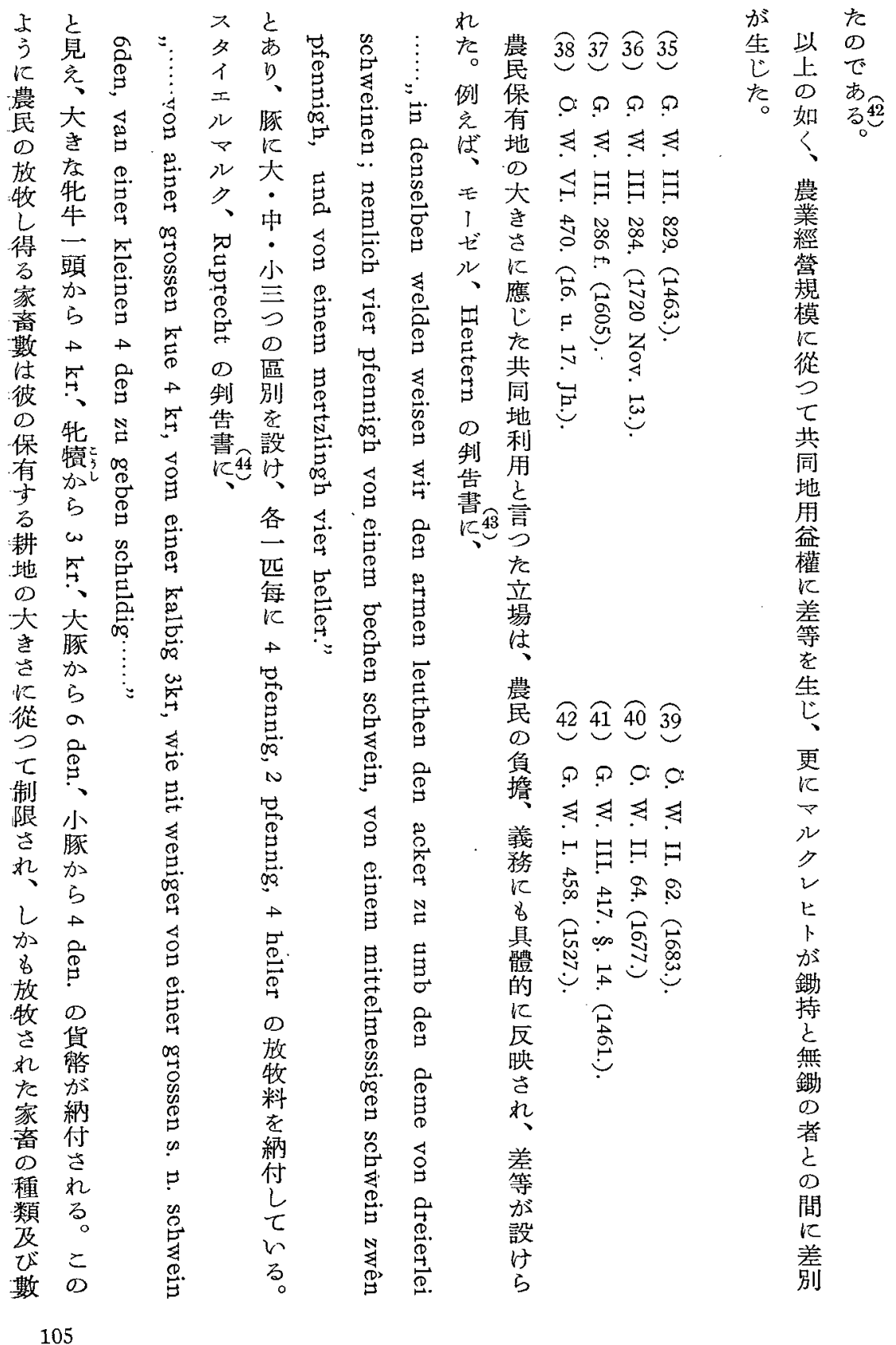




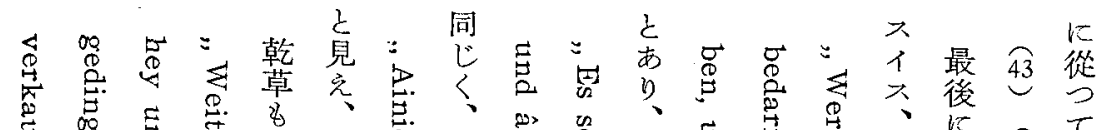
蜼 丞造

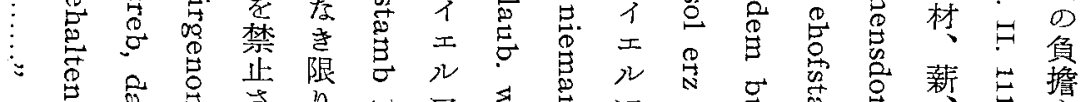
总

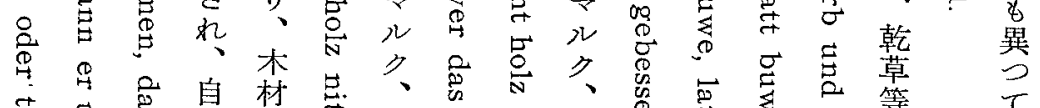

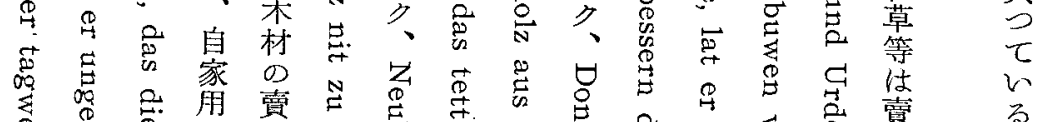

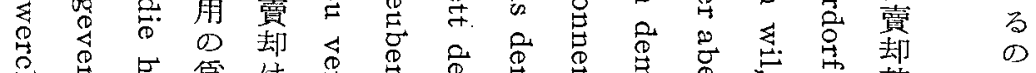

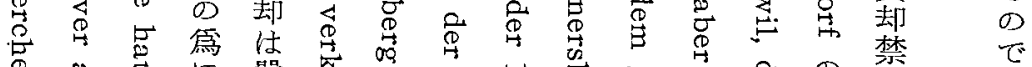

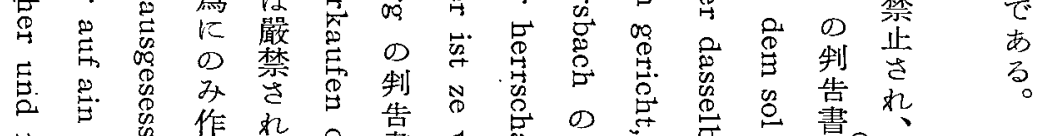

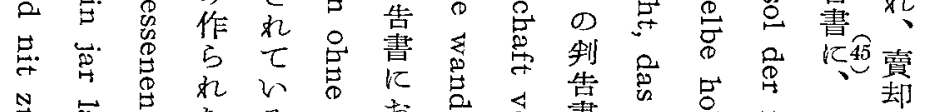
N

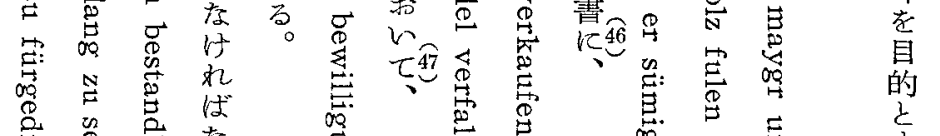

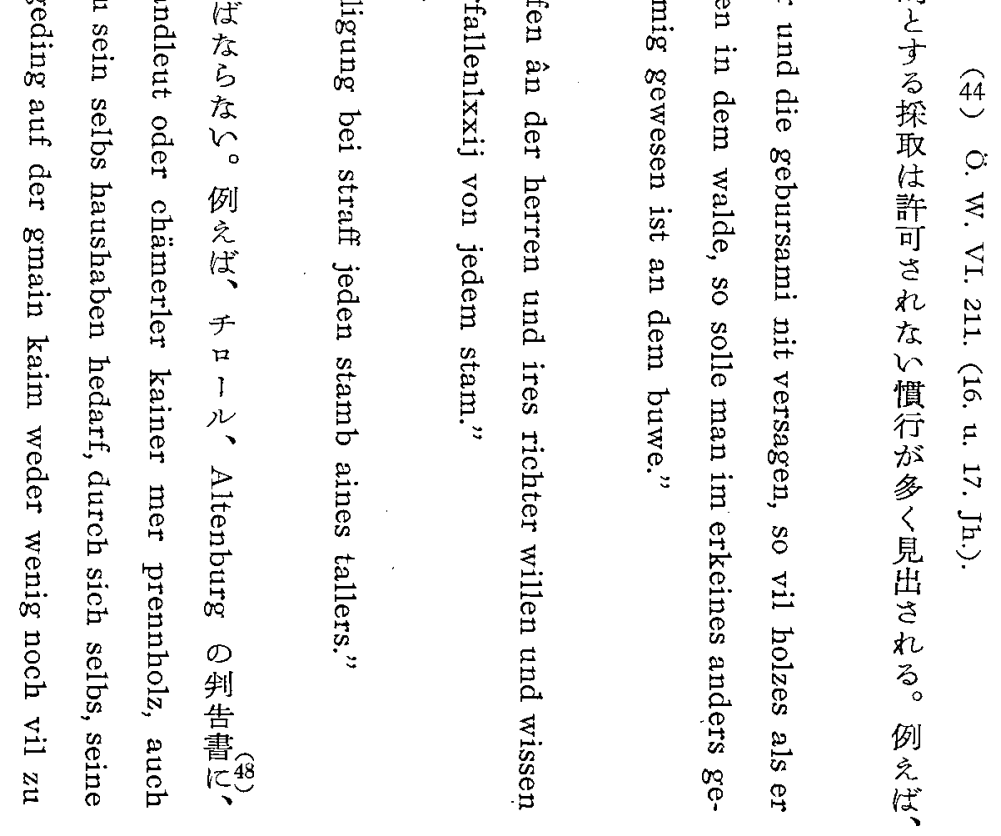


中世後期に於ける Markrecht の特質

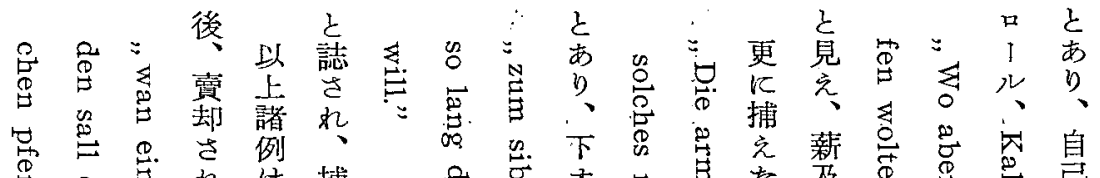

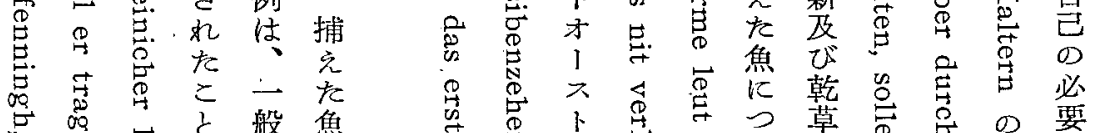

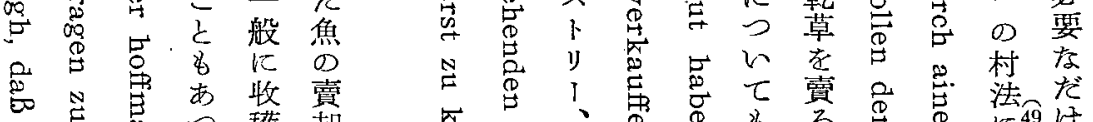

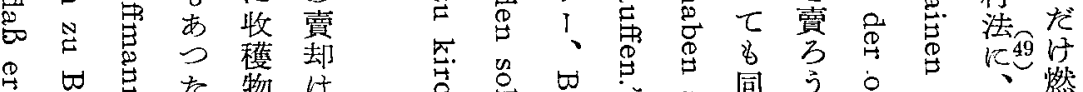

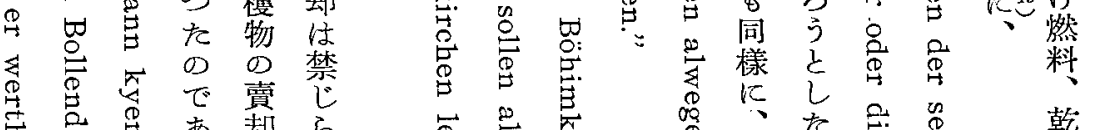
号令あ却ら

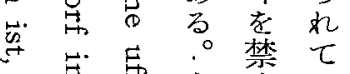

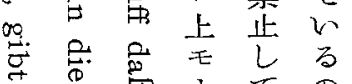

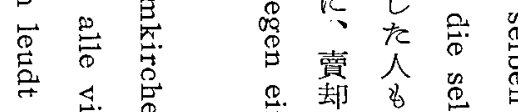

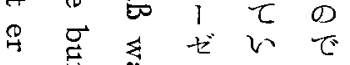

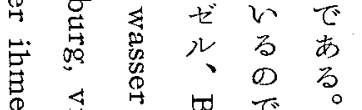

芦. 䒿 壱

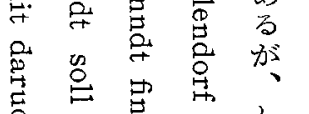

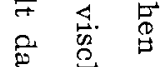

幹

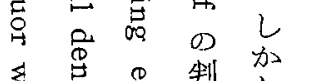

过

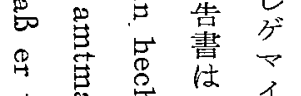

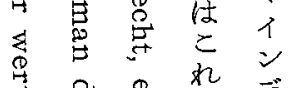

点㣽尽 れを 或

岕苍总京 或

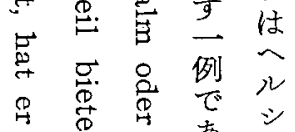

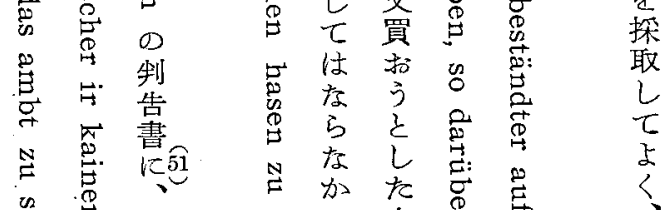

苛

今 $\stackrel{\oplus}{口}$

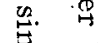

$\rightarrow D$ 人

曽参.

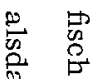

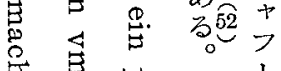

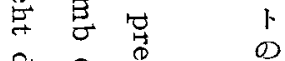

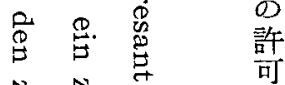

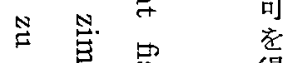

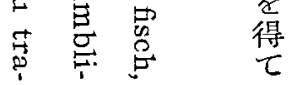




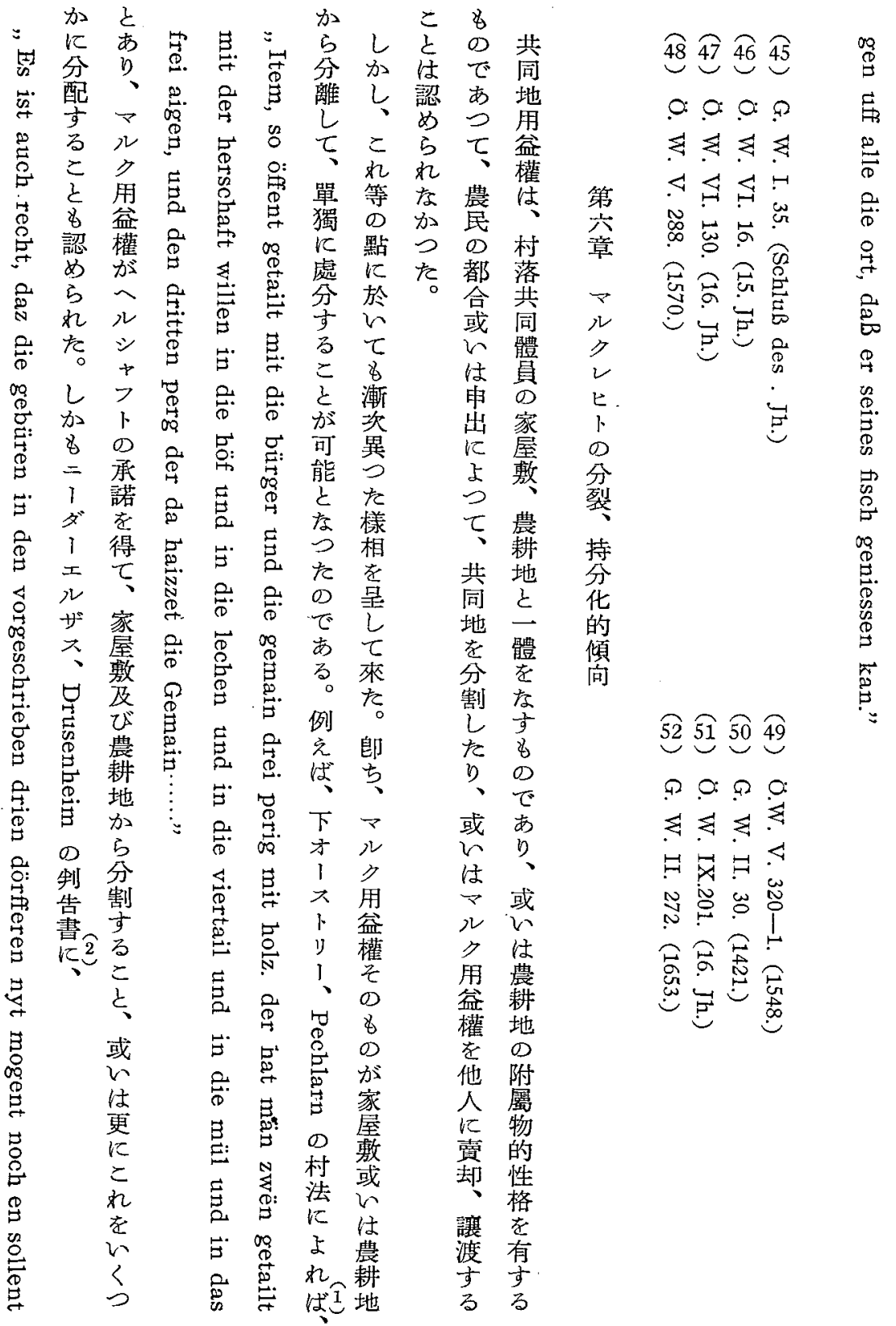


中世䉄期に於ける Markrecht の特質

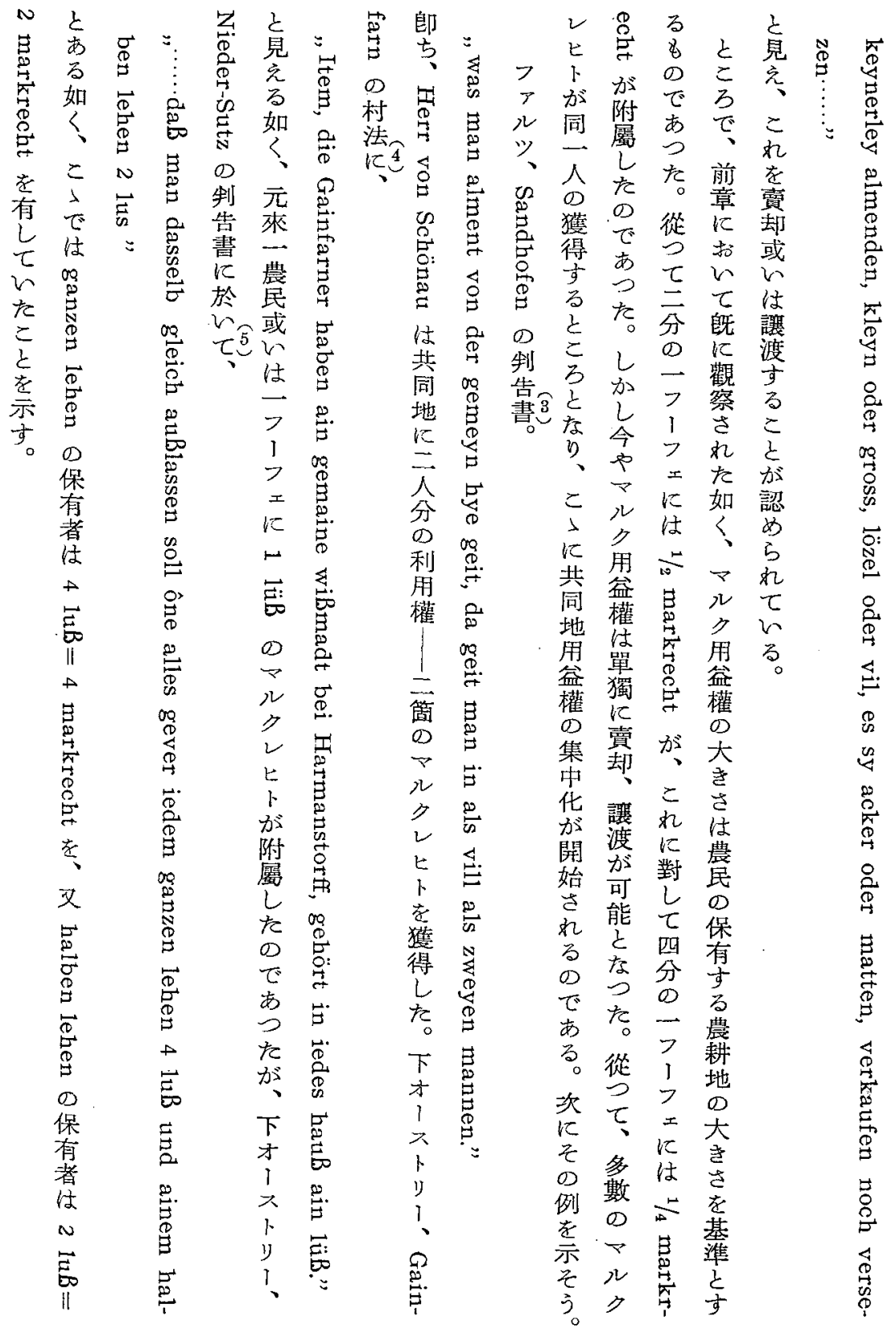




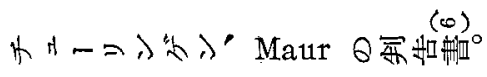

„, ad curiam in Monre pertinent silve holzmarken IX, quorum nomina et situs sunt isti. Primum nemus vocatur Murelo situm in superiori parte ville, quasi immediate ad villam, quod post acto annos resectum solvit preposito xx libras. Secundum vocatur Hergebodenholtze situm retro Sumeberg etc."

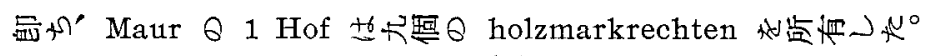

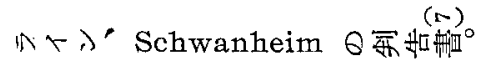

„, Da wiseten die scheffen, daz zwo und vierzig were da sin, der mit namen IIj zugehoren geinSw einheim und zum Goltstein, und auch besaget und beweret wart, daz der XV tehalbe were gehorten zum Goltstein und Vjtehalbe were dem Vrberger gude, und ein were Clas Schrymphen von Sweinheim. So gehorten die andern XXj were den von Nyderrade und zum gudenluden; das wart auch besagit und bewerit, daz der den gudenluden zugehorte dry were, mynner eins virteils, und der meister meynte doch, iss were vor mynner eyns sechstenteils gewest, dan dry were."

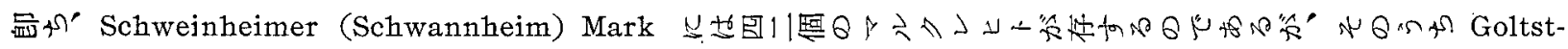

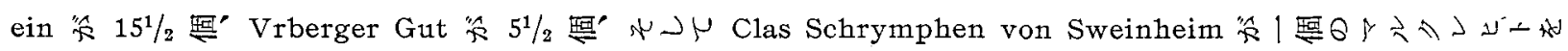

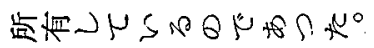

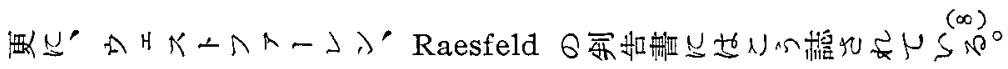

"Item de hof to Meyerink drift XXXswine, darto so vele hiie up dem troge up fuit.

Item die probstinkhof drift XXV swine, darto wes hie up den troegen fueden kan. 
Item dat holthuis drift XVI schar und negen laet.

Item die Nettelhof driftf XXIV schar XVIII laet

Item dat Wimkelken drift acht schar 1 . IIIIj 1aet. item Ruiter VIII schaer IV laet.

Item ein koever drift ein schar, was hie mehr drift, moet hie dem huis $\mathrm{R}$. betaelen, darna dat ackeren gut gewest is.

Item dat huis $R$. heft die erbgerechtikeit, dat wanner got ein gut ackern verlehnt, mit den huitluideu tuin opbreckon mag aver die erve, die den huis to R. holtbroeke geven, wo boven gemelt is; idoch plecht men gemeinlich die huisluiden darvan laeten bescheiden, darnae dat akeren guit ist gewest, inholt der berueboken.

Item wanner ein buitenman ongeorloft mit einen wagen behert in de marke, so vake as dat rat umme gelt, heft hie gebruken vif mark, und also menige span ein buiten (man) hauwet in der mark, heft hie auk vif mark gebrokte; jedoch recht sunder gnaden ist unrecht.

Item ein holtrichter heft 1 schar von den berneschote to marke und 1 schar von seinem ampte, dergl. hebben ob die scharmeisters und loepforsters 1 schar van oeren ampt.

Item die vriburger hebben 1 schar op er burgerrecht, und noch 1 schar, davoer schuldig sin er gewer to hebben in dem huise und dienst tdoen wie von alt gewonlich is."

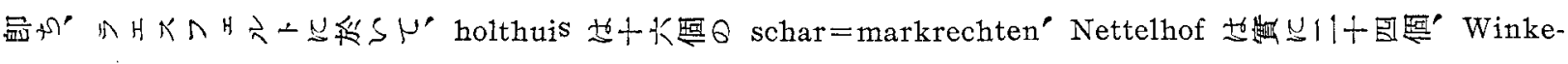

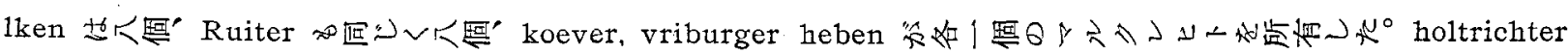




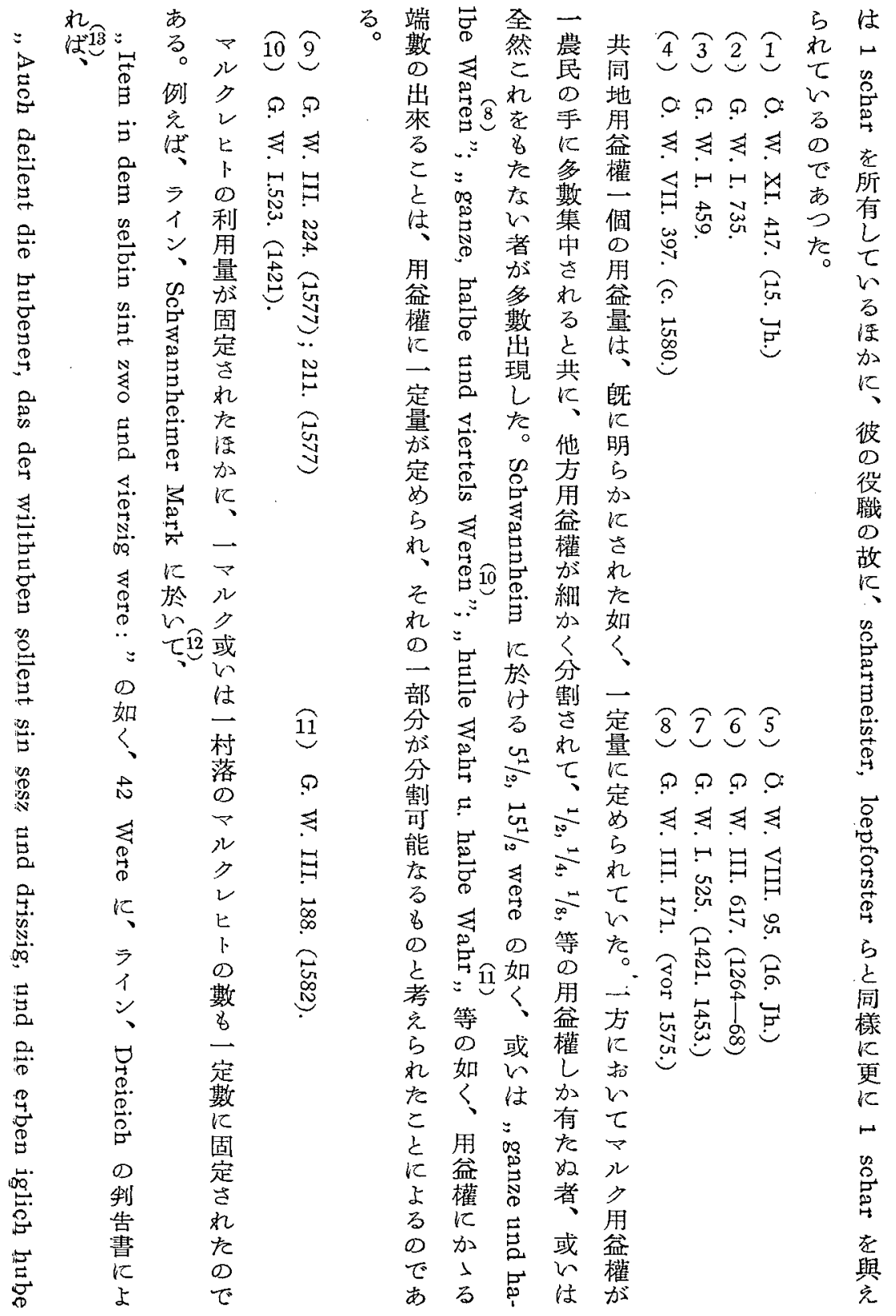


nit hoer sullent deilen, dan in vier, und benodigit sye das, so das sye die verkeuffen müsten, …."

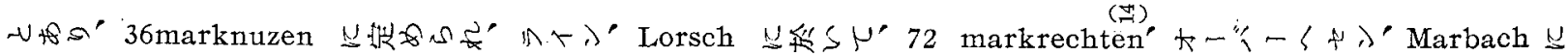

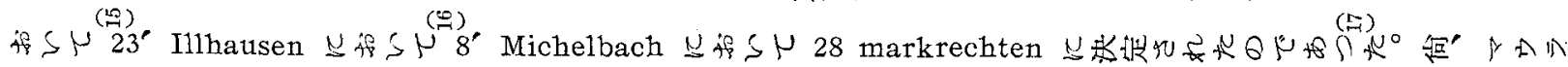

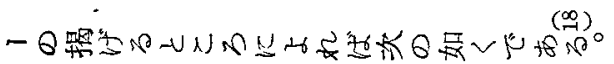

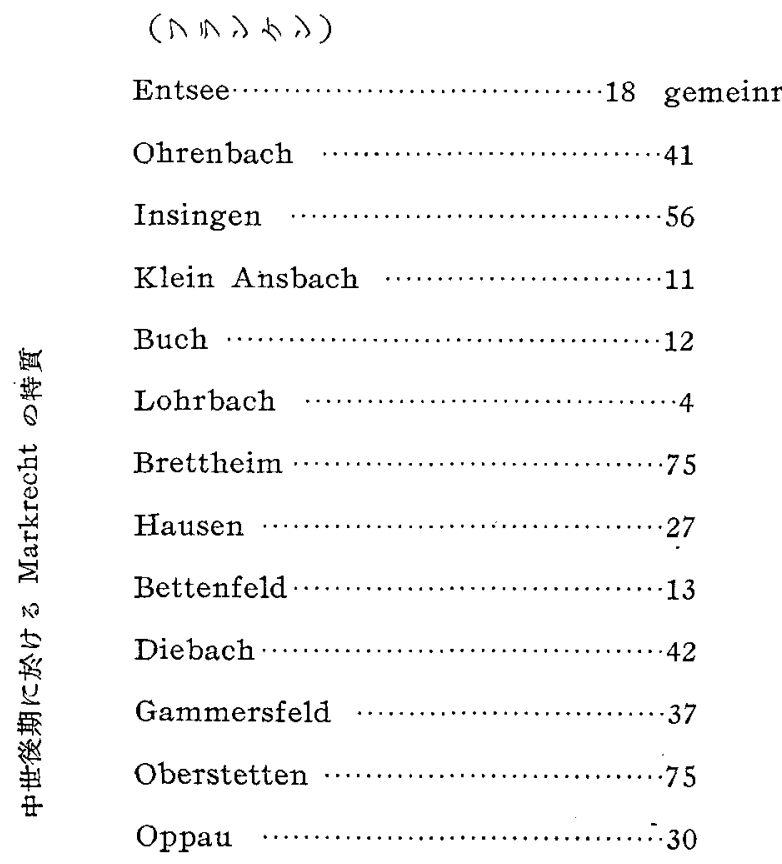

\begin{tabular}{|c|c|}
\hline & 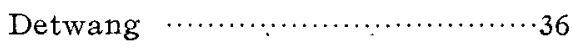 \\
\hline echten & Hemmendorf $\ldots \ldots \ldots \ldots \ldots \ldots \ldots \ldots$ \\
\hline$\$$ & 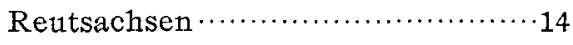 \\
\hline$\leqslant$ & Finsterlohe $\ldots \ldots \ldots \ldots \ldots \ldots \ldots \ldots \ldots \ldots \ldots \ldots \ldots \ldots$ \\
\hline$\leqslant$ & 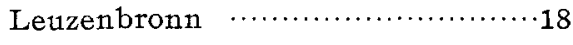 \\
\hline$\leqslant$ & 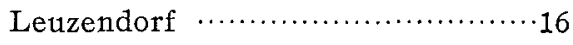 \\
\hline$\Sigma$ & 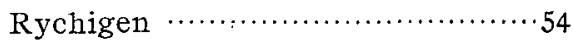 \\
\hline$\approx$ & $\left(K+K^{\prime}\right.$ Kanton Solothwin) \\
\hline 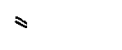 & 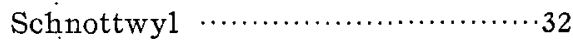 \\
\hline 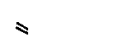 & $(N \times \perp K \cap H \geqslant-)$ \\
\hline$\approx$ & Dingelstädt $\ldots \ldots \ldots \ldots \ldots \ldots \ldots \ldots \ldots \ldots \ldots \ldots \ldots \ldots \ldots$ \\
\hline$=$ & $($ (h $r-H \gtrsim \lambda H)$ \\
\hline$\approx$ & 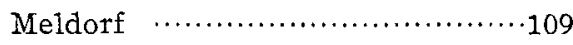 \\
\hline
\end{tabular}

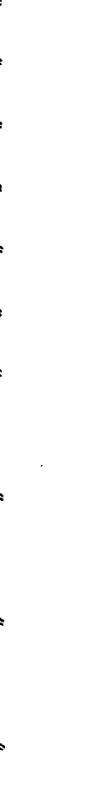




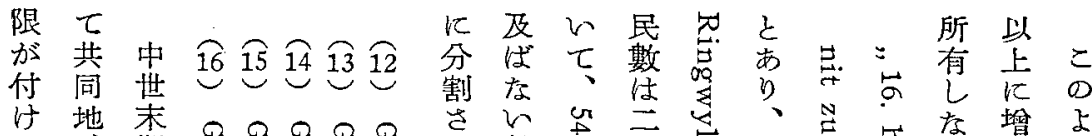

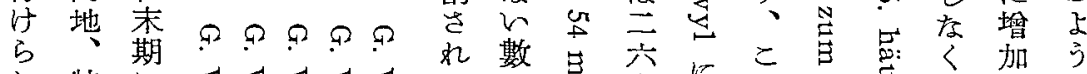

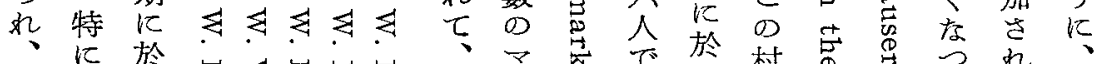

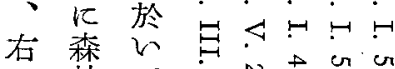

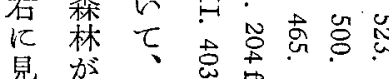
如減手省点点点

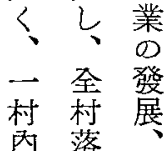

○共 鐄

$\checkmark$ 同山

ル體 業

方 員

レ D 勃

七 需 與

の

数 充 口

が足の

固 が 增

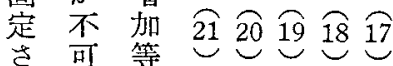
如能に

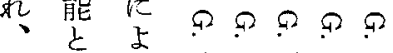

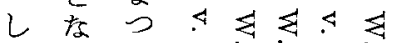

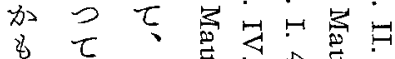

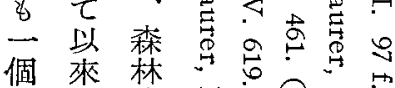

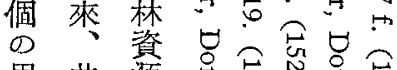

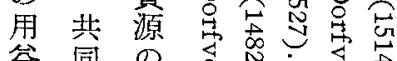
益 同 $D$ 过

權 地 需

用谷篮

益 權 急 品

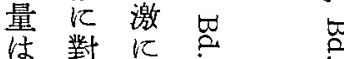

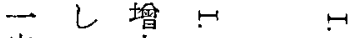

定 $\tau$ 大

種 ᄂ

の $の$ 從

飞制 己

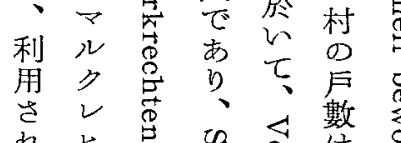

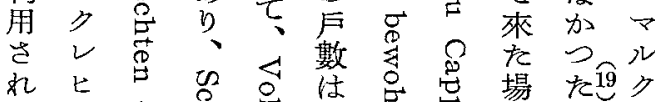

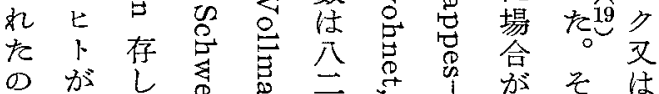

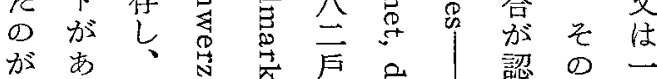

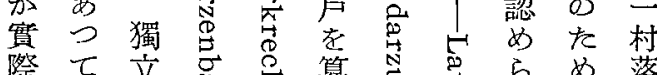

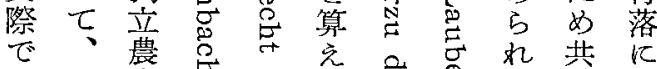

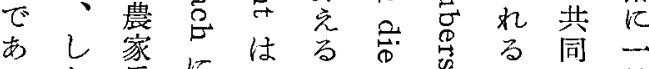

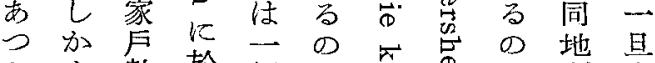
た多數於個で氮兽で利定

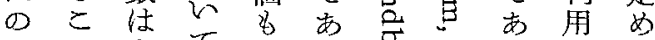

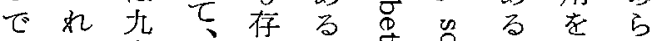
あら十在が居。必的 る 用で

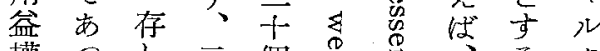

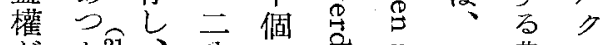

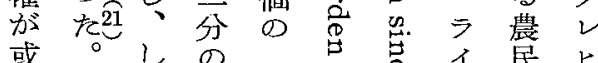
或。しの十是人民上

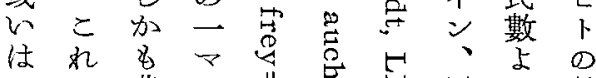
一 万農ル

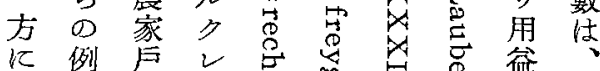

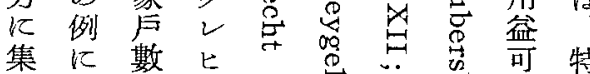

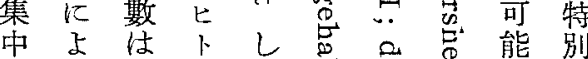

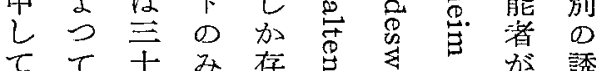

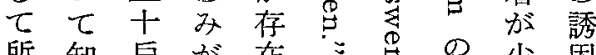
所知戶が在:怘の少因 有らで二せ 兽制く放 さ狆あ四ず、告な存

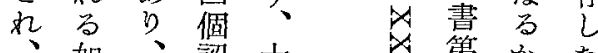

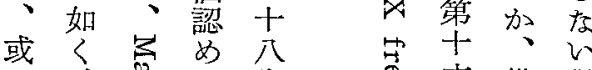

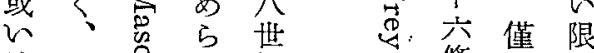

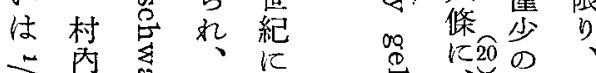

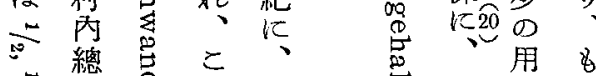
ث農总分 上层导村人權や

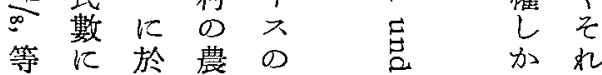


中世筏期に於ける Markrecht の特算

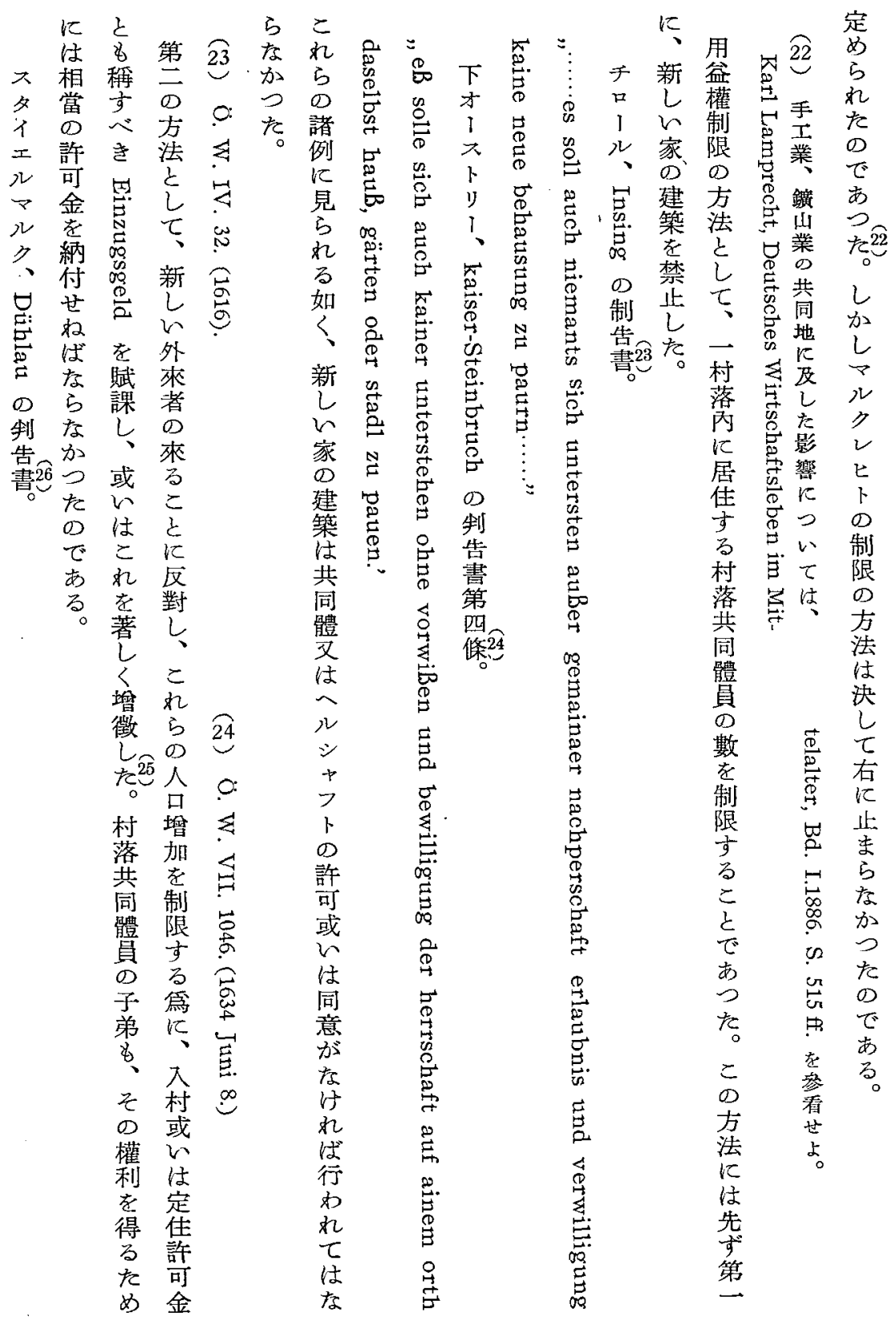




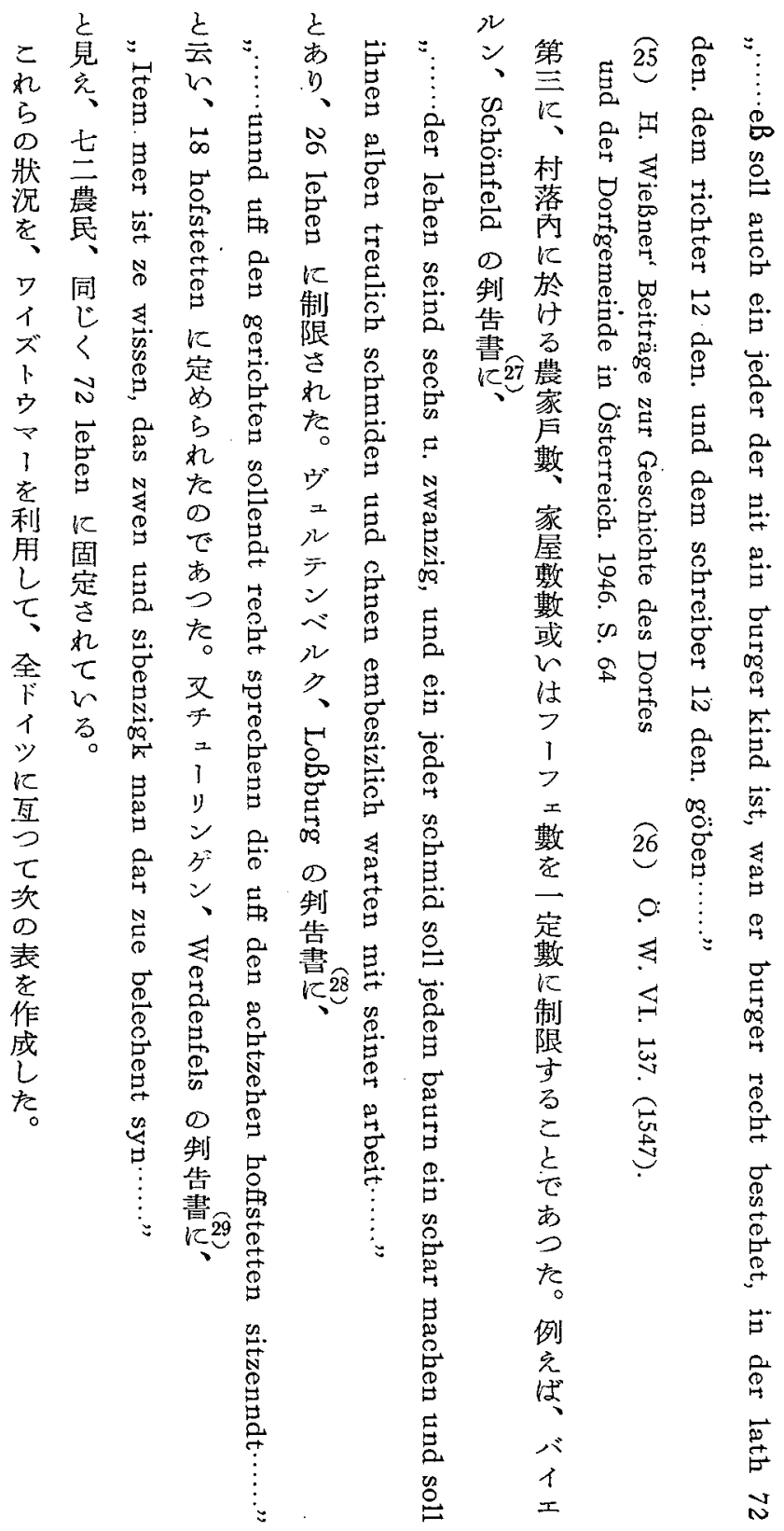




\begin{tabular}{|c|c|c|c|c|c|}
\hline 番虩 & 地方 (州) 名 & 村 落 & Hufe 又は Hofstatt 數 & 年代 & 卷 \\
\hline 1 & Thurgau & Mü1heim & $\begin{array}{l}5 \text { huben } \\
14 \text { schupposen }\end{array}$ & 1475 & G. W. I. 216 \\
\hline 2 & Schwarzwald & LoBburg & 18 hofstetten & 1477 & G. W. I . 390 \\
\hline 3 & . " & U1m bei Lichtenau & 32 hueben & 16.Jh. & G. W. I. 429 \\
\hline 4 & Rhein & Lorsch & 74 huben & 1423 & G. W. I. 465 \\
\hline 5 & " & Birgel & 19 hube & 1419 & G. W. I. 516 \\
\hline 6 & " & Werlau & 20 hube & 1394 & G. W. I . 586 \\
\hline 7 & Elsass & Artoltzheim & 20 huben & 1320 & G. W. I. 698 \\
\hline 8 & " & Ekboltzheim & 9 huoben & 1532 & G. W. I. 721 \\
\hline 9 & $"$ & Dankrotsheim & 30 hubern & $\longrightarrow$ & G. W. I. 737 \\
\hline 10 & Hundsrück & Auen & 12 hofstett & 1488 & G. W. II. 150 \\
\hline 11 & " & Kieselbach & 36 lehen & 1549 & G. W. II. 196 \\
\hline 12 & $"$ & Steinbach & 15 lehen & - & G. W. II. 202 \\
\hline 13 & Eifel & Steffeln & 5 ehen & 1519 & G. W. II. 586 \\
\hline 14 & Rhein & Wichterich & 14 lehen & 1413 & $\mathrm{G} \cdot \mathrm{W} \cdot$ II. 726 \\
\hline 15 & Westfalen & Eike1 & 20 hube & 1500 & G. W. II. 60 \\
\hline 16 & Hessen & Salzschlirf & 4 lehin & 1748 & G. W. III. 376 \\
\hline 17 & . " " & Neukirchen & $141 / 2$ hube & 1483 & G. W. III. 378 \\
\hline 18 & $" 1$ & Rückers & 7 hube & 1355 & G. W. III. 388 \\
\hline 19 & Wetterau & Vilbee & 21 hube & 1453 & G. W. III. 471 \\
\hline 20 & " & Marxheim & 60 huben & 1493 & G. W. HI. 495 \\
\hline 21 & Franken & Krotzenburg & 40 huben & 1415 & G. W. III. 509 \\
\hline 22 & " & Golpach u. Hossbach & 32 huben & 1380 & G. W. III. 529 \\
\hline 23 & $" 1$ & $\begin{array}{l}\text { Hassenbuch, Hofstät- } \\
\text { tenu. Halsbach }\end{array}$ & 90 güter & 1456 & G. W. III. 544 \\
\hline 24 & $"$ & Heidenfeldt & 8 lehen & 1420 & G. W: III: 563 \\
\hline
\end{tabular}




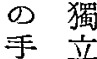

に $\frac{1}{\infty}$ 上 2827 七 右

集財 、 9 見

中物マⓆ⿻上党

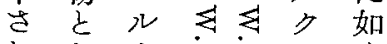

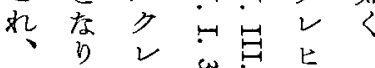

或、七 兵名新

譨卜

は耕は

僅 地曾

少加

$\infty$ 万

$\checkmark$ 離 は

儿小>

ᄀ 1

用之

谷如

權自

し 體 統

加之一。

所 ᄂ 的

有七 概

乙 賣 念

な買で

以、あ

か翋 り

全渡、

こら耕

れれ 地

を、场

所更附

有に屬

乙用 物

な谷で

认權 あ

者唯つ

分 分

出割 が

現 迄

于 的

万て

に、經

以或濟

灰出的

○は重

た特要

事 定 性

情農兮

が民ら

制 以

ᄂ 0

子 建

築

¿ D

乙 禁

t 步

で外

あ 來

万楮

防

些

或

29 は

व 1

ঊ

恕總

g్

$\stackrel{乛}{\vec{\omega}}$

農
家
E
數
0
固
定
等
種
\&
な
る
方
法
に
よ

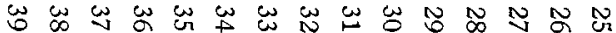

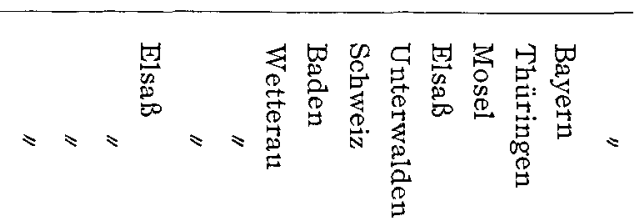

忎念的占

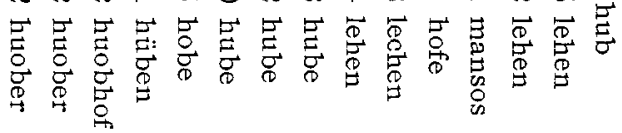

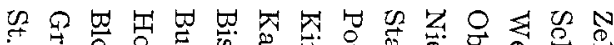

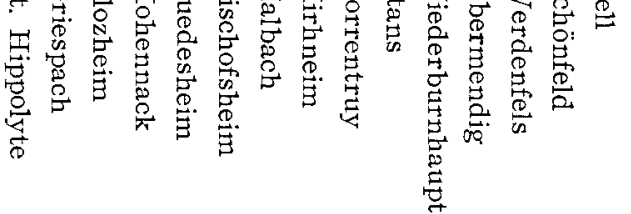

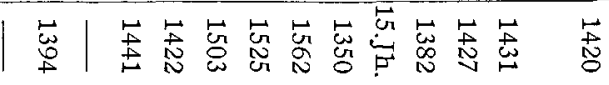

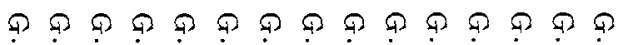

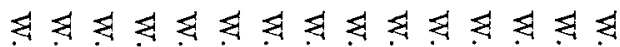

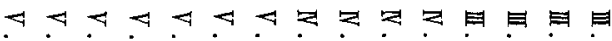

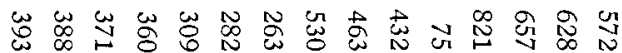




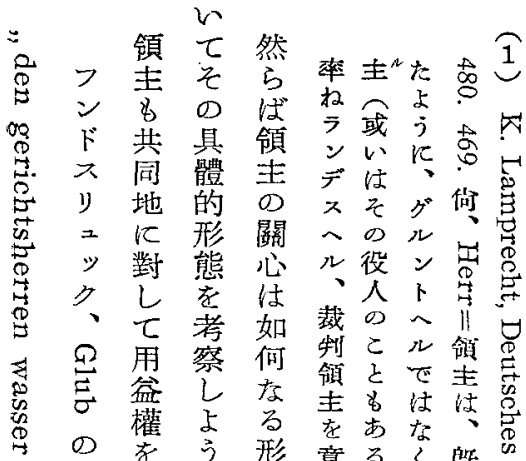
制有省方形意方く、既々

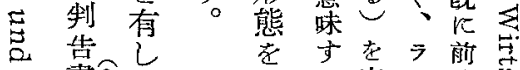

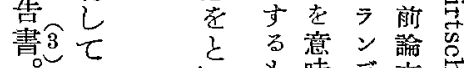

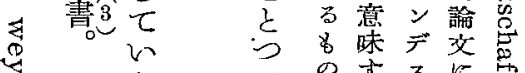

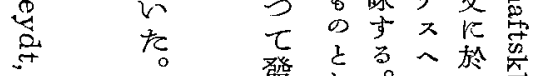

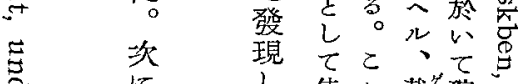

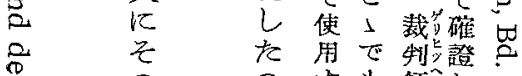

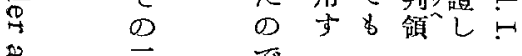

三

节 三

落 例

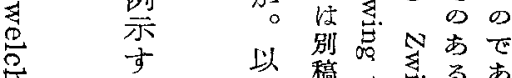

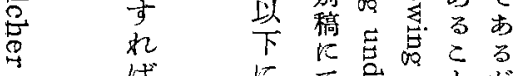

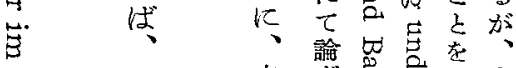

草

管.

$\stackrel{2}{0}$

染.

0
0
0
0
0
0
0
0
0
0
0

獵 份㤬 会

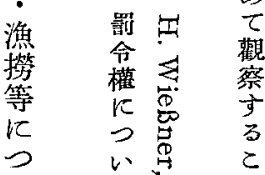

でが㩐の常 以

る。资主使第卡

にあ重重劣

罰つ大大

令て度市

權、響る、第

のそ影閣村七

成 $D$ 心落章

長他與を共

子の充抱同領

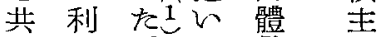

飞用。員的

共は

同餘ンでマ害

地りデあ几 の

心重スつク發

管視へた用現

理さル。谷形

にれの特權熊

店、にに

關务共中つ

與

乙地末

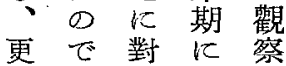

にあす打已

農るるけた

民。利るの

の然害領 で

マ过邦古

ル最、主る

句初最權 が

用違初 0 、

益 反 極發領

几。者め展主

對に $\tau$ \&

乙 對 限 共

$\tau$ 广 5 共 同

貢るれ同地

租處た地に

を熼を 特 對

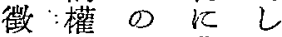

收をで農て

守有古民任

るし D D 種

化光、森々

いの狩林な

たで獵用る

るあ、谷利

のる漁權害
明

5

ic

$\vec{c}$

れ

た。 


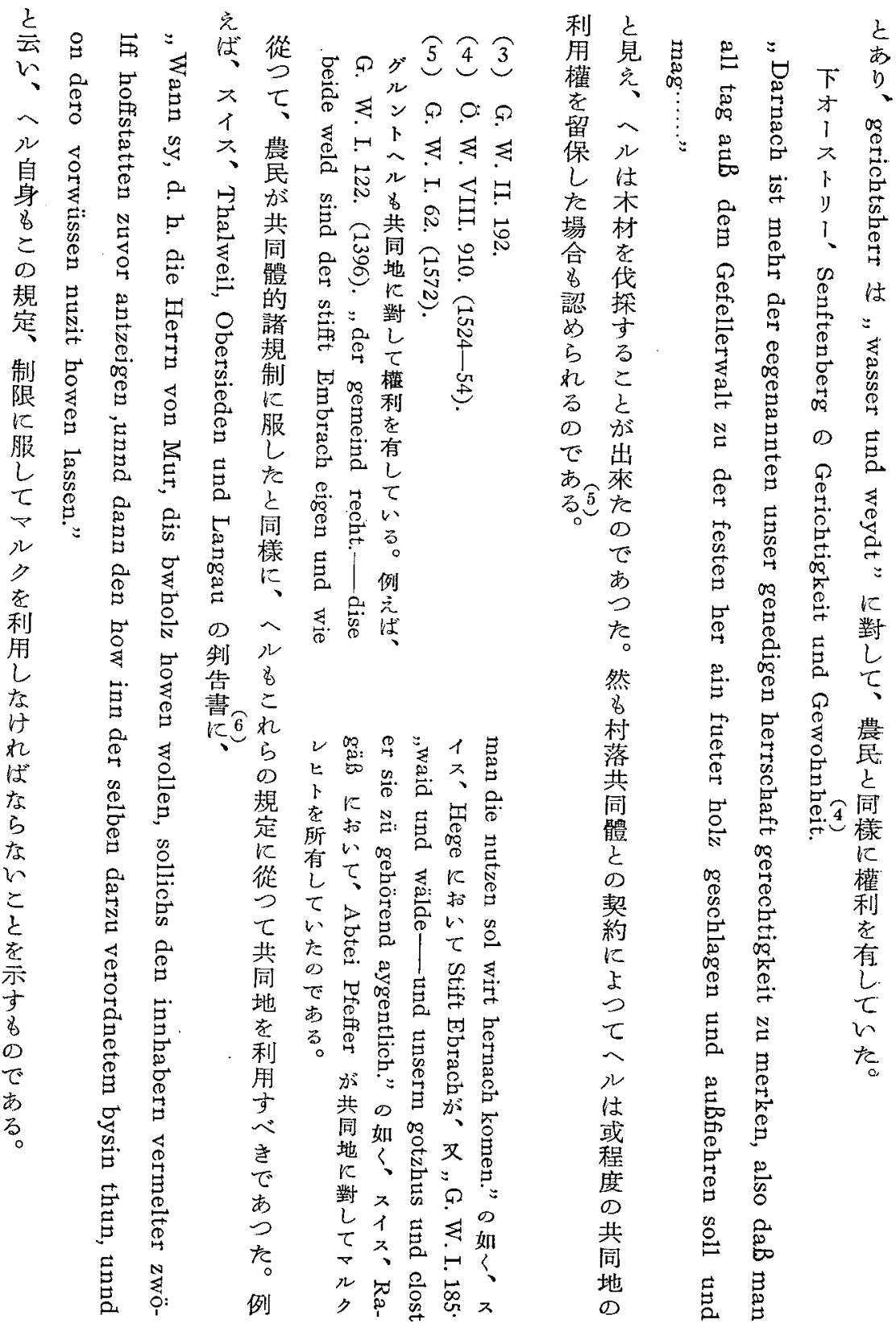


中世後期に於ける Markrecht の特質

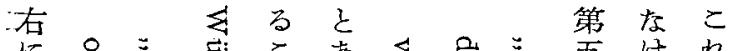

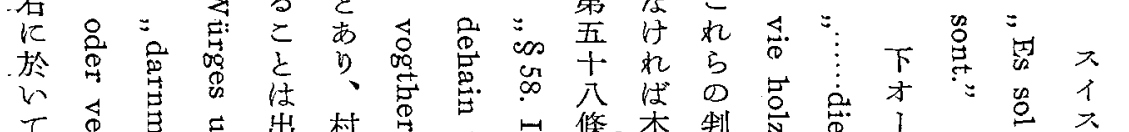

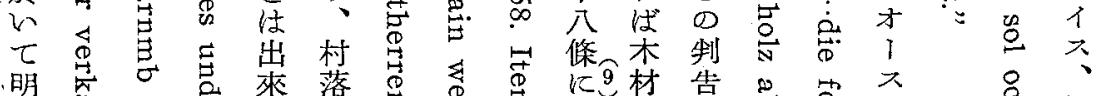

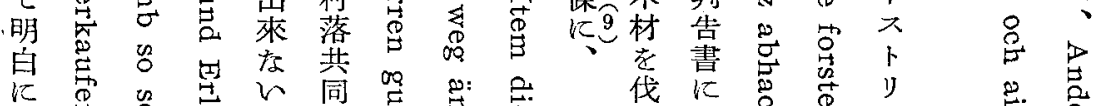

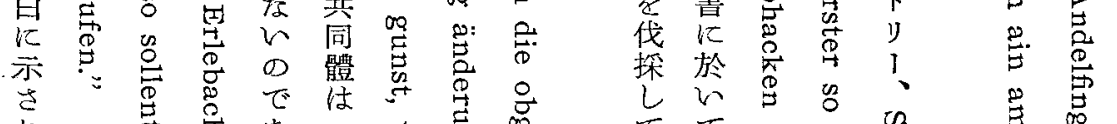

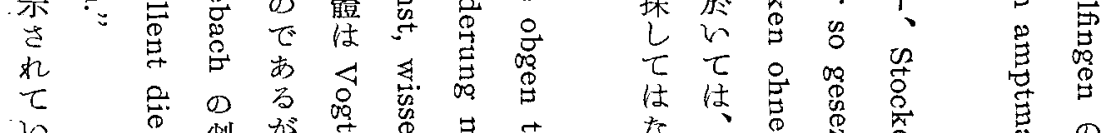

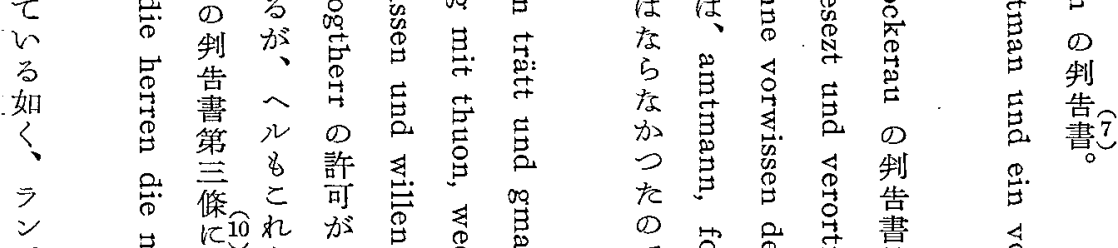

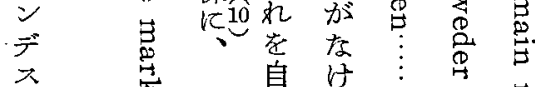

几 息

及

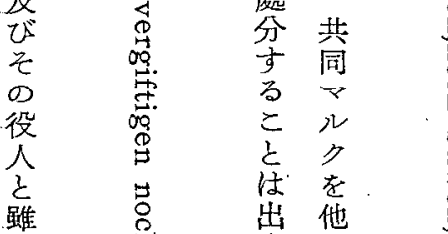

村

同體



承

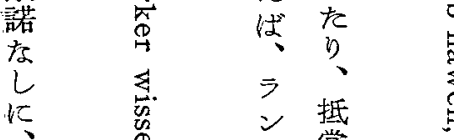

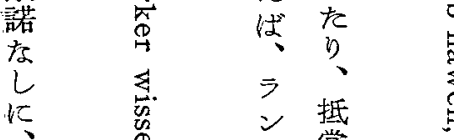

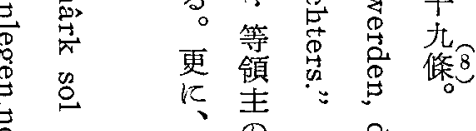

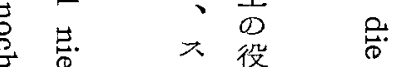

要

$\underset{0}{4}$

芯.

范

卢

大 8 帝 告

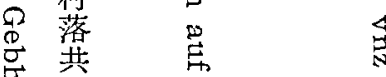

焉

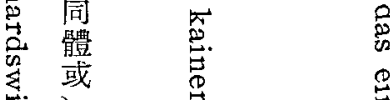

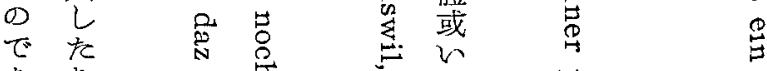

あ

る

营

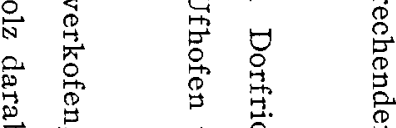

$\underset{ت}{\Xi}$

\begin{tabular}{lll}
$\overrightarrow{0}$ & $\overrightarrow{5}$ & $\stackrel{5}{5}$ \\
0 & $\stackrel{5}{0}$ \\
\hline
\end{tabular}

冠 0

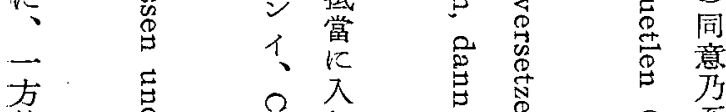

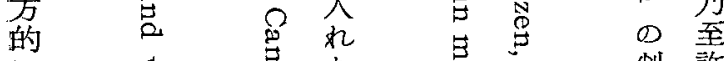

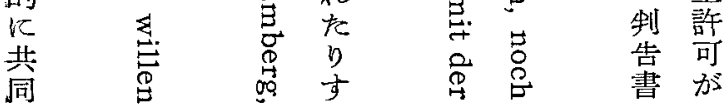




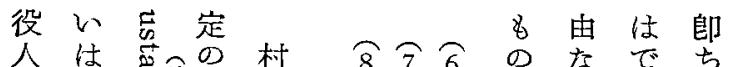

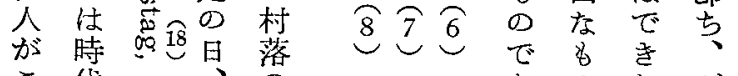

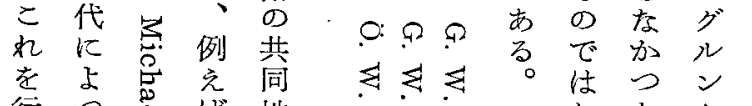

行つ导住地

方正聖利

占年

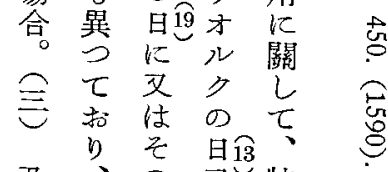

及、D爻特

びこ前はに

雨 こ後聖 そ

者に守の

が グ集 ル管

共 $\supset$ 于理

同イてンに

でン協のつ

行デ議目两以

或 L 记

場认て 或 は

合は决々村

等 $甘$ 定は洛

が等共

見密杂范: 同

出造总淿體

れ

万がし

の 貫 こ

で蔡怘常》

あ管 管總

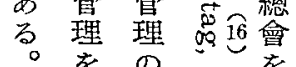

1ㅣ 10 의

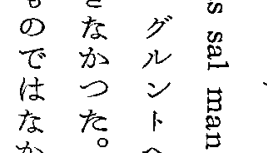

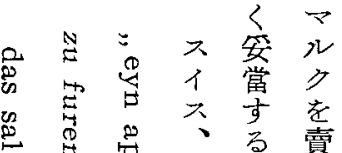

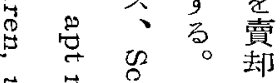

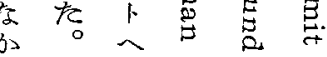

$\supset ट \mu$ 吉苛邑

た 08

で

あに

り

兩 8

者 共許

權地疗

利に

は 對に

相 ᄂ 共

互乙同

に 權 $\checkmark$

尊利ル

重をク

さ有に

就招

諸 の

Q $Q$ 規で木

定あ材

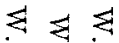

H+ 4

感讨

行實 00 開

引祭志心

場 0 i

合責芭決

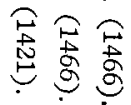

㷊壳伐

充 が 伐

服之管

從れた

就

る決、

元

き $\tau$

偪或

或

は

( 其

总总制告他

○任突定

共 加

の同 5

で 體 勝

あ 0 手

規に

$\therefore \quad$ 書11

三 村 $\overrightarrow{0} \cdot 17 れ$

落 $甘$ る

人洛思㤎

た制運

こにび

又つ官或

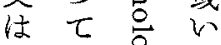

乙服 出

巳

そ学は

示ぬ

范粕方

$\varnothing$ 或

寸自之

\&

?

處

分

ᄂ

は

な

b

な

加

2

t。

以

上

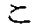

z

グ

ル

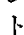

r

r

r

o

w

$\tau$

8

全 
中世後期に於ける Markrecht の特質

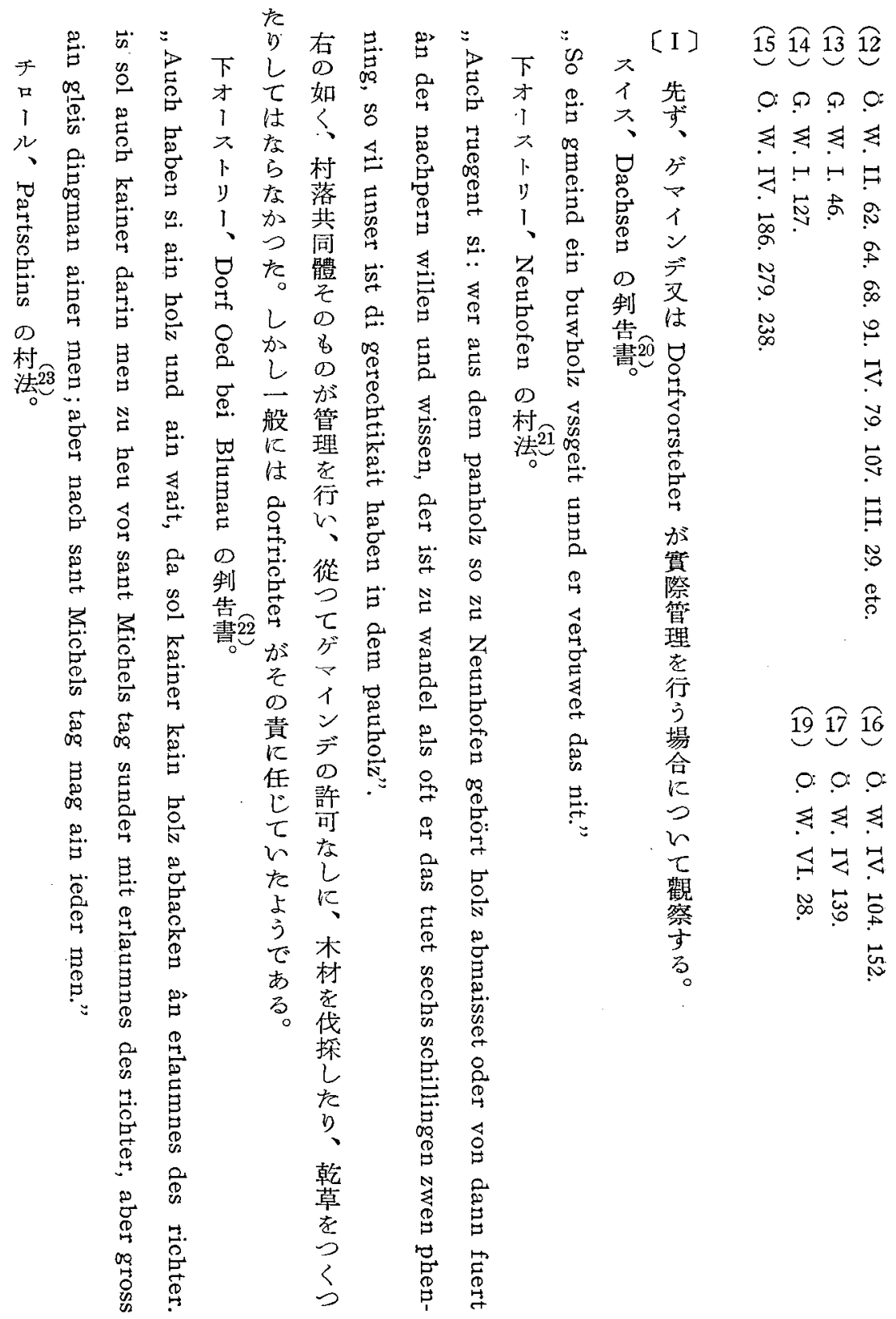




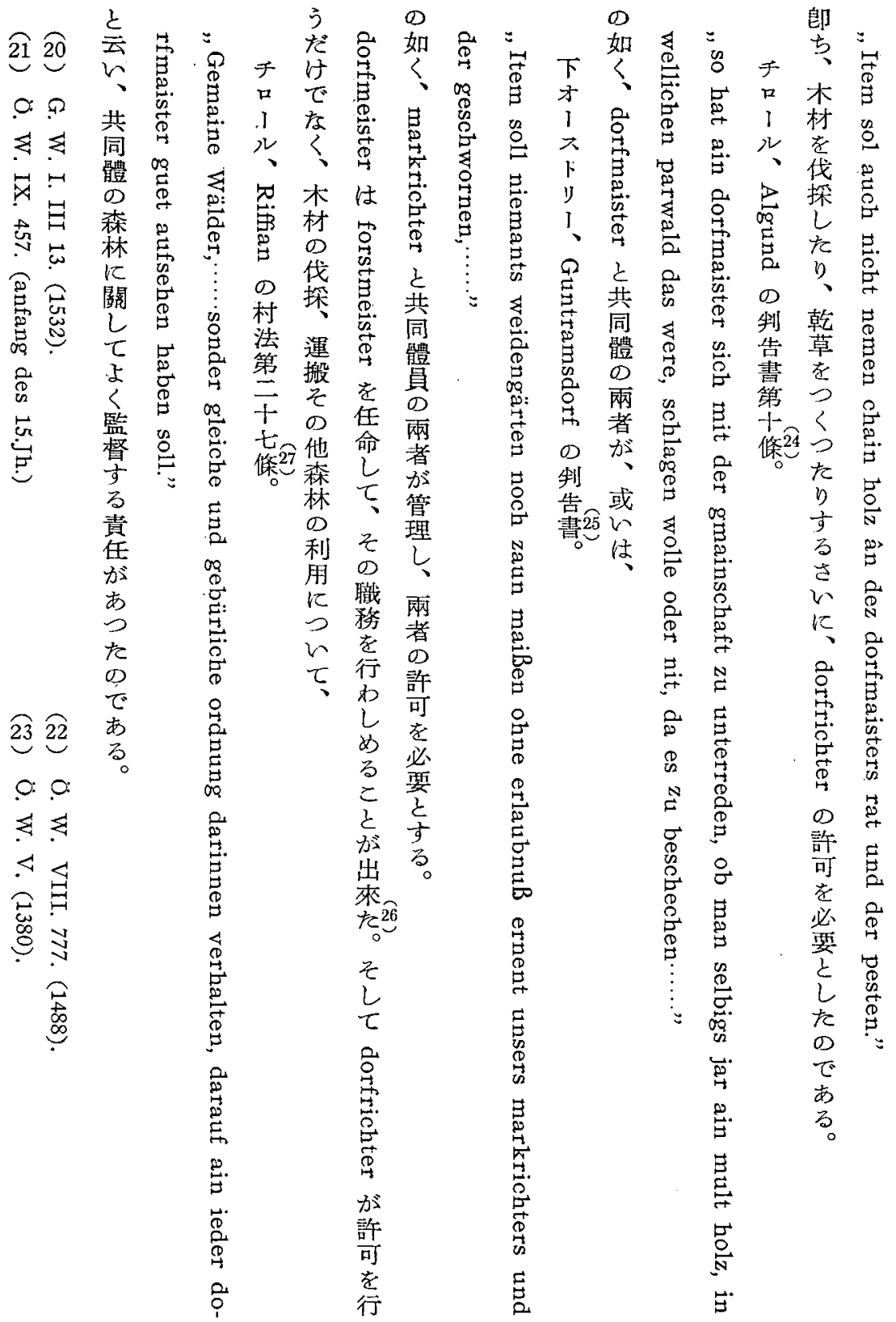


中世後期に於ける Markrecht の特質

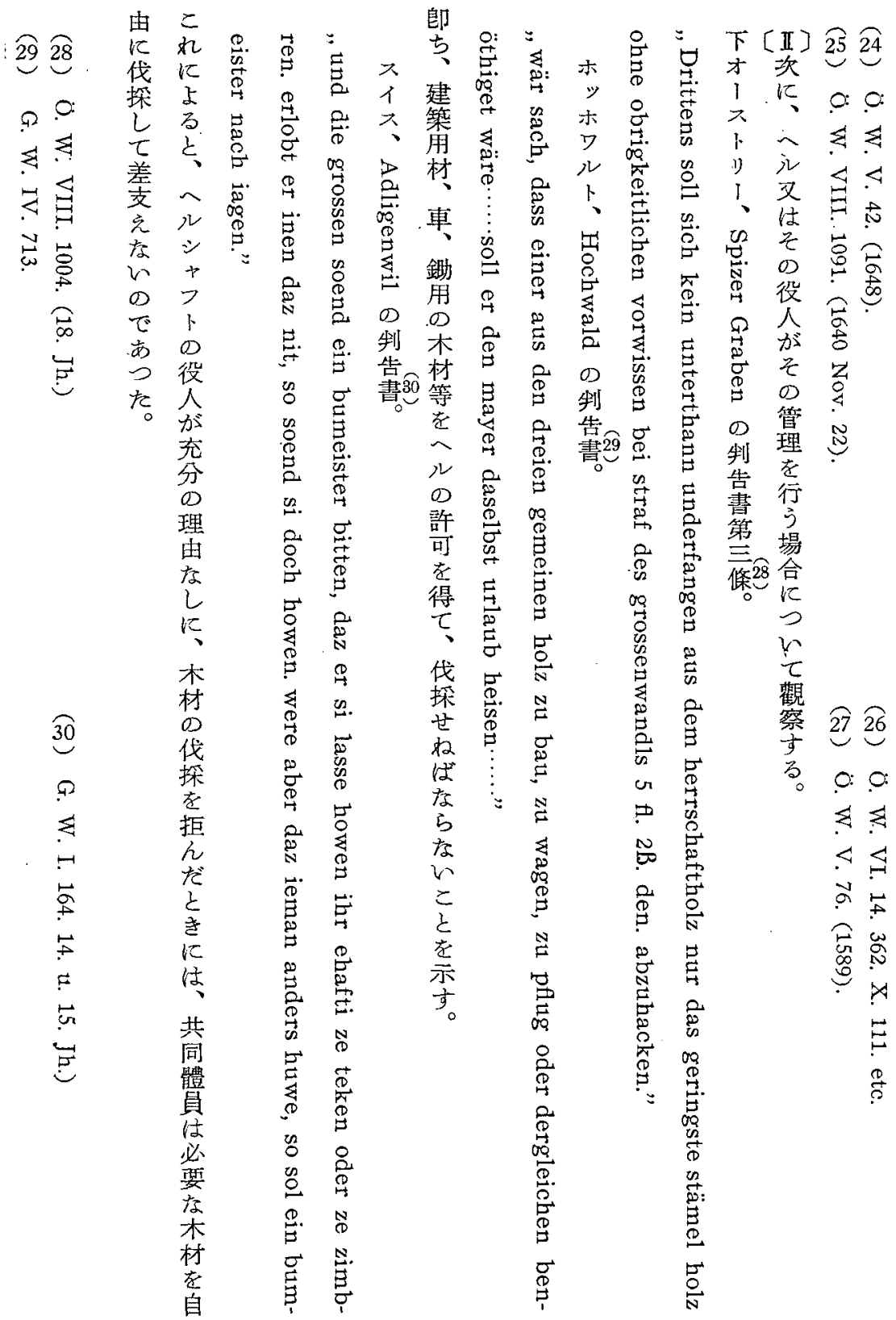




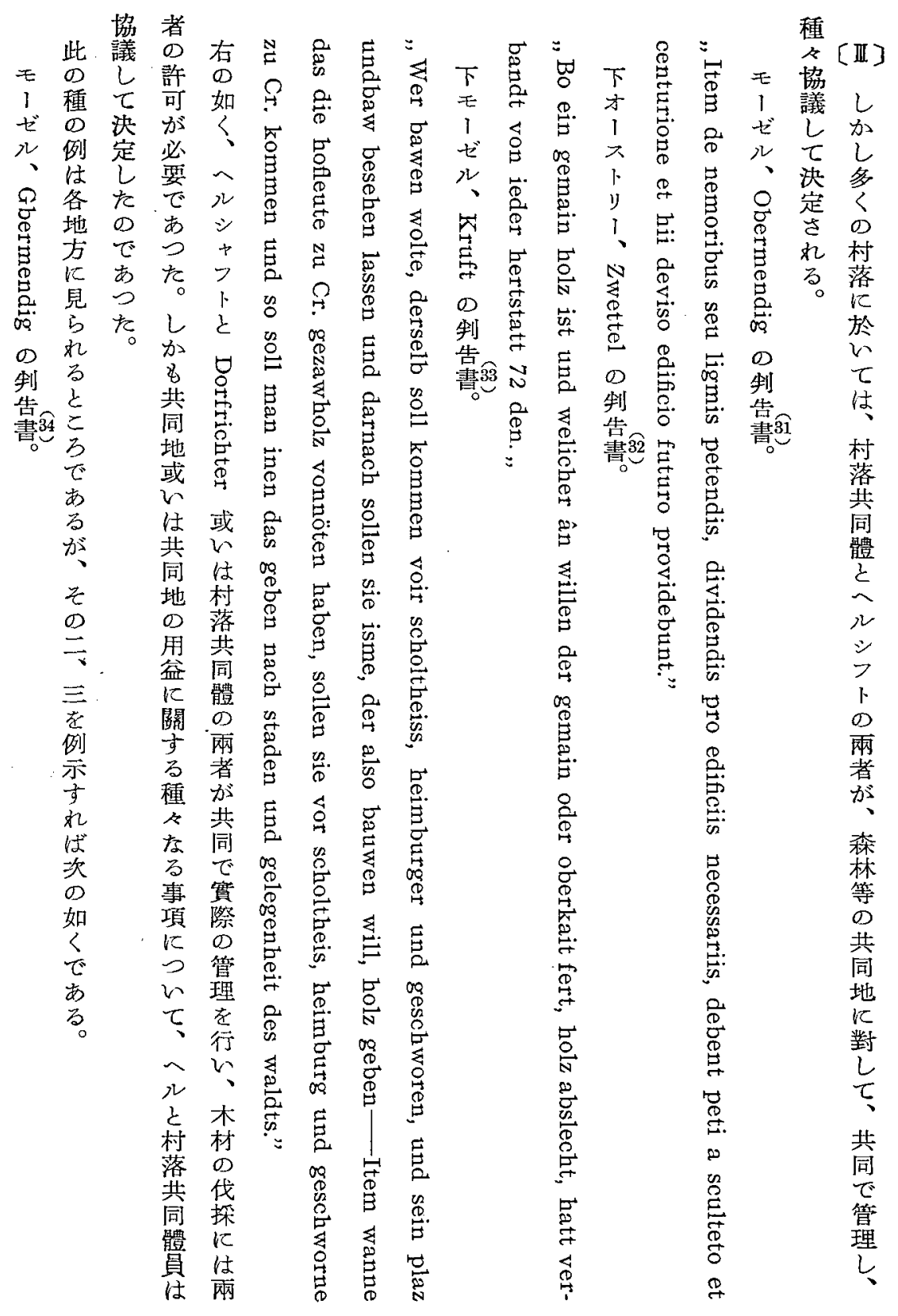


中世後期に於ける Markrecht の特質

を行 $D$

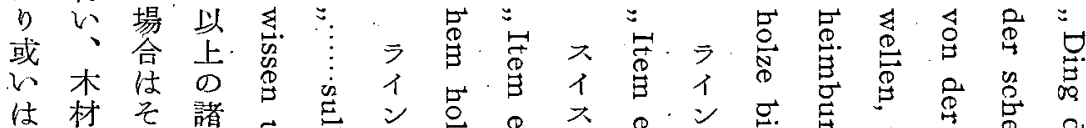

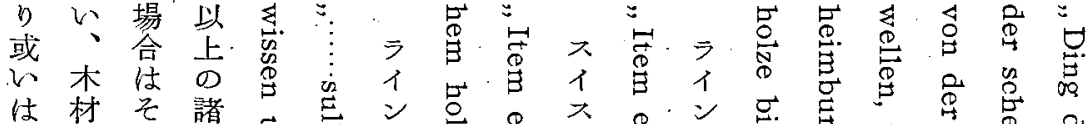

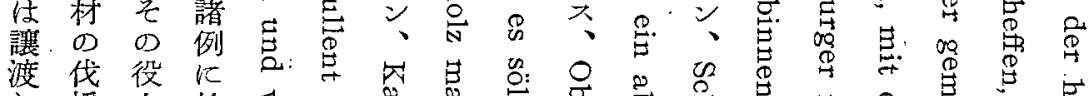

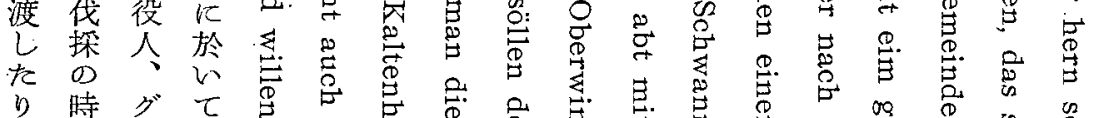

り、時 グ

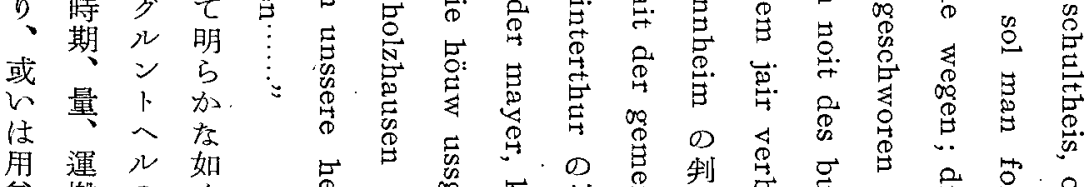

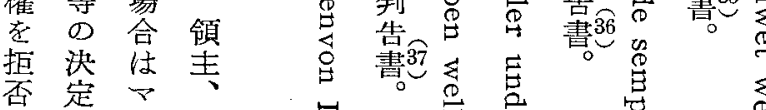

专质農

るびェ 民

そ少及

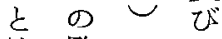

は監がグ

出督集 ル

來をつン

ななて、

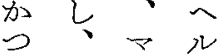

たこルは

れ夕共

ら利同

の用地

規にに

筀閣”對

老 文

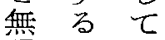

顥 種 權

しな利

七应

一る 有

方用 的

に学こ

$\checkmark$ 協

ル 議 ら

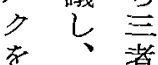

賣管

却理 領。

し 主

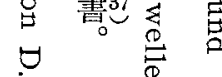

量.

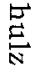



(1)

遇

屌

$\stackrel{R}{9}$

$\stackrel{B}{\stackrel{B}{2}}$

寄

$\stackrel{8}{8}$

芯:

蜜:

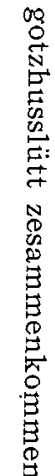

点 点

N

望

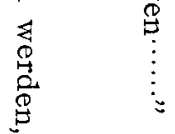

葛.

ڤ્.
点

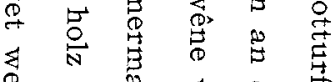

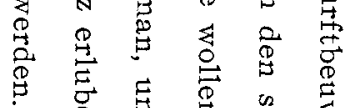

突

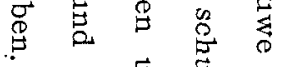

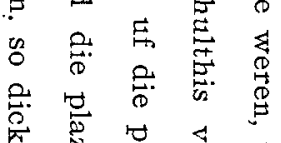

苛

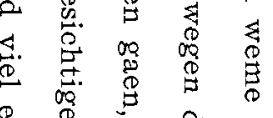

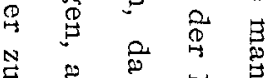

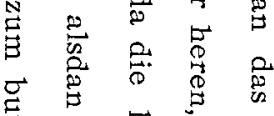

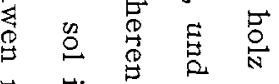

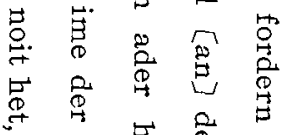

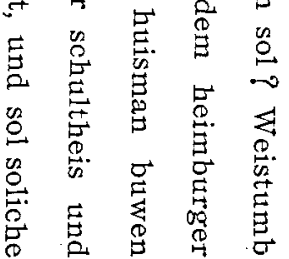




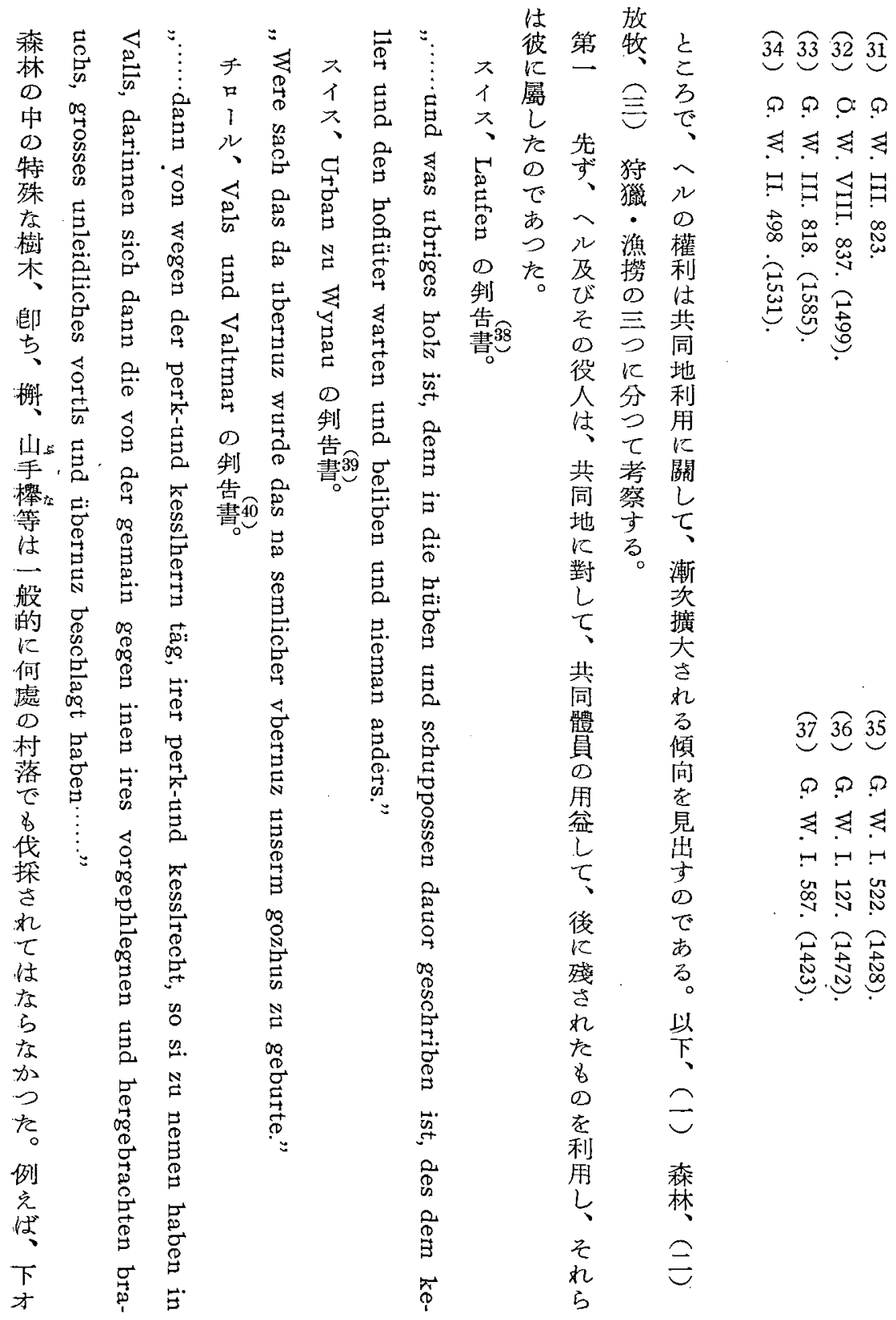


中世楼期に於りる Markrecht の特質

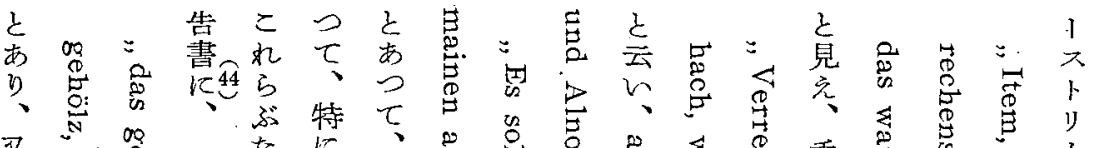

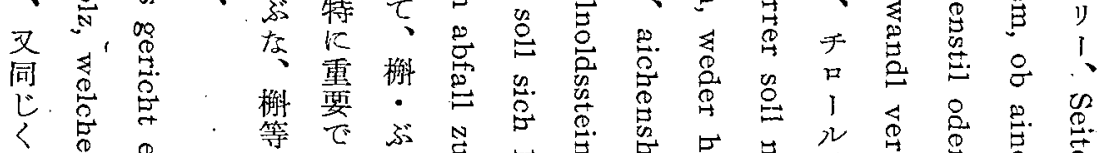

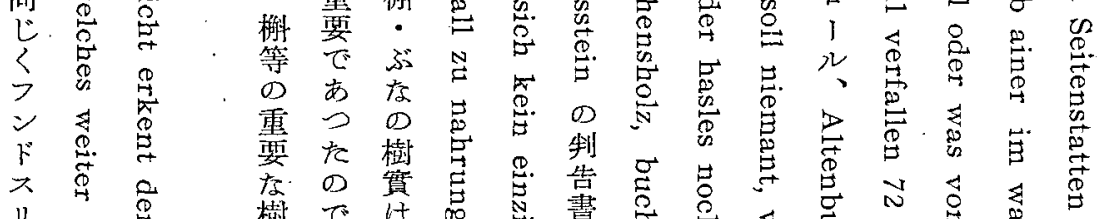

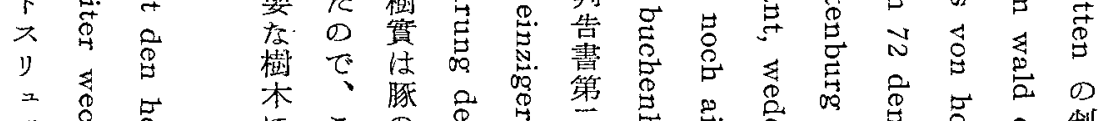

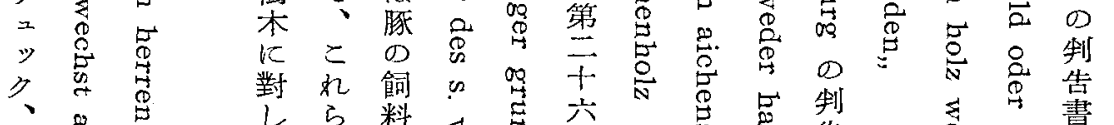

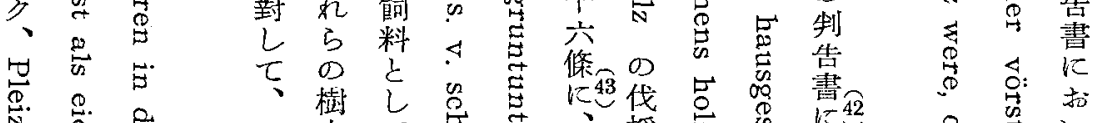

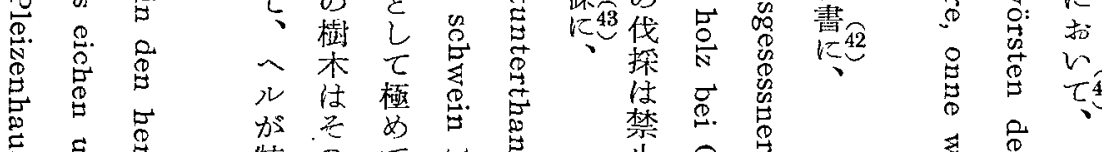

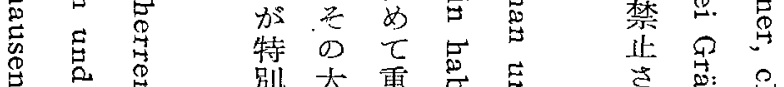

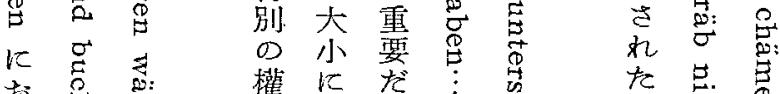

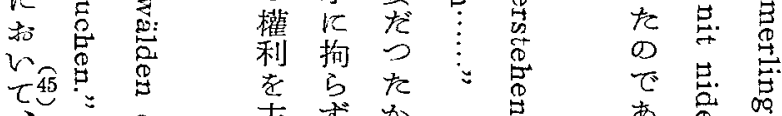

者

芯張伐 ら

を探で

吉例禁尘

方齐箖

ばれ、林

$>$ 保 於

ン゙護预

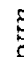

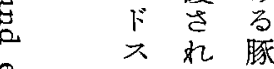

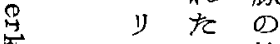

要 $=0$ 放

$\stackrel{\rightleftarrows}{*}$ で 牧

口名權

急次

呑等共

总含然骨豊

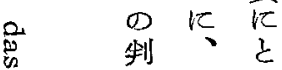

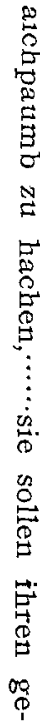

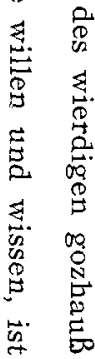

క

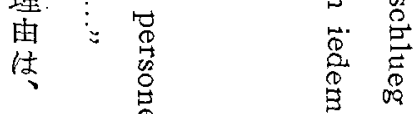

욤

点

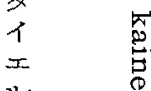

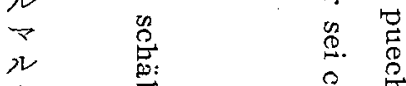

ク $\begin{array}{lll}0 & 0 & 0 \\ 0 & \stackrel{0}{0} & \stackrel{0}{9}\end{array}$

in

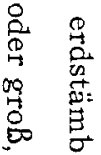




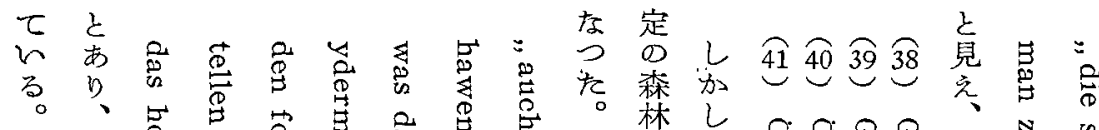

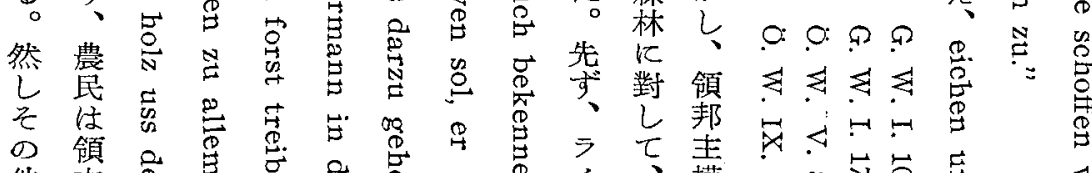

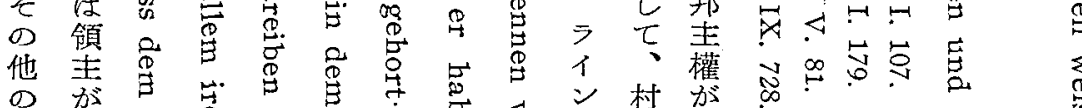

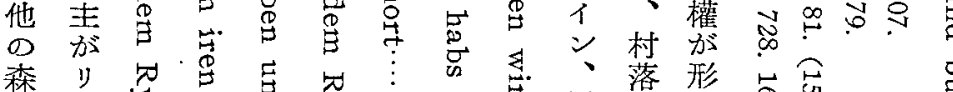

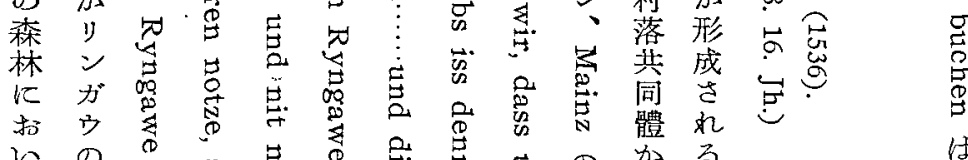

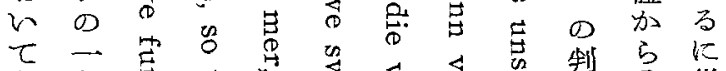

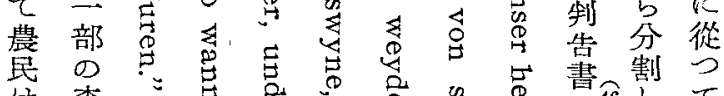

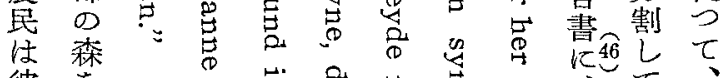
彼光 ら分 家 要 にる 必こ 要 度索 木 認 材如 伐そ 探こ ᄂ 於

森 以

林 $\tau$

の 决

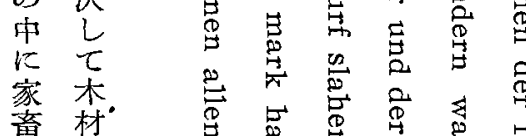

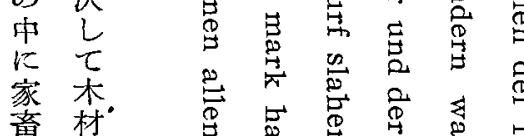

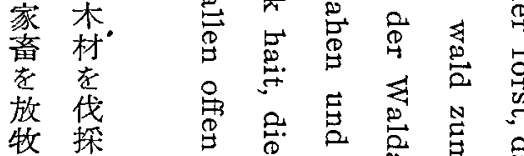
市 L 万存 $\approx w$ c 2 出光 來 鳘

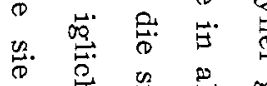
当保他

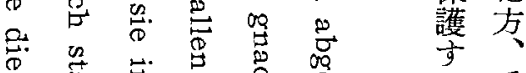

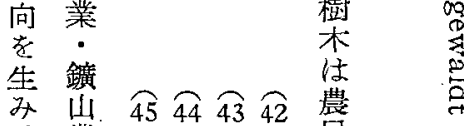

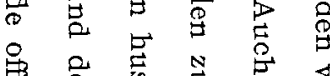

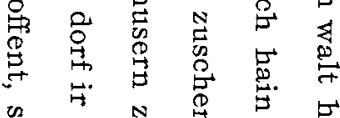

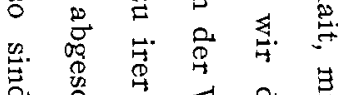

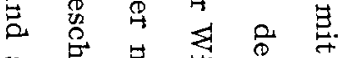

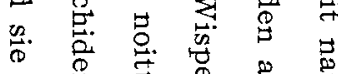

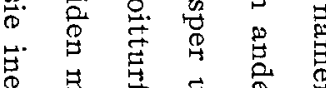
万つ

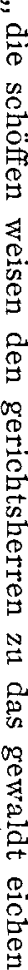
芦

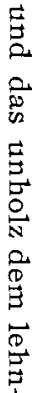


中世後期に於ける Markrecht の特質

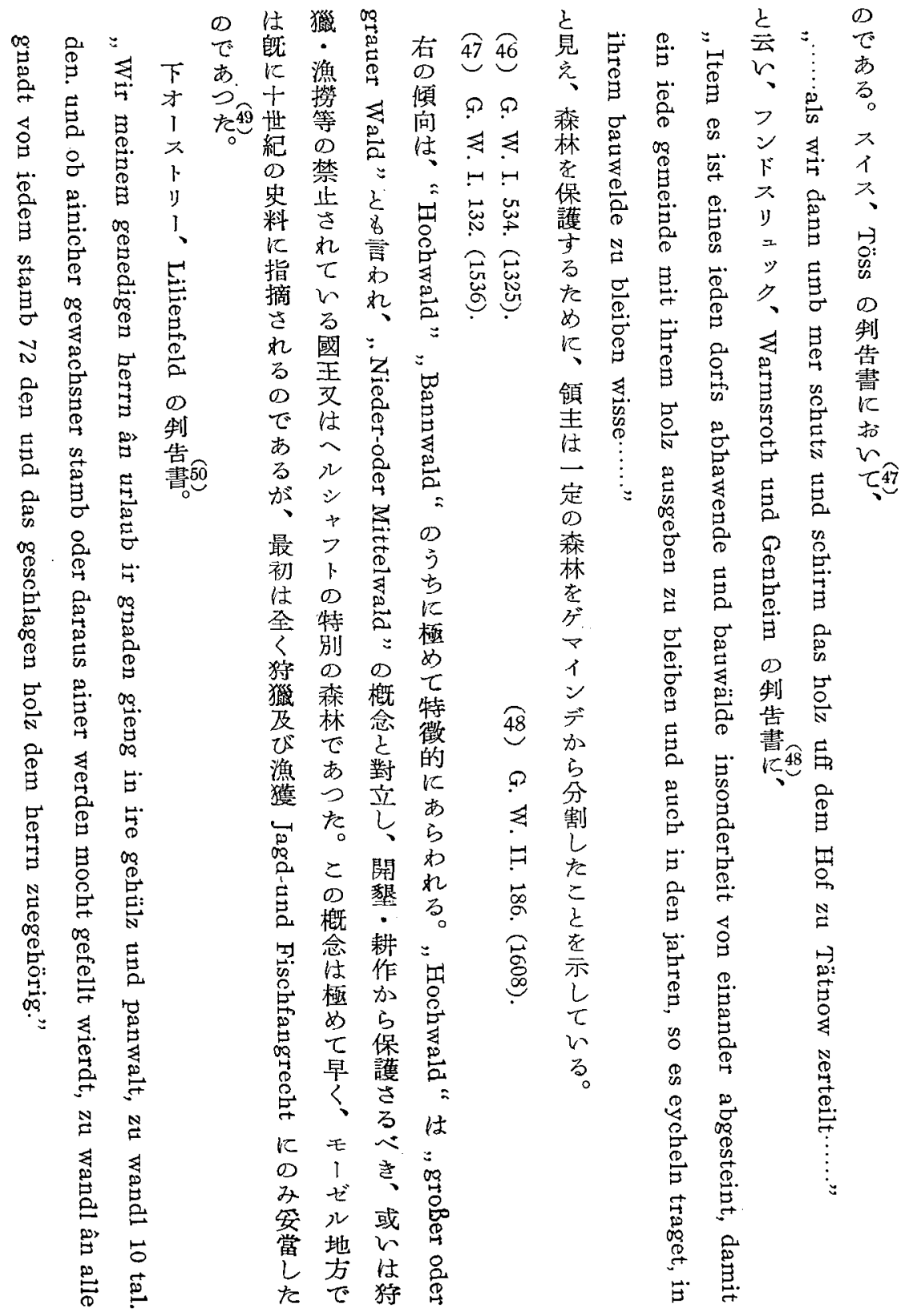




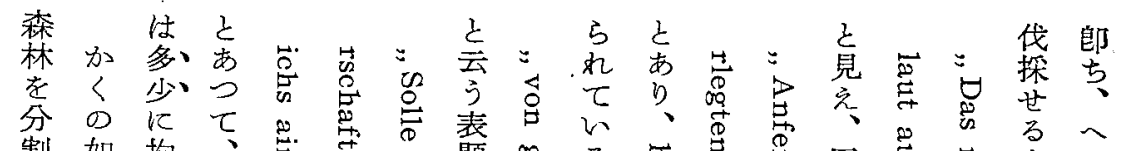

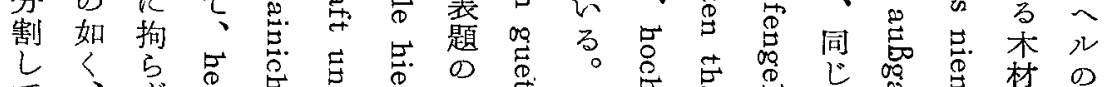

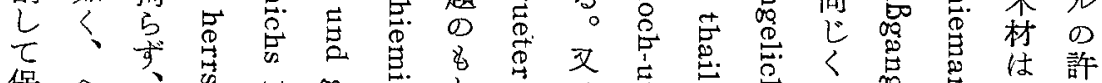

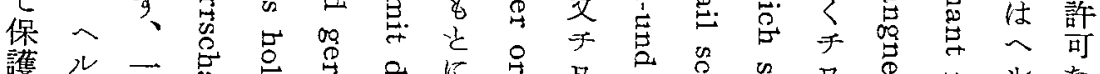

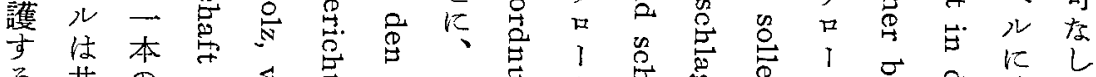

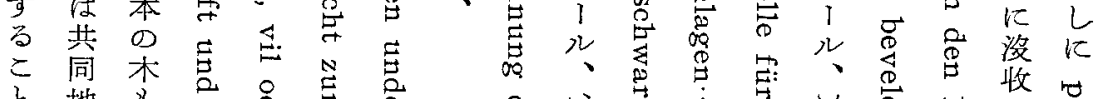

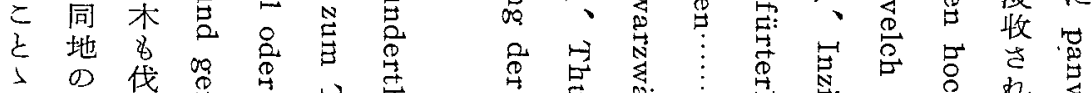

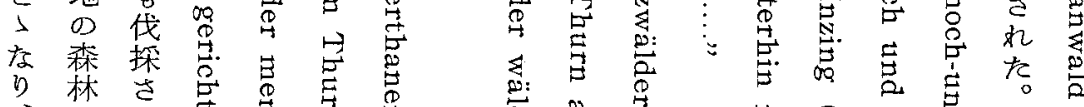

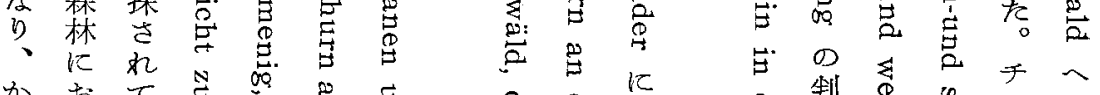

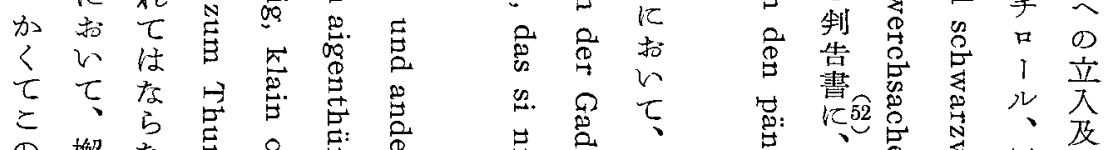

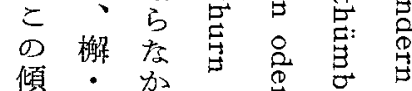

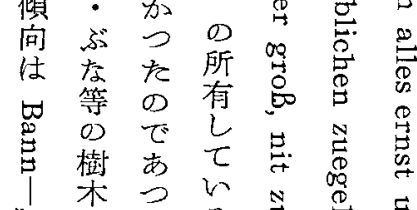

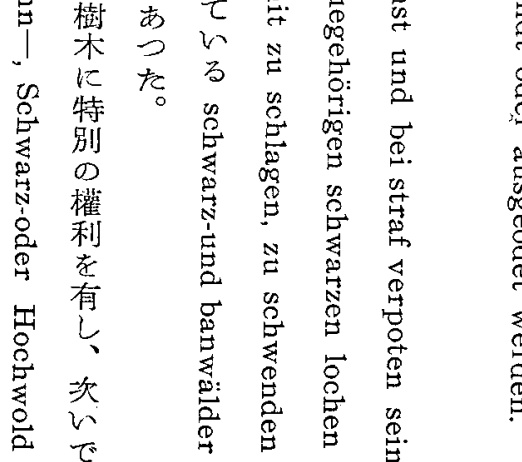

の村次吉

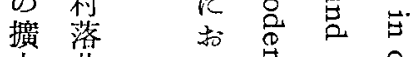

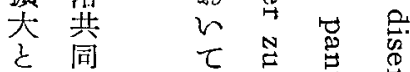

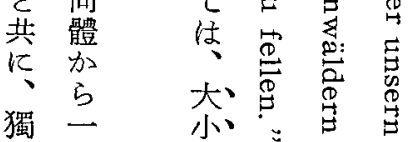

点定或导莡

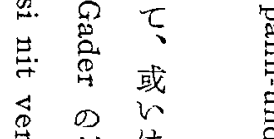

制は

告 粕:

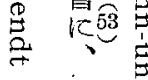

窟

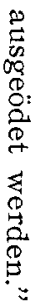

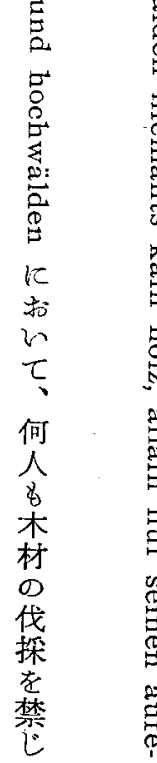

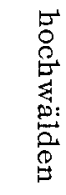

显

胥

忿

总

苛.

苛

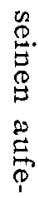

通、及

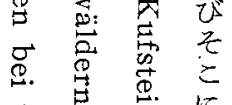

4 要 $K$

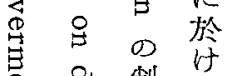

家. 制等

容落告查

䓌畫第

浛言六伐

揬

宿は

悠䉷

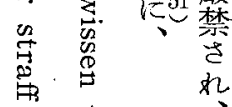

总吉芯

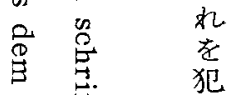

恚点芯芯

罾

怘

處

せ

b

就 
中世後期に然ける. Markrecht の特質

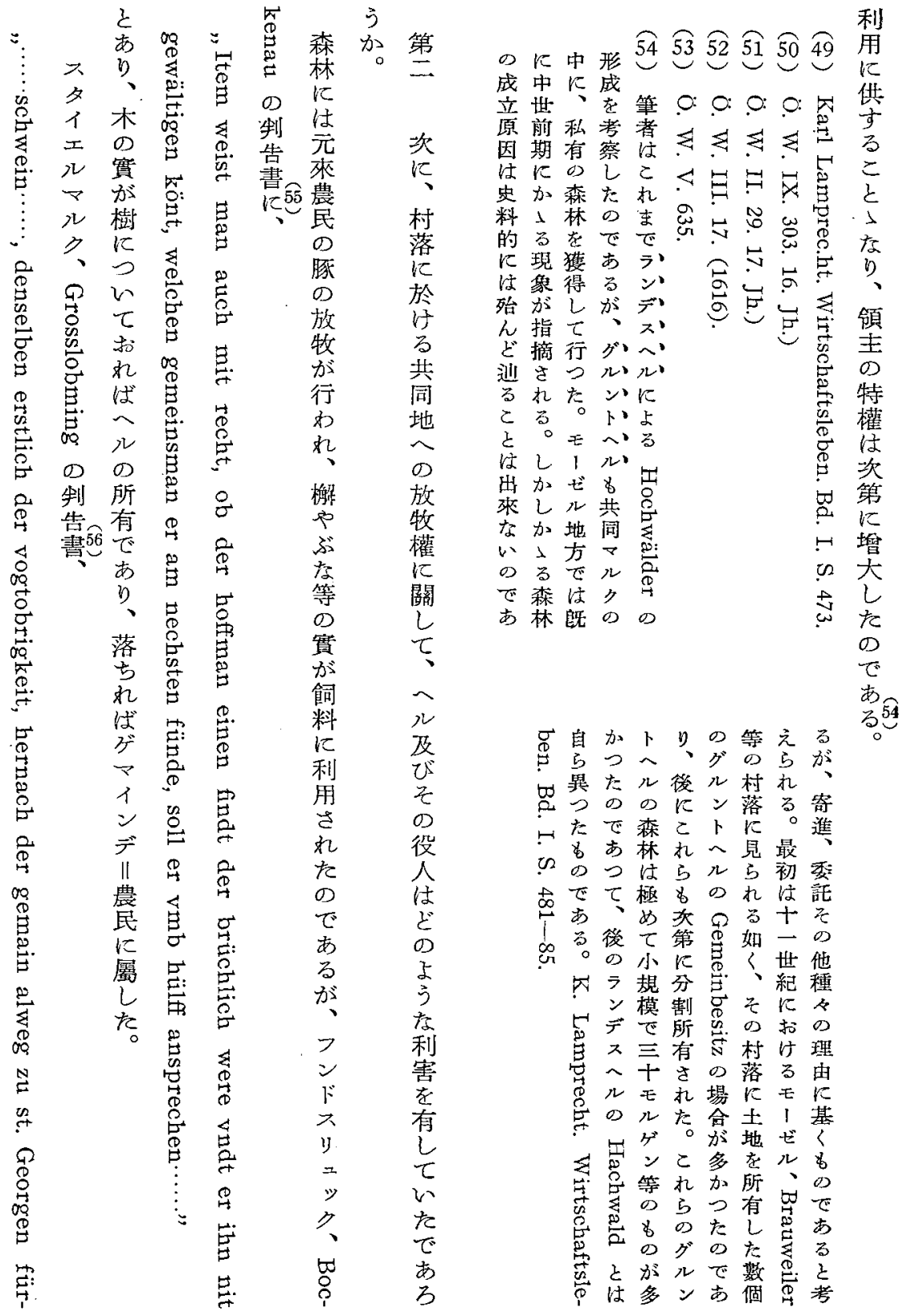




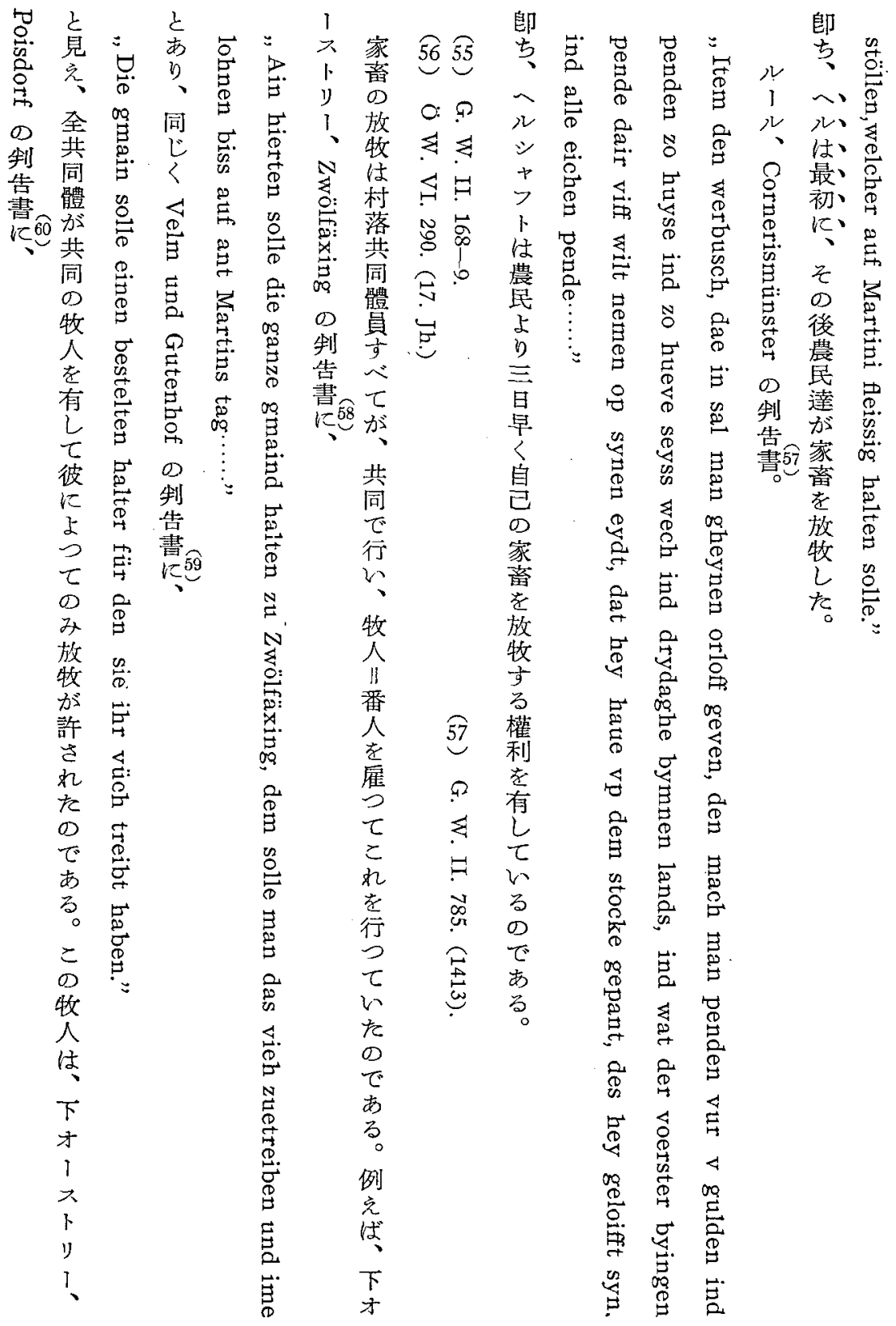


中世後期に於りる Markr echt $\sigma$ 特質

特呑同郎、で然

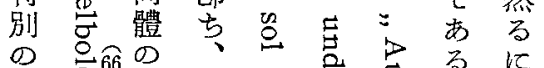

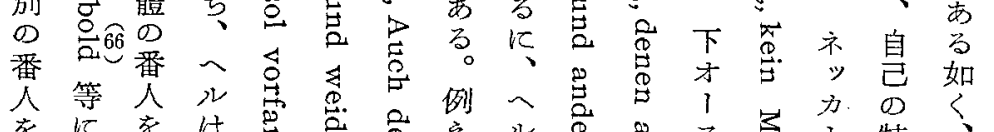

委

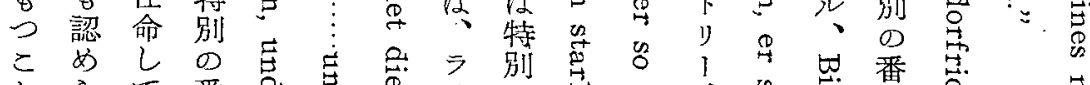

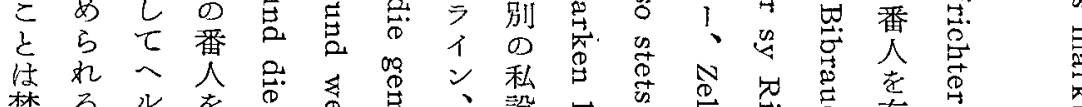

禁省

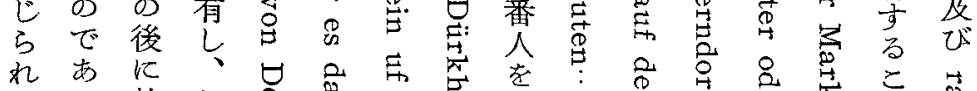

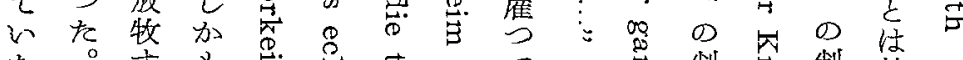

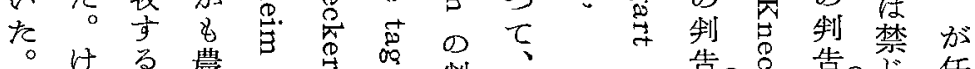

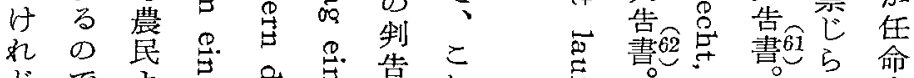

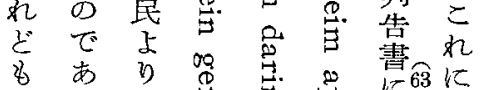

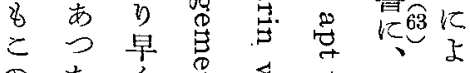

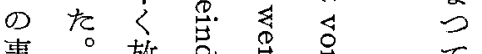

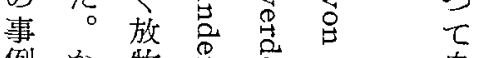

例公牧

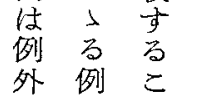

的壮衣

它、㤎

あ

た ダる

ま 士

でク竞

りン有

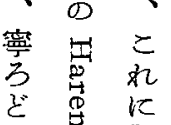

そ $\stackrel{\mathbb{0}}{\Xi}$ に

で $\stackrel{9}{6} 64$

\& $>$ 農

般 $\stackrel{⿱ 乛 龰}{\text { 農 }}$

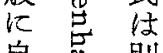

自落别

已 常65

点

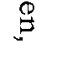

客

-

急

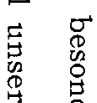

音

D共

$\underset{9}{9}$

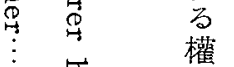

家
蓄
を
放
牧
す
万
權
利
を
蒦
得
た
た
例
が

․ $\stackrel{9}{9}$

$\stackrel{8}{8} \stackrel{9}{9}$

家
畜
を
放
牧
す
る
權
利
蒦
得
た
焦
が

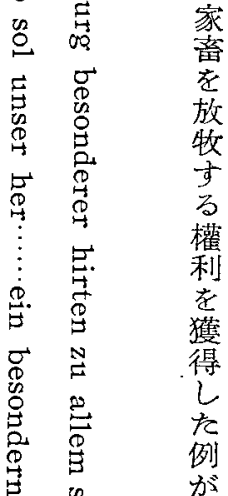

芯

0

若

点意若

兒

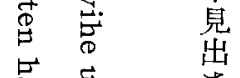

焉蚶点

放

芯 总

tr 和 $\frac{1}{9}$

Е

$\underset{0}{0}$

$\stackrel{N}{\stackrel{5}{~}}$

$\begin{array}{lll}2 & \tau & \vdots \\ 0 & \cdots & 0\end{array}$

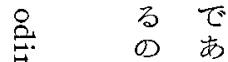

茴

$\stackrel{8}{0}$

疍

艺

$\overrightarrow{7}$

(1)

离 寄.

$\stackrel{8}{3}$

里

占

$\stackrel{2}{\square}$

ڤิ)

$\stackrel{8}{8}$

を゙

そ

怘

管

总

莺

㟔.

窎.

点

용.

$\stackrel{\vec{P}}{\stackrel{P}{9}}$

如 4

故

及

び

そ

$\infty$

役

人

次

次

諸

例

に

示

巳

水

$\tau$

营

w

如

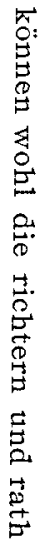




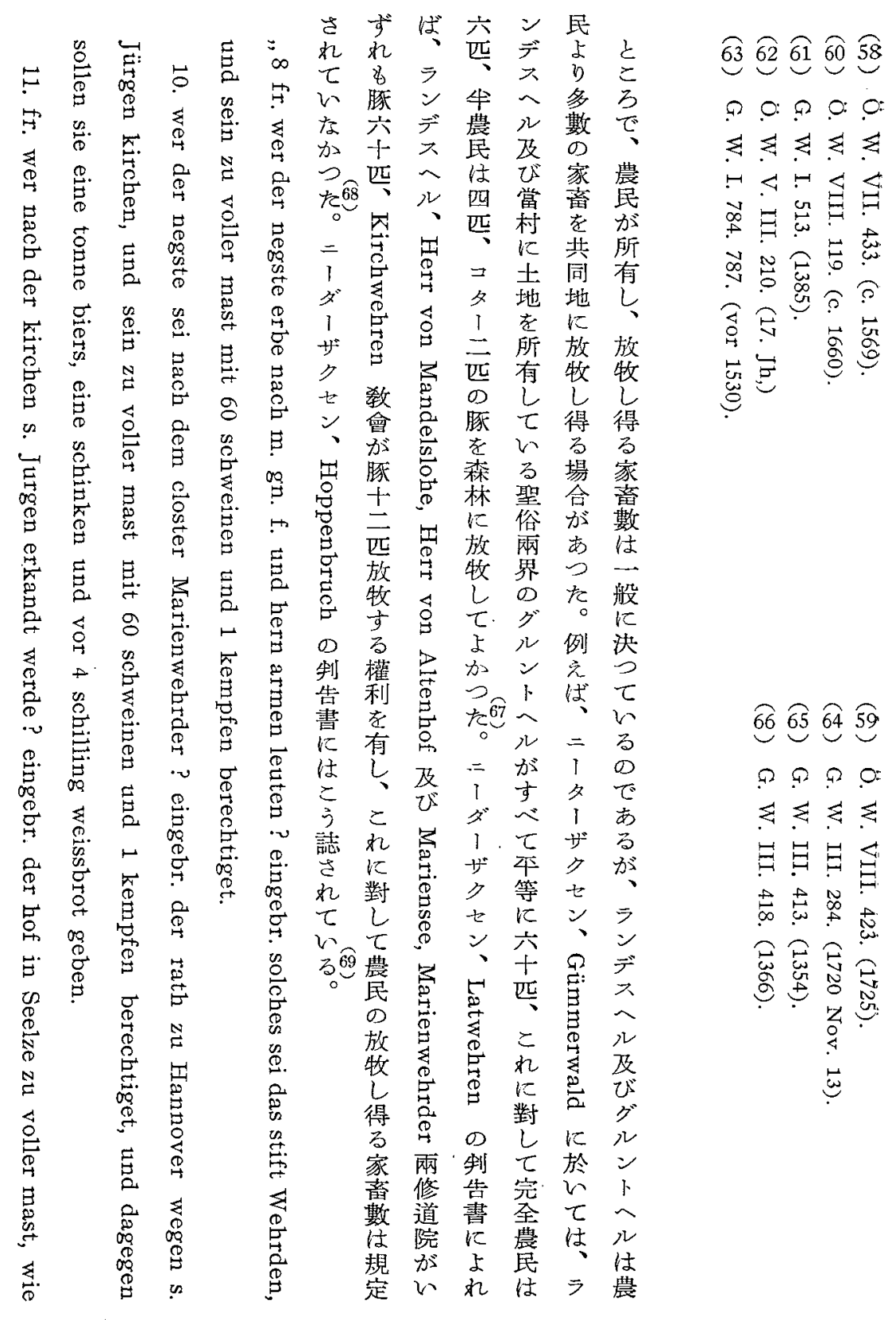


auch zur halben mast mit 30 schweinen, dagegen er nichts zu thun schuldig.

12. fr. wer negst dem hof zu Seelze erkant werde? eingebr. die kirche zu Wehren mit voller mast mit 12 schweinen.

13. fr. wer negst der kirchen zu Wehren erkandt merde? eingebr. die erben wegen des Holtenser landes, und sein dieselben berechtiget, als Christof Fischer zu Gümmer zu voller mast mit 12 schweinen. Hans Crausten zu voller mast mit 8 schw. Jasper Marsburg zu voller mast mit 8 schw. Harman Nohl zu voller mast mit 8 schw. Jürgen Wildhagen mit 2 sch. der pastor zu Seelze mit 4 schw. noch wird der pastor zu voller mast 4 mit schw. erkant, dafür er fische auf die holzung bringet......

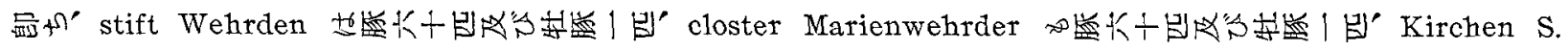

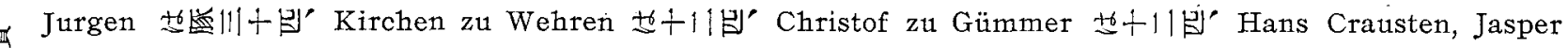

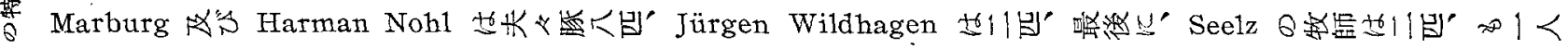

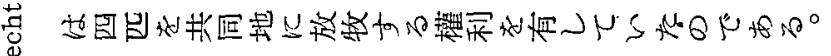

(各) G. W. III. 286. f. (1605).

(g) G. W. III. 289. f. (1605 Sept. 4.).

(ஜ) G. W. III. 293. (1605).

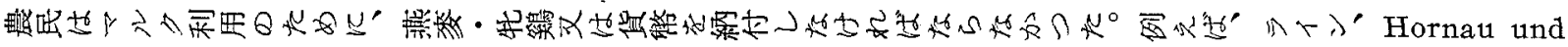
Kelchheim 2 军如艇足,

"der sal geben ein fassnachthun und dri hellere, und darumb nuzẹt ho wașsẹr und weyde, und verzịnset siẹ auch dạmịdẹ:" 


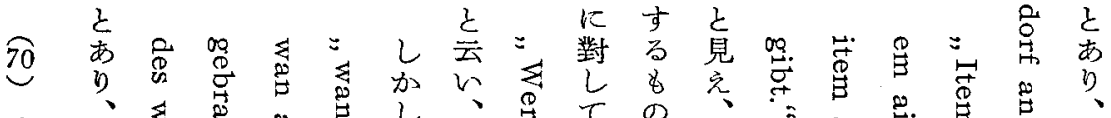

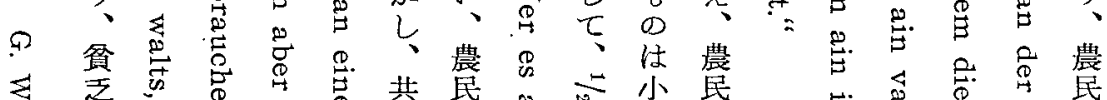
引竞出

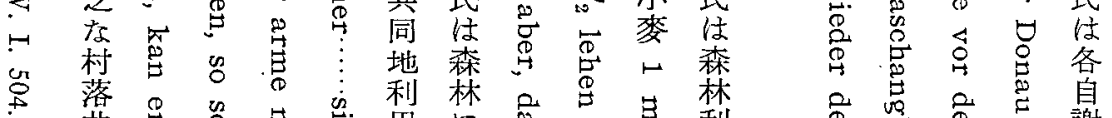

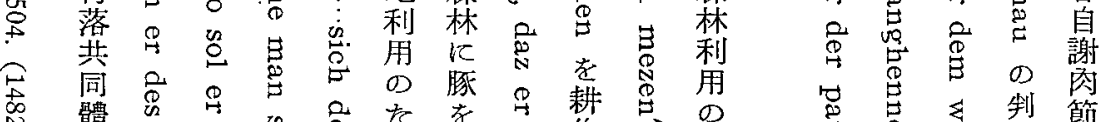

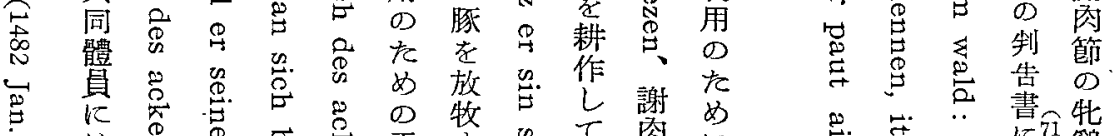

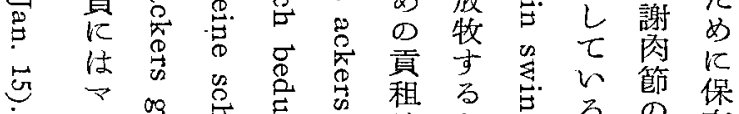

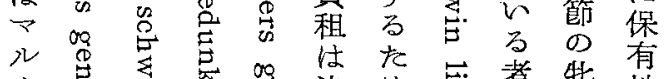

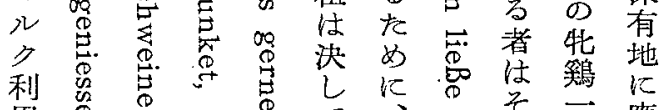
利男 に

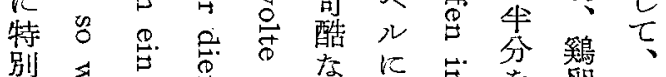

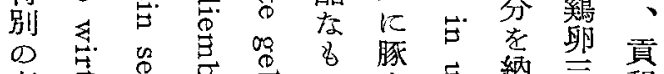
考

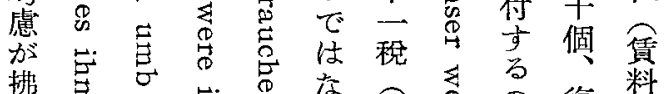

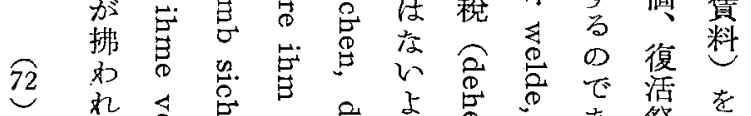
\begin{tabular}{l}
4 \\
\hdashline
\end{tabular}

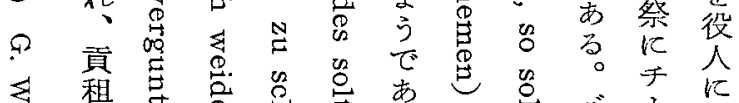

け

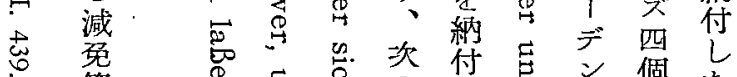

今 等 尽 总

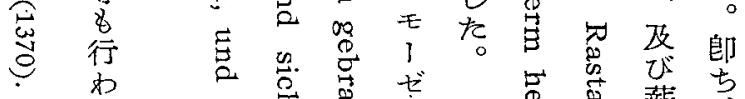

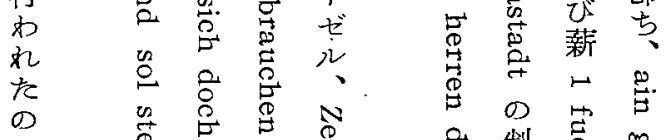

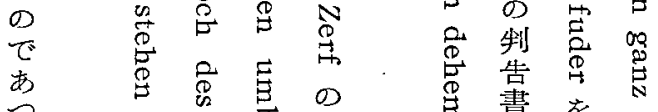

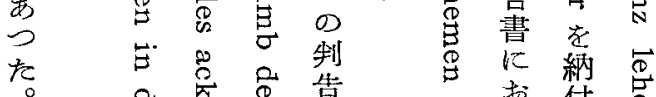

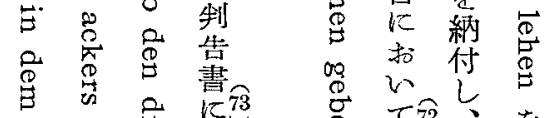


中世後期に於りる Markrecht の特質

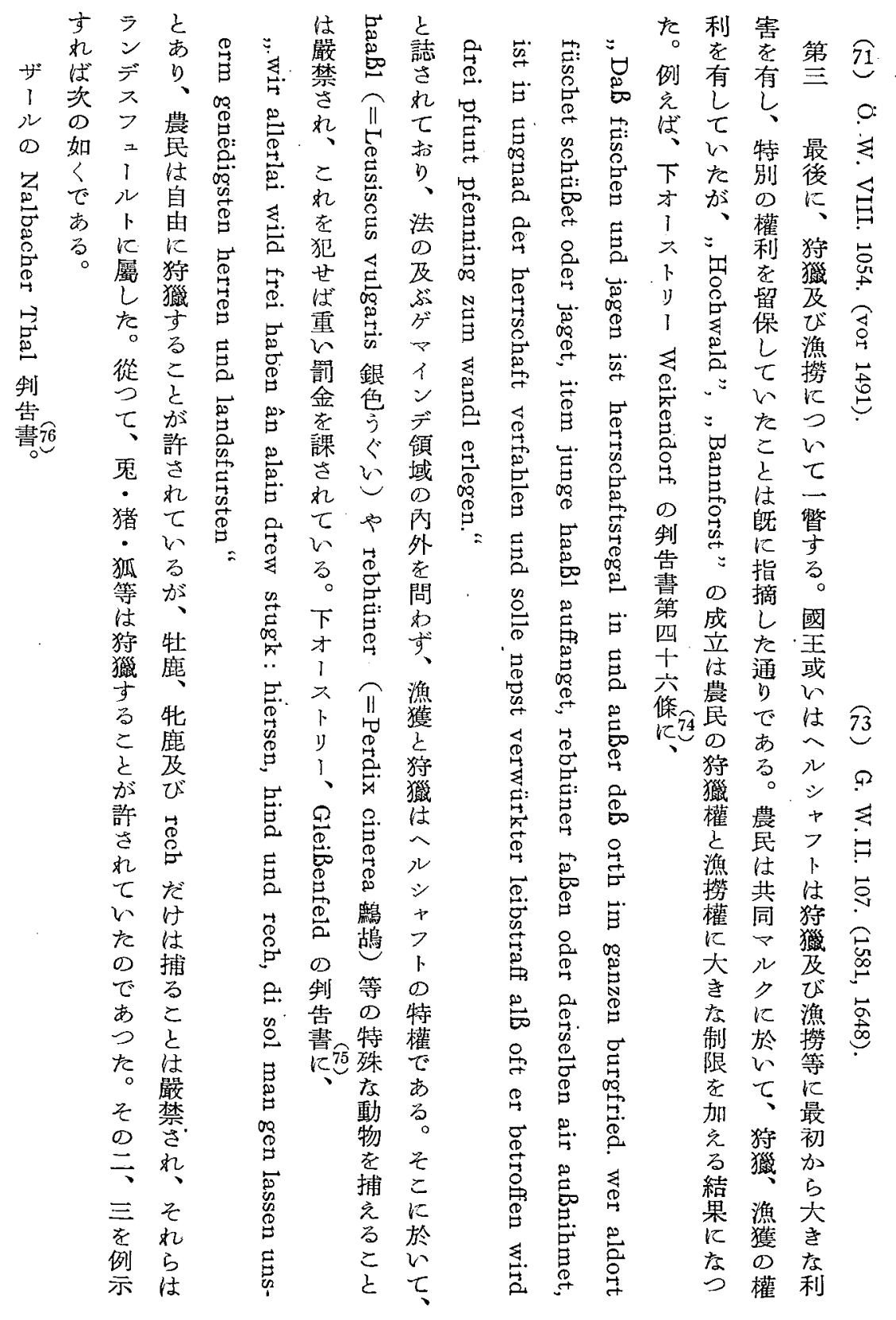




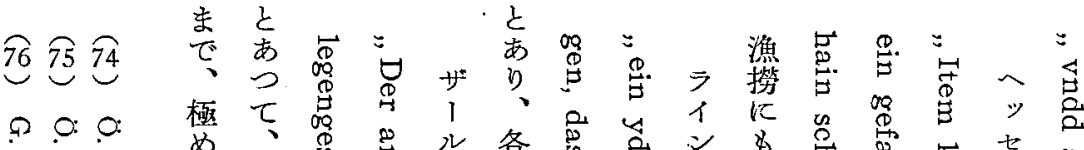

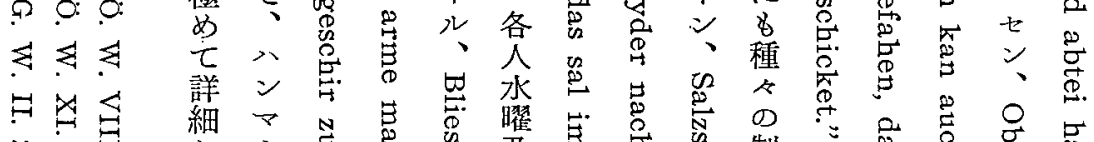

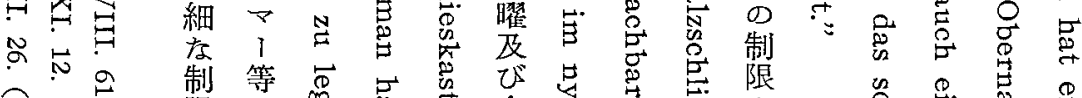

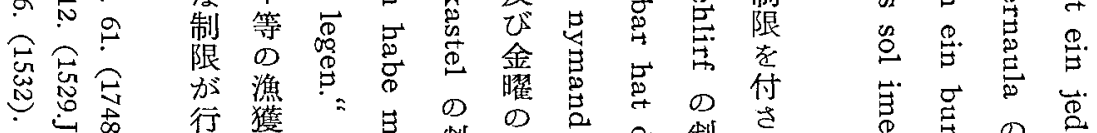

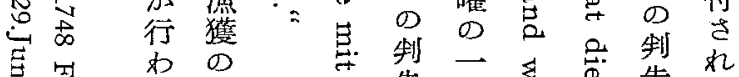

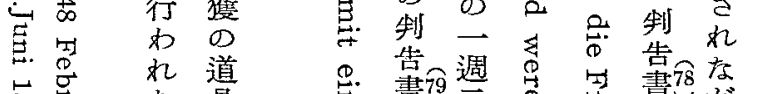

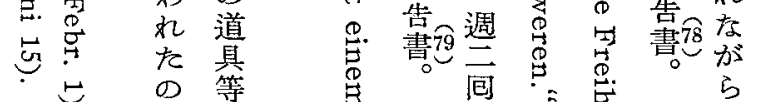

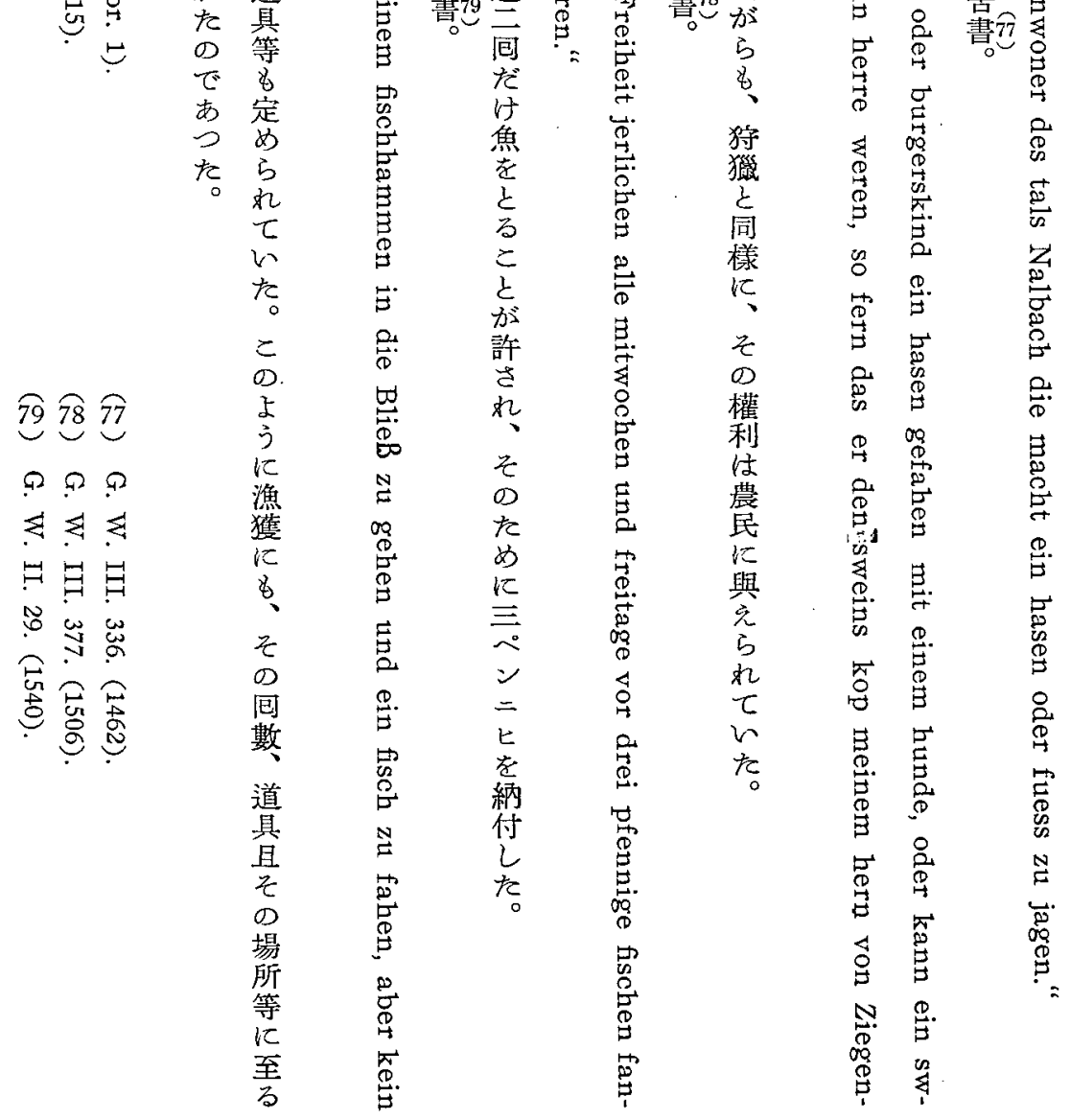


中世後期に於ける Markrecht の特質

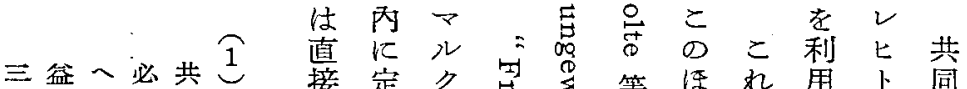

世權の要同

紀 の 參の體 村

江三加古貫落

はつ權るは共

未の、 7 同

だ 權 (二)とＩ體

と利村をつは

扎孝役指二土

ら有人摘を地

のしのし保. 占

權た選た有取

利。舉。し 者

早し人吕

獲雇被加現蹸

得厤選甜貫人

乙华舉成に集

てび權員こ團 招手は机之

占工支、を

ず業び( 耕う

者回)共作性 漸は共同乙格 く士同體てを

中二地總心有 世・用會る ᄂ

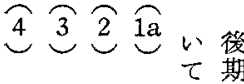

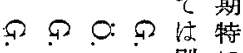

そ之之別に

-上くく六

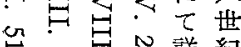

当然吉詩紀

N $N$ 吉諭以

N兄方降

जু

心占宫於

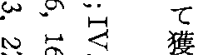

욕 得

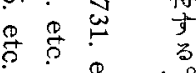

異 当

衣

5

の

點

r

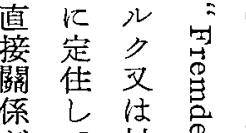

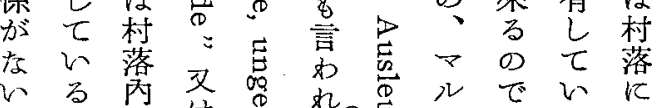

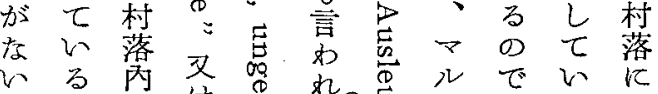

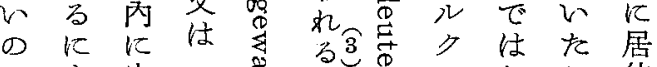

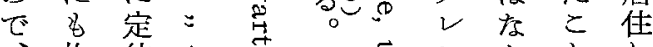

第

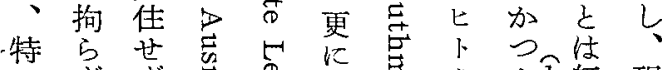

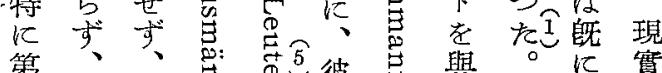

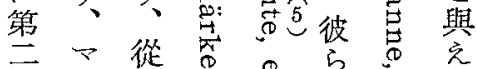

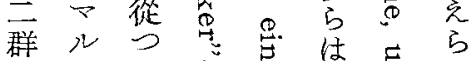

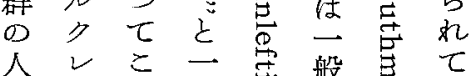

\& 七れ 般

に文原

限を 無 稱

定與關 己

し充係玩

$\tau \zeta$ 或 $\tau$

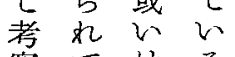

察てはる

し々利诸

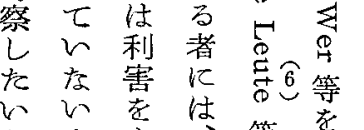

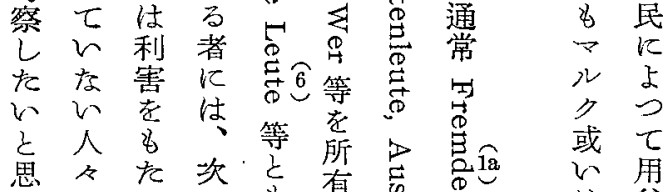

品般

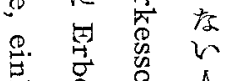

明化

万農 及

か耕び

にに

五從雇

事拲

た 乙 共

的背同

机地

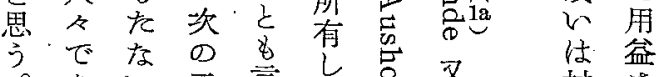

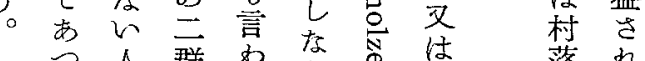

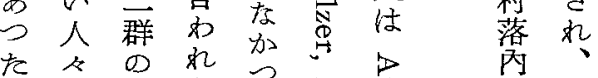

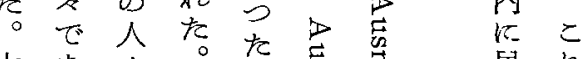

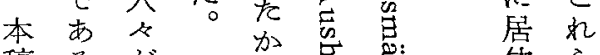

稿るが号官急住ら

で。含

は第 ま

、机

第 穴 る

群 嫦 即

D該 5

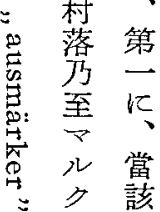

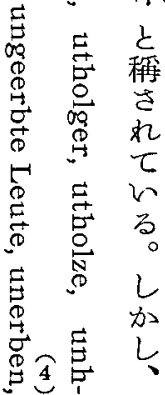

L $\frac{1}{9}$

ᄂ $\tau$

万 0

人村

等

同

て 體

が員

共

同ル

地 ク 


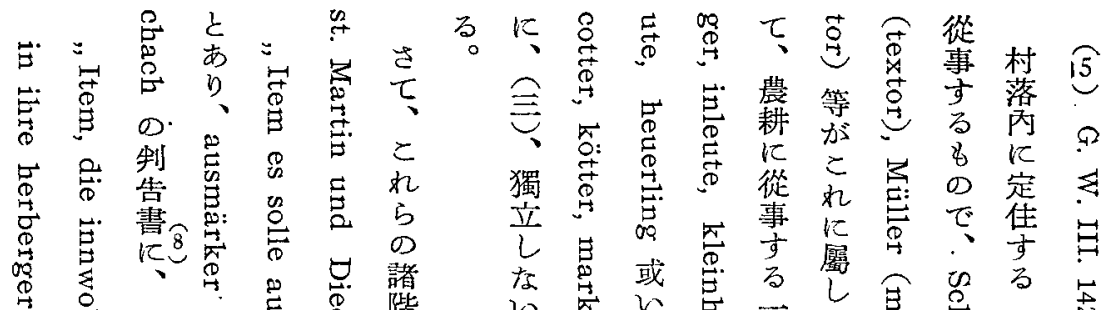

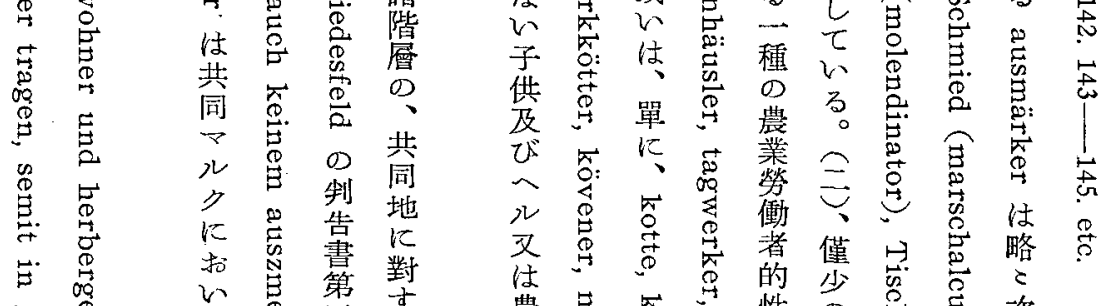

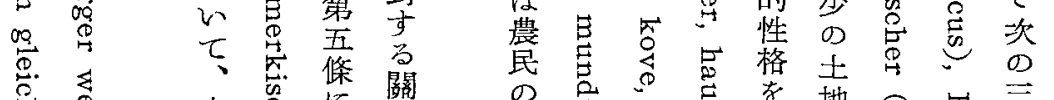

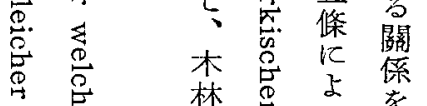

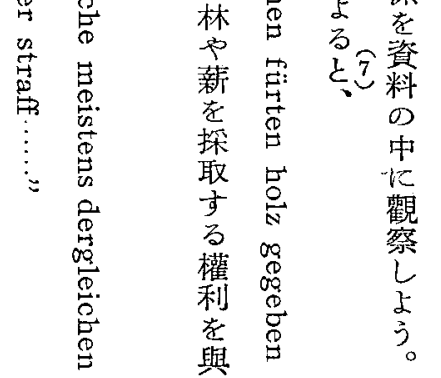

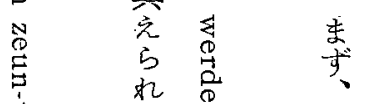

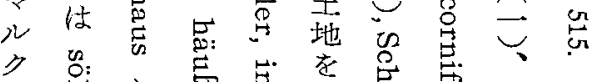

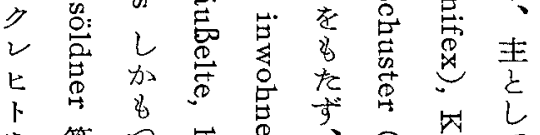

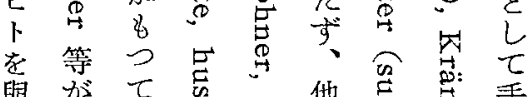

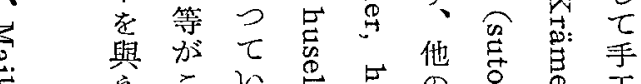

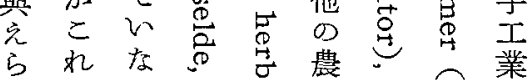

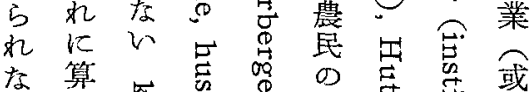

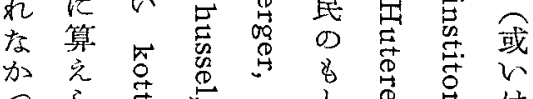

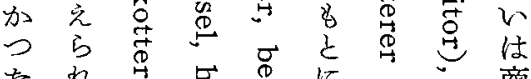

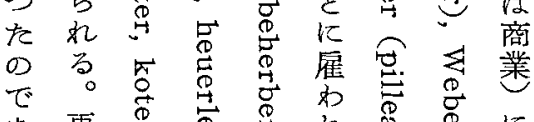
年

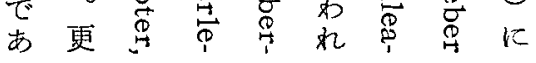


中世後期に於ける Markrecht の特質

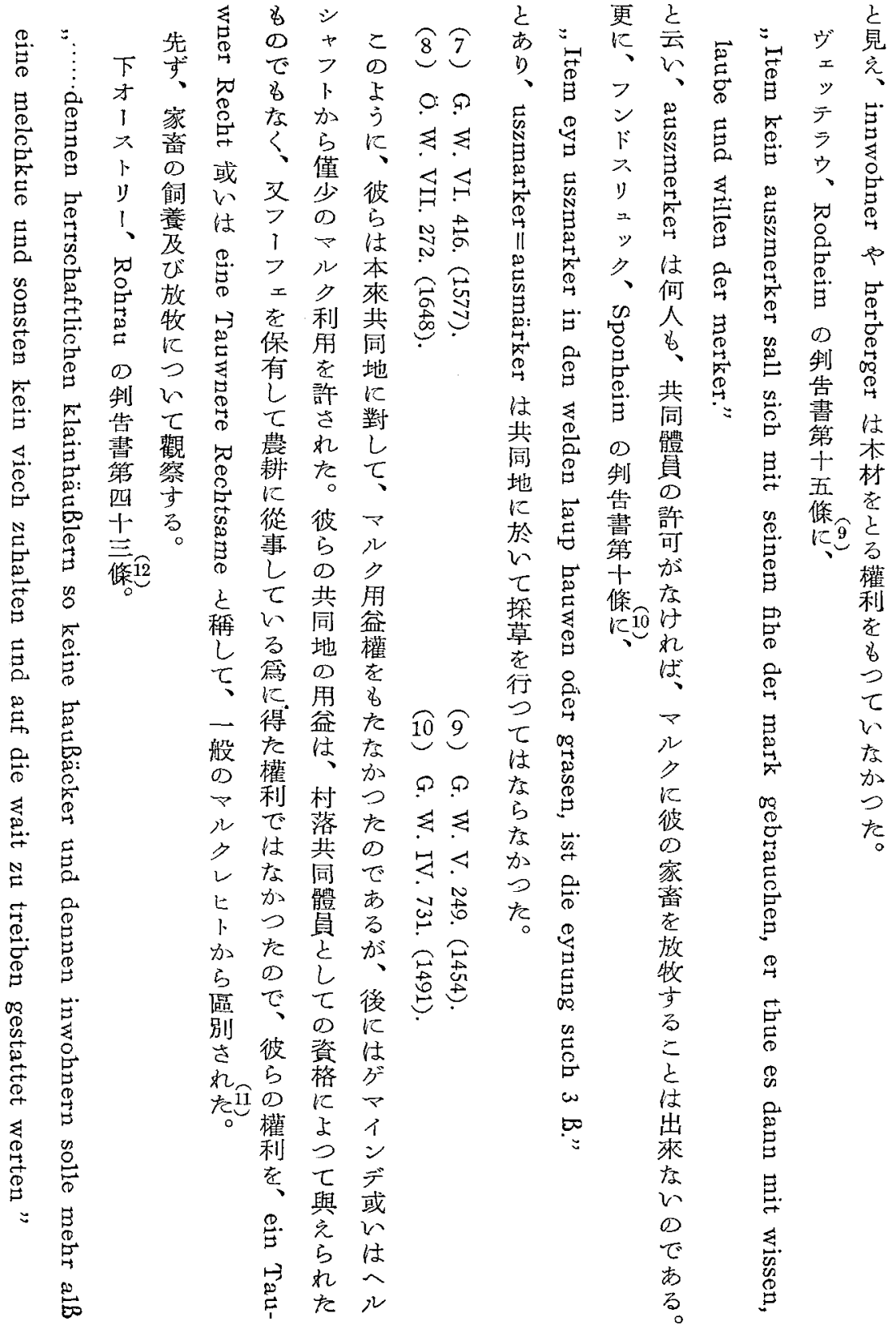




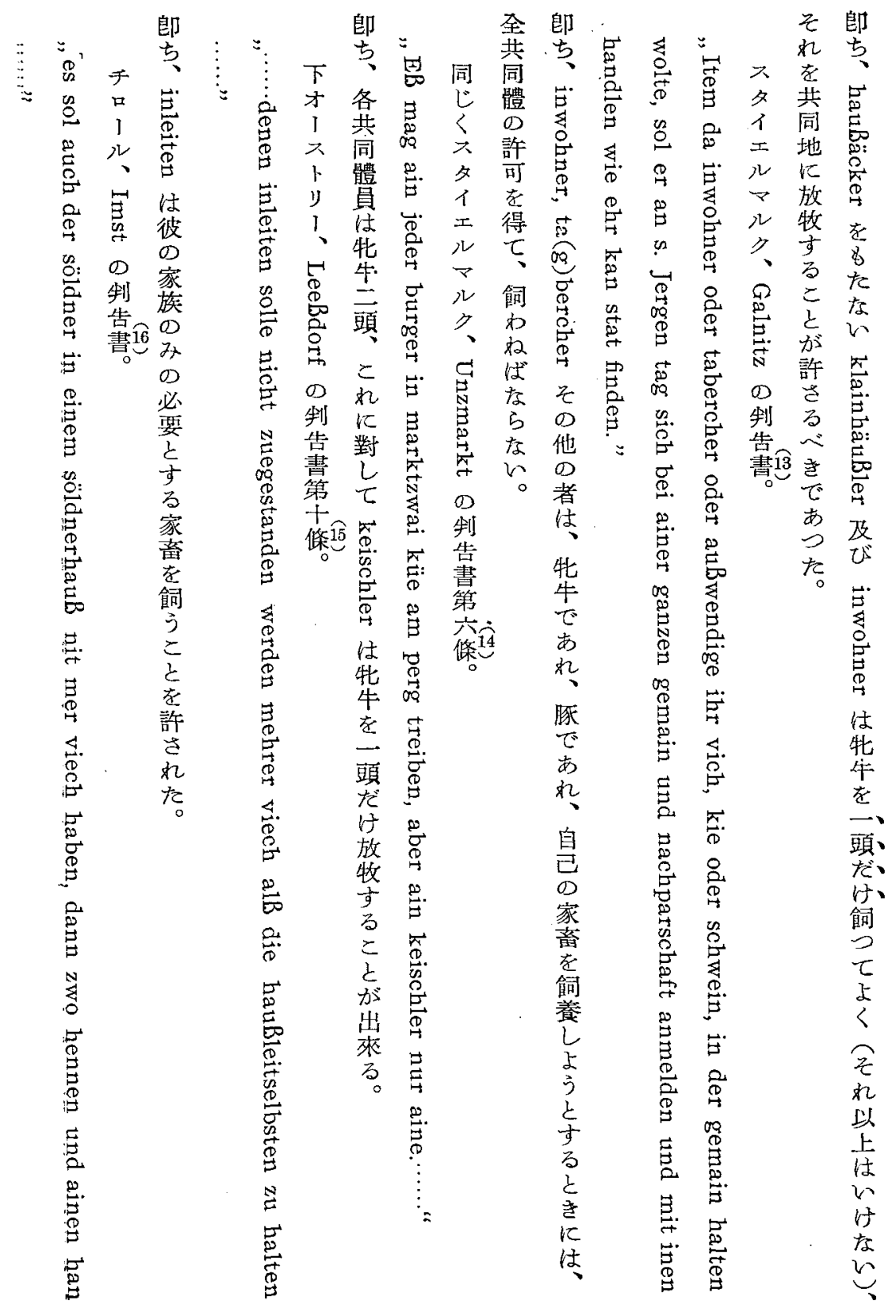


中世後期に於ける Markrecht の特質

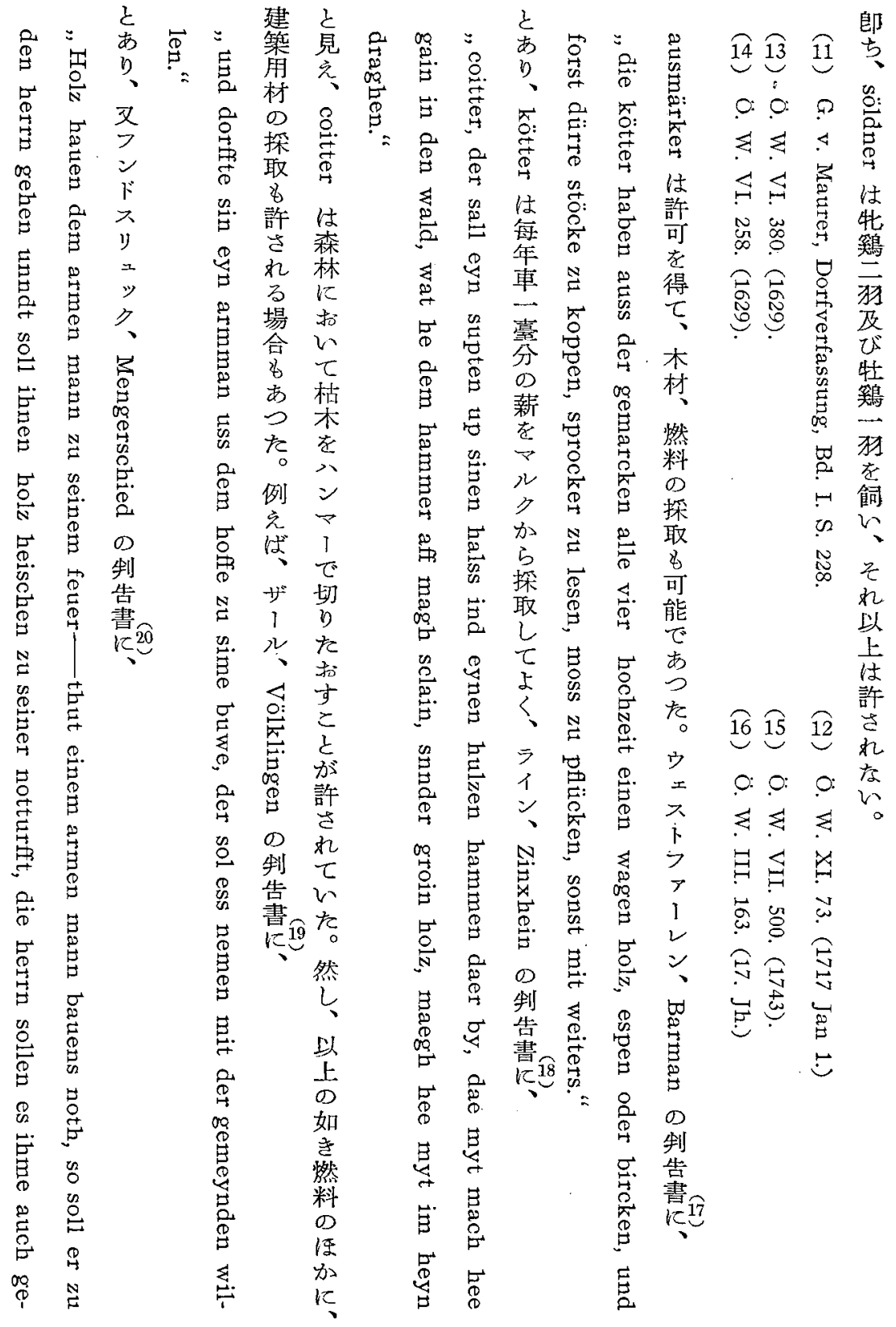




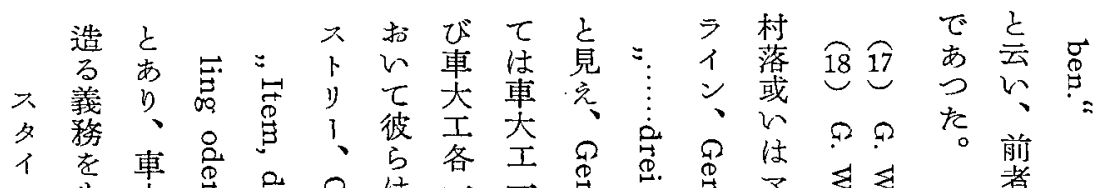

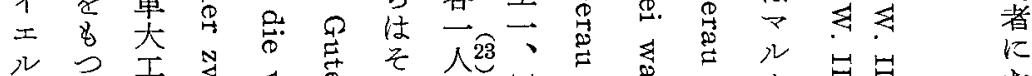

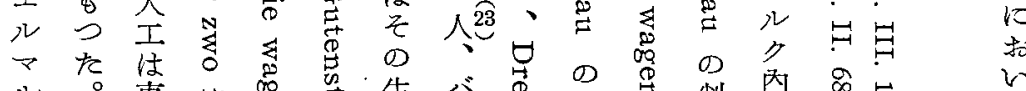

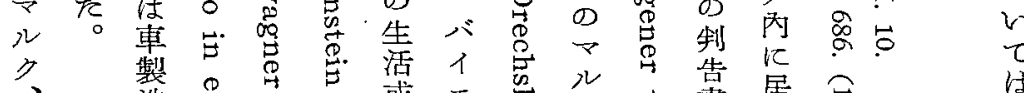

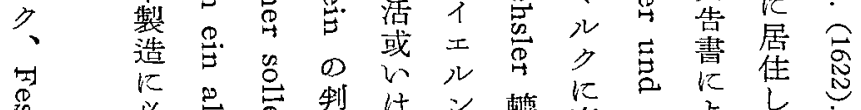

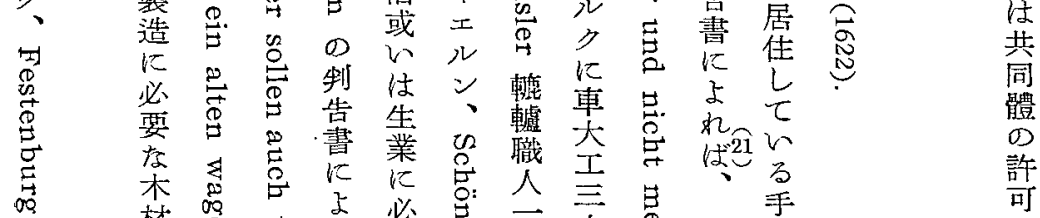

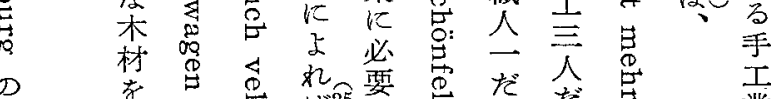

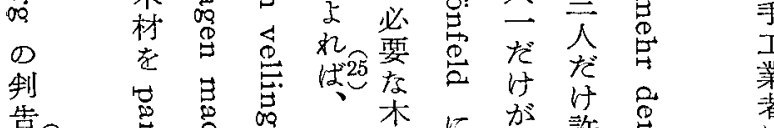

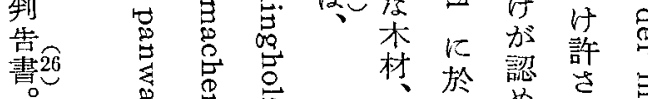

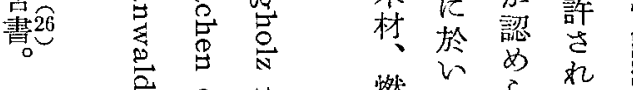

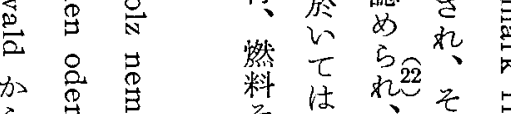

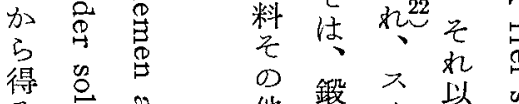

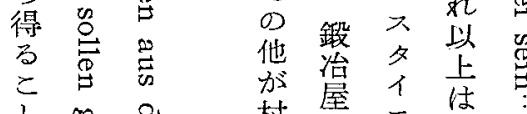

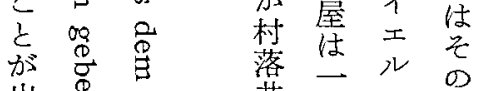

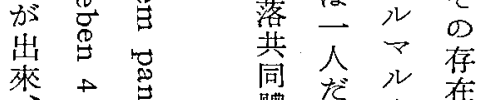

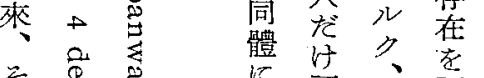

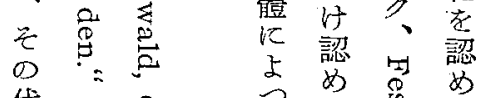

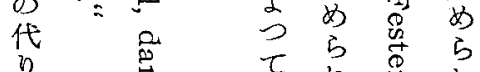

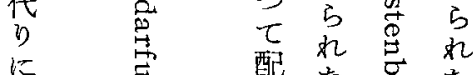

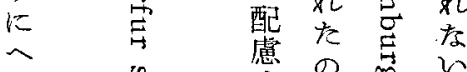

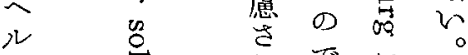

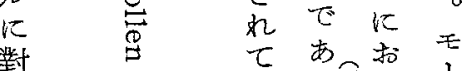

L

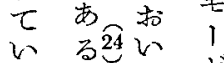

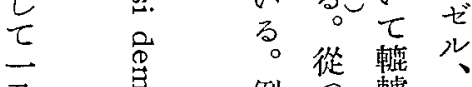

乃

至寔

個

D

車

を

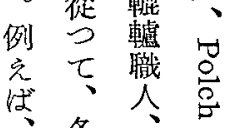

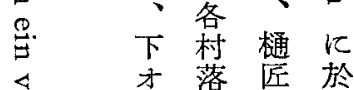

業

䓨

該

村

落

至

2019

x $x$

$\Rightarrow \theta \Omega$

に $\begin{array}{ll}\text { 必 } \\ \text { \& }\end{array}$

要曰ت索

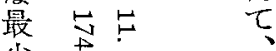

省穴危建

數 㥕㥕 築

k

制

限

e

れ

$\tau$

w

to

例

意
ま

$\tau$

許

を

$\frac{i}{c}$

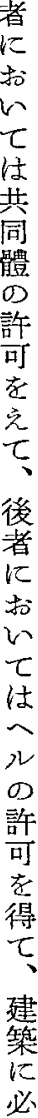

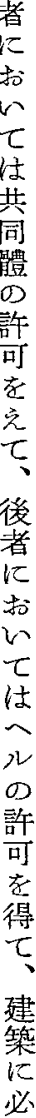

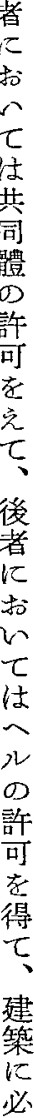

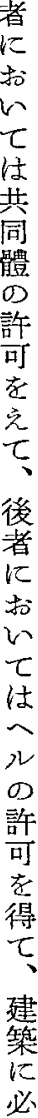

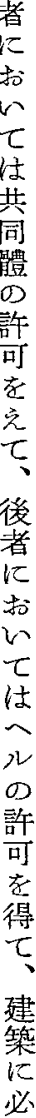

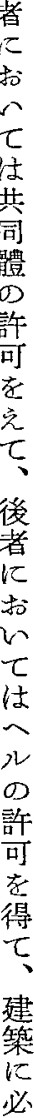

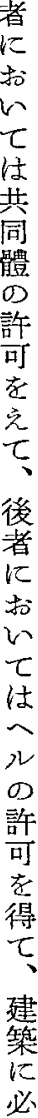

要

な

木

材

を

得

出

來

t

$\infty$ 
中世後期に於ける Markrecht の特質

冶更郎

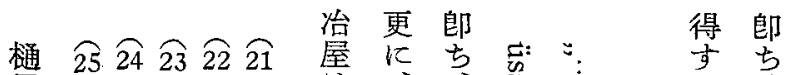

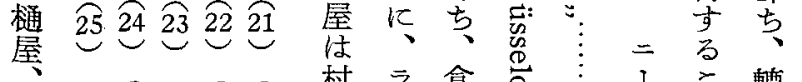

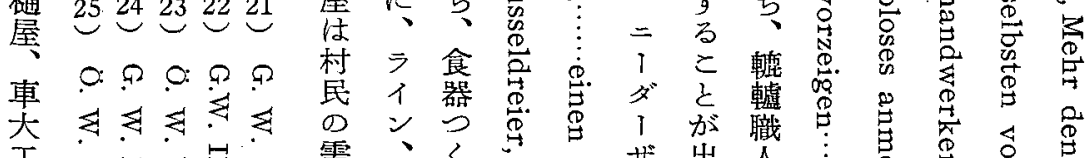

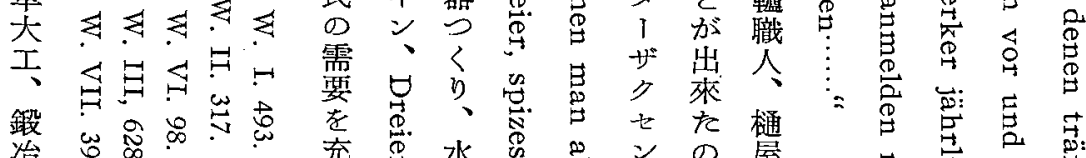

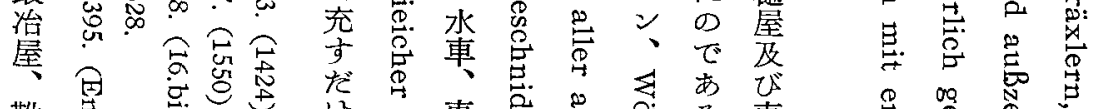

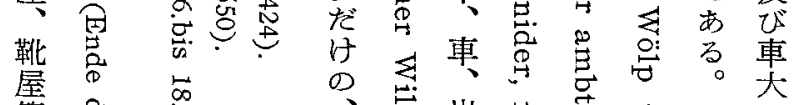

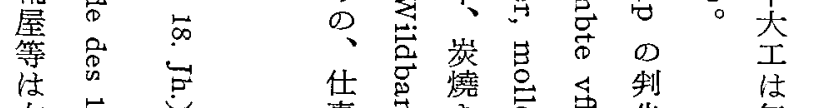

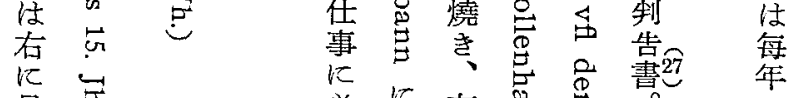

見 异

知

如

必

要

存

材

與

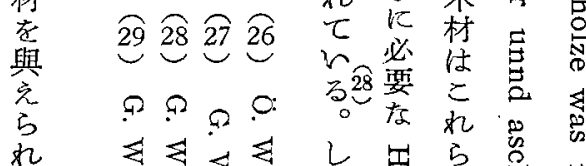

た

で すัٌ

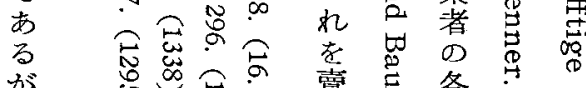

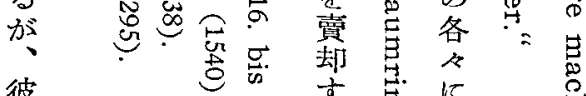

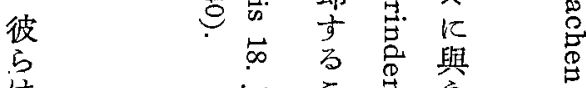

位

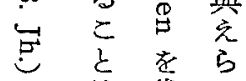

夜

び

村

落

$\infty$

扁

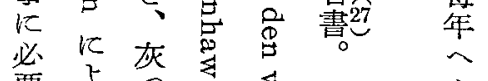

$\sum$ ル

*

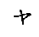

7

1

壁

得

定

O

貨

䌘

䋑

付

L

彼

D

仕

k

必

要

度

材

獲

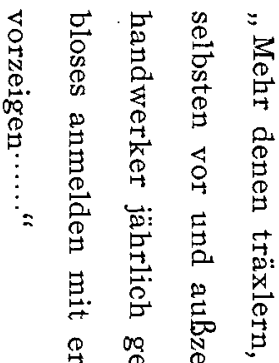

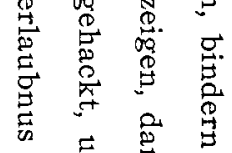

禺

郘 票

它

ㅎ क $\stackrel{0}{9} \stackrel{9}{9}$

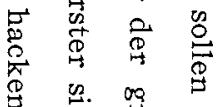

贻 哭

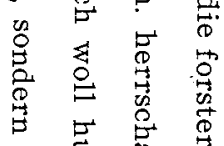

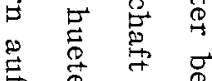

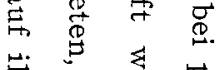

节

总

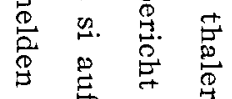

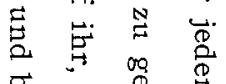

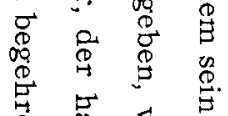

出しき

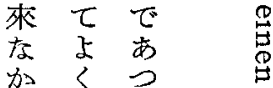

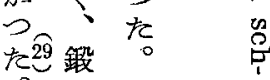


30 生 ル と

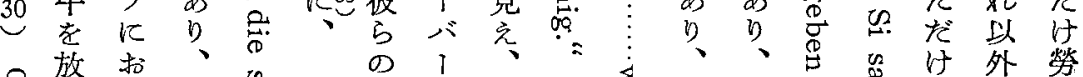
9 放 括

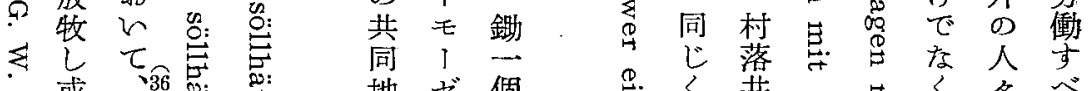

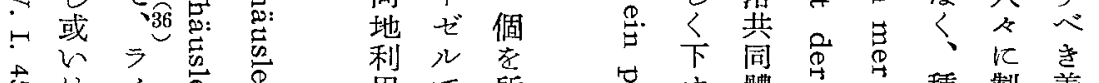

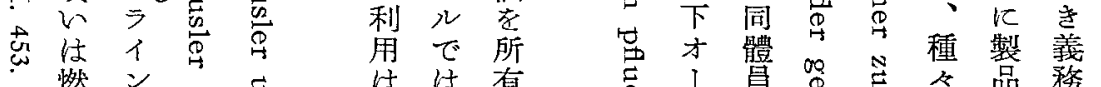

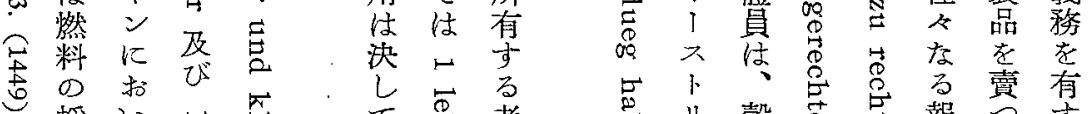

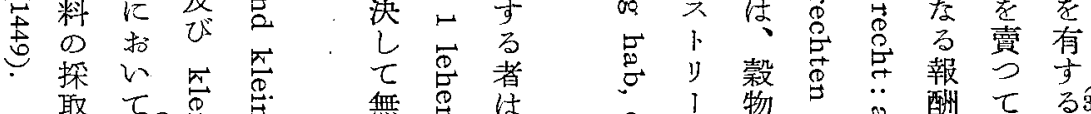

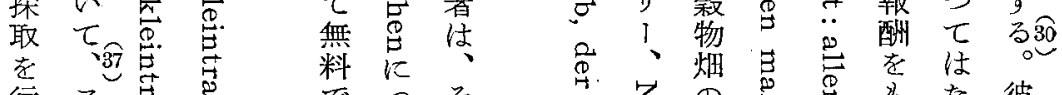
行

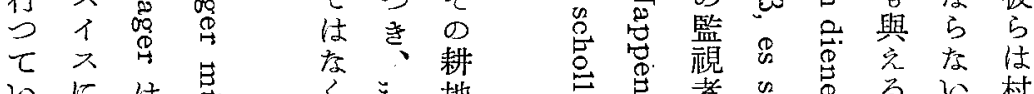

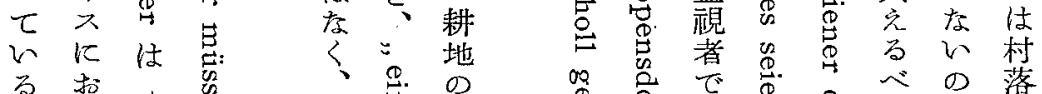

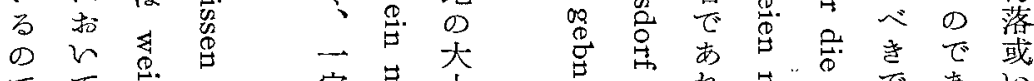

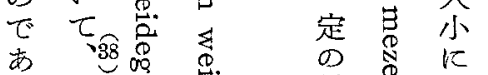
る チ

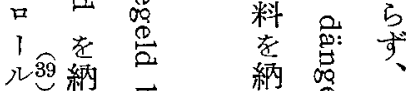

31 ザ

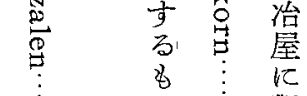

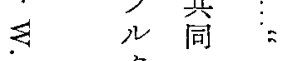

$\leftrightarrow \quad$ K

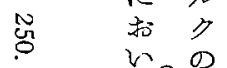

占鸩利

ڤ用

吾 許

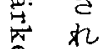

品 $\tau$

は W

筫る

をそ

納 $\infty$

付 他

ᄂ 7
て :

あをて

つ與 小

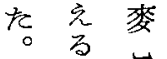

市

チつな高

10 充

ル、光

莟学 常

D

整!

告
例

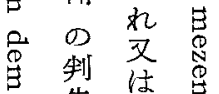

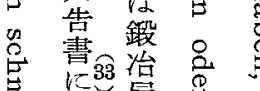

尔であい

㤎あ方は

局つ $\bigcirc$

を村若

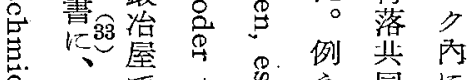

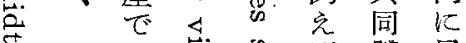

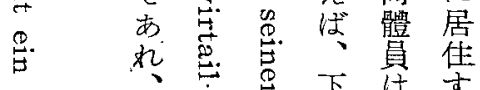

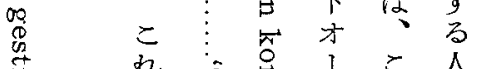

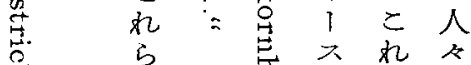

苫 5 点

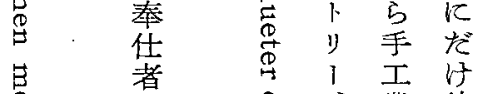

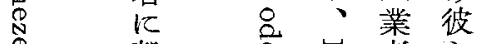

教焉四者

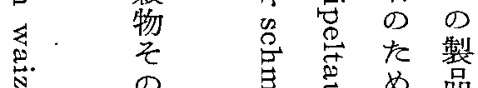

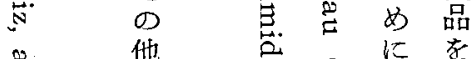

品他 元

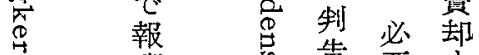

4 酬 量 要 す

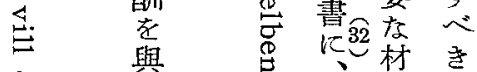

¿ 舆

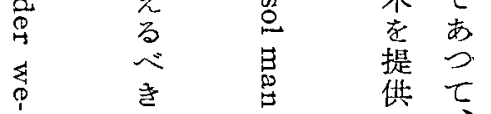


中世後期に於ける Markrecht の特質

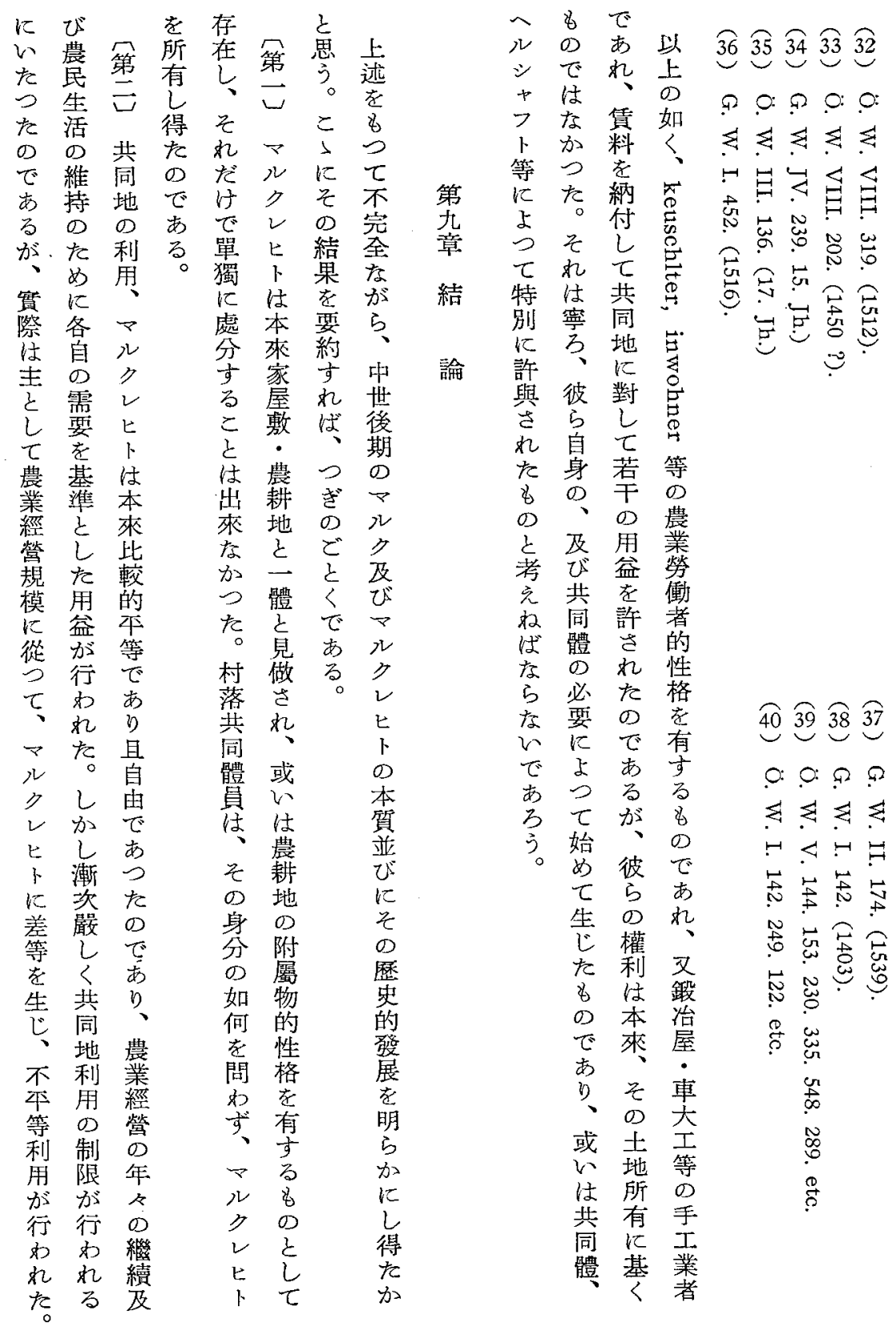




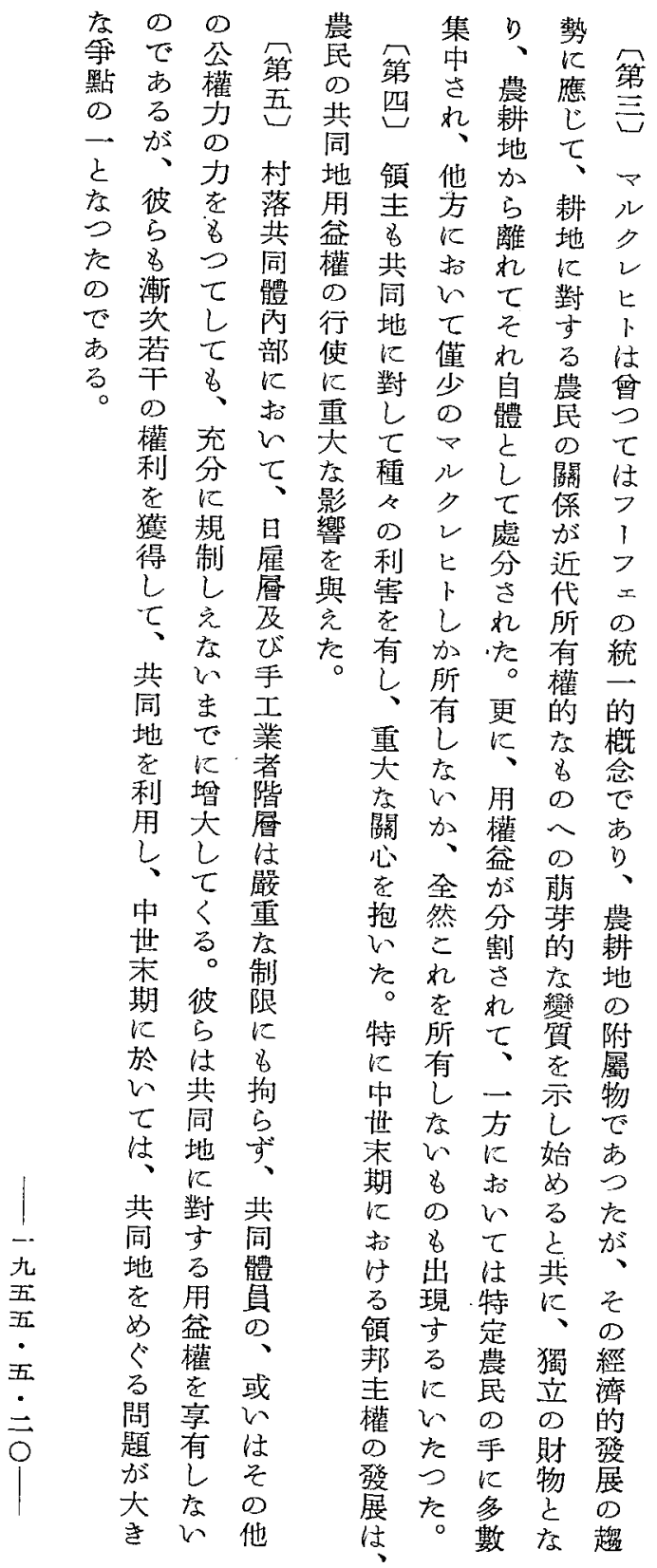




\title{
Das Markrecht im Spätmittelalter
}

- Studien zur deutschen Dorfgemeinde-_-

\author{
by Sakae Itô
}

Die nicht zur Beackerung an die Gemeindeglieder überwiesenen Stücke, kurz alles was nicht getheilt worden war, gehörten zur gemeinen Mark. Nach der Einbringung der Ernte erhielten auch die Äcker Allmendecharakter. Das Markrecht war eine Pertinenz des im markrechtigten Dorfe besessenen Hauses und Hofes. Wohnstatt und Ackerland sind mit dem gehörten. Markrecht als ein Ganzes betrachtet und ebenfalls Hufe genannt worden. Daher hat es immer nur so viele Berechtigungen gegeben, als vollberechtigte Häuser und Höfe in den Dorfschaften vorhanden waren. Mit den Häusern und Höfen hat indessen auch die Anzahl der Markrechten gewechselt.

Die Antheile an der gemeinen Mark und die Markberechtigungen waren ursprünglich in einer und derselben Mark verhältnissmäBig gleich groß. Die Größe der Berechtigung richtet sich wesentlich offenbar, wie die Größe des Besitztums selbst, nach dem Bedürfnisse eines jeden Genossen. Durch spätere Ansiedlungen, VeräuBerungen und Theilungen hat sich jeđoch dieser ursprüngliche Stand der Dinge gänzlich verändert. Dazu kamen nun noch die Veräußerungen und Theilungen der einzelnen Höfe und der mit ihnen getrennten Marktheile in halbe und viertels Were, in ganze, halbe, drittels, viertels und sechstels Gewelden und Rotten, dann die Vereinigung oft sehr vieler Marktheile in einer und derselben Hand, wodurch die ursprüngliche Gleichheit der Berechtigung völlig vernichtet worden ist. Dieser gänzlich veränderte $Z$ ustand führte zu neuen Anordnungen und Einrichtungen. Die Art und Weise der Benutzung der ungetheilten Mark wurde von der Gemeinde genau regulirt, die Größe der Rechtigung nicht mehr nach dem Bedürfnisse eines jeden Genossen, sondern ein für alle Mal bestimmt oder jedes Jahr wieder neu bestim$\mathrm{mt}$, oder auch auf ein bestimmtes Quantum fixirt.

Beisassens Marknutzung war eine bloBe Begünstigung. Erst seit dem 16ten und 17 ten Jahrhundert, hat sich dieses geändert, indem nun in 
manchen Dörfern auch die Kotter und anderen Beisassen als Gemeindegenossen betrachtet worden sind.

\title{
Some Considerations on the Crime of Nukeni 拔荷 (Smuggling)
}

\author{
by Hiroshi Harahuji
}

1. Changes in the Penal Procedures for the Smuggling.

In the firstpart of the Tokugawa period (1666-1717), the government took the policy of terror as regards the crime of Smuggling, and heavy punishments, such as Haritsuke 碟 (crucification) and Gokumon 獄印 (gibbeting of head), were inflicted upon the offenders.

In the second part (1718-1788) of the same period, the offenders were seldom punished with death, and such lighter punishments as Tsuiho 追放 (banishment), Irezumi 入墨 (tattooing), Kessho 關所 (confiscation) were imposed upon the offenders. Measures were also taken to facilitate Sonin 訴人 (information), Jiso 自訴 (self-surrender), Sashiguchi 差口 (secret information), and by exposing thoroughly these different cases of punishment, the government aimed at special prevention.

In the last part of the period, the government returned to its original policy of terror, and people had to smuggle at the risk of their lives, though actually they were not so mercilessly treated as before, when they were captured. But it is noteworthy that in this last period capital punishment was imposed not only on those who committed the crime itself, but also on those who dealt in smuggled articles, and that the off-shore smugglers were punished just as heavily as the in-shore ones.

2. The Penal Regulations concerning Smuggling and the OsadamegakiHyakkajo 御定書百ヶ條 (The Code of 100 Articles)

The penal regulations concerning smuggling can not be found in the Code of 100. Articles, which is to be regarded as the basic code of the Tokugawa Regime. That they were not included in the code is not accidental. The legislators of the Tokugawa Period decided that smuggling had better be left out of the Code. The reason for this decision 